UNIVERSIDADE DE SAO PAULO FACULDADE DE CIENCIAS FARMACEUTICAS

Curso de Pos-Graduaçăo em Fármaco e Medicamentos Área: Produçáo e Controle Farmacuticos

\title{
DESENVOLVIMENTO DE PRODUTOS DERMATOLÓGICOS CONTENDO CORTICOSTERÓDES: AVALIAÇÃO DA LIBERAÇÃO E PENETRAÇÃO TRANSCUTÂNEA POR METODOLOGIA IN VTTRO
}

Maria Vit ória Lopes Badra Bentley

Tese para Obtenção do Orau de Doutor Orfentador: Prof Assoc. Érika Rosa Maria Kedor 
Trabalho realizado nos Laboratórios de Farmacotécnica e Tecnologia Farmacêutica, da Faculdade de Ciências Farmacêuticas de Ribeiráo Preto da Universidade de Săo Paulo, sob financiamento da FAPESP. 
Ao meu pai, MIGUEL e minha irmå RAQUEL.

Ao meu marido GEOFFREY, que sempre me apoiaram, incentivaram e compreenderam. 
A minha mãe, DARCI, por tudo que sempre foi e será para mim.

MÃ

As leis divinas nos reuniram

e através da familia o seu amor

perpetuou em nossos corą̧ðes.

A nossa confiança em DEUS

e a certeza da imortalidade

do Espírito nos dá a confiança

de que "continuamos juntos",

mesmo distantes.

Mãe, a certeza de nos reencontrarmos

nos encoraja para a vida

Nestas palavras, a minha homenagem

de amor, de carinho e de gratida

para sempre. 
À Prof. Assoc. ÉRTKA ROSA MARIA KEDOR que, novamente foi responsável pela minha orientação e também pelo apoio, confiança e amizade. 


\section{AGRADECIMENTOS}

Aos colegas e funcionários das Disciplinas de Farmacotécnica e Tecnologia Farmacêutica, especialmente o Prof. Dr. NEWTON LONDOLFO PEREIRA pelas sugestరes e apoio e a Profa. JULIANA MALDONADO MARCHETTI HERNANDES, pelas sugestőes e apoio.

A minha grande amiga Prof. Dr. PATRICIA MARIA BERARDO GONÇALVES MAIA CAMPOS pela dedicą̧̃o, compreensåo, apoio e incentivo imcomparáveis.

À Prof. Dr. MARIA INESS ROCHA MIRITELLO SANTORO pelo apoio, estímulo e amizade.

Ao Prof Dr. DERMEVAL DE CARVALHO, pelo estímulo, apoio e oportunidade de realizar parte deste trabalho em seu Laboratório.

Ao Prof. Dr. GERALDO MAIA CAMPOS, pela colaboração na realização dos testes estatísticos.

Ao Prof. Dr. JOHN COLLETT, pelas valiosas sugestões.

Aos Professores e funcionários do Laboratório de Toxicologia da Faculdade de Ciências Farmacêuticas de Ribeirão Preto da Universidade de Såo Paulo, pelo apoio nos trabalhos em cromatografia líquida de alta efíciência.

Ao Alexandre Maldonado Marchetti, pela grande colaboração prestada para a digitação deste trabalho.

A FAPESP pelao financiamento e oportunidade de realizaçáo deste trabalho.

A todos que direta ou indiretamente colaboraram para a realizaça deste trabalho. 
MARIA VITÓRIA LOPES BADRA BENTLEY

'DESENVOLVIMENTO DE PRODUTOS DERMATOLÓGICOS CONTENDO CORTICOSTERÓOIDS: AVALIAÇAO DA LIEERAÇAO E PENETRAÇÃO TRANSCUTẤNEA POR METODOLOGIA IN VITRO'.

Comissåo Julgadora

Tese para Obtençáo do Grau de Doutor.

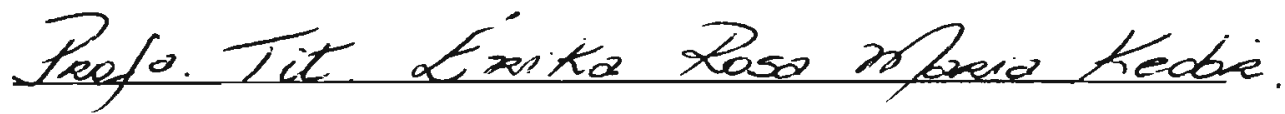
Presidente e Orientador

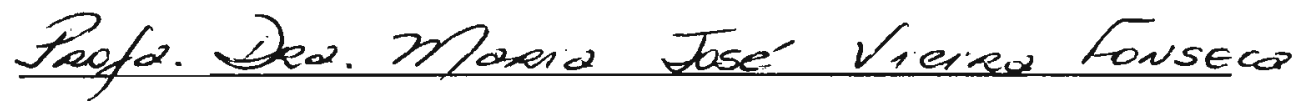
$1^{\circ}$. Examinador

Dof. Tit. Semevial de Carvatho $2^{\circ}$. Examinador

Toufo. Ded. Silvio Staetriets.

$3^{\circ}$. Examinador

Teof. Tit. Tañ thitax telou.

$4^{\circ}$. Examinador

Săo Paulo, Dz de agosto de 1994. 


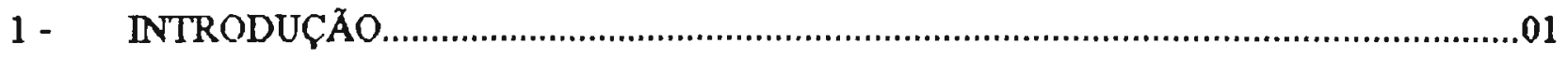

2 - REVISÃO DA LITERATURA

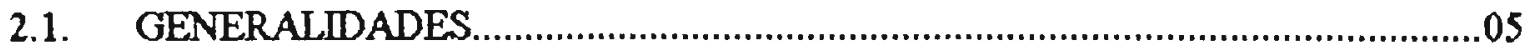

2.2. A PELE COMO VIA DE ADMINISTRAÇÅ DE MEDICAMENTOS..................08

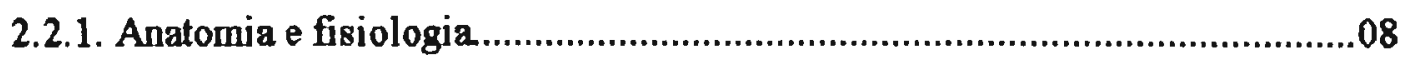

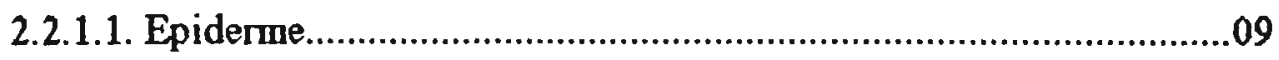

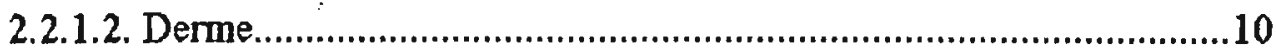

2.2.1.3. Apêndices da pele........................................................................10

2.3. ESTUDOS IN VITRO DE LIBERAÇÃO E PENETRAÇÃO CUTÂNEA

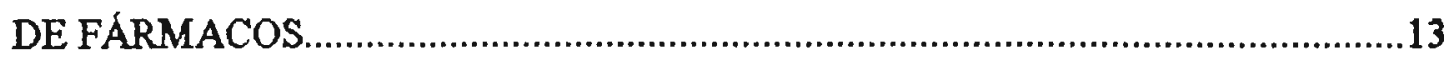

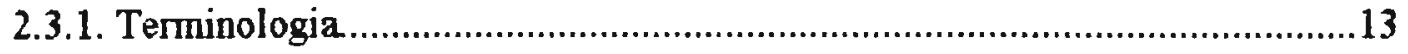

2.3.2. Aparelhos utilizados nos testes in vitro......................................................14

2.3.3. Membranas utilizadas nos estudos de liberaça in vitro de princípios ativos contidos em produtos dermatológicos.

2.3.4. Soluçð̃es receptoras utilizadas nos testes in vitro

2.3.5. Estudos in vitro de liberą̧ão e absorf̧ão cutânea de corticosteróides.........................................................................26

2.4. SUBSTÂNCIAS QUE PROMOVEM A ABSORÇÃO CUTÂNEA ………………......31

2.5. HIDROGÉIS E SUA UTHIZAÇÃO EM SISTEMAS DE LIBERAÇÃO

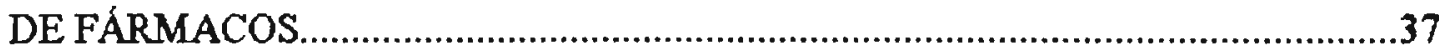

2.6. ANÁLISE DE CORTICOSTERÓIDES POR CROMATOGRAFIA L†QUDA DE ALTA EFICIENCIA (CLAE).........................................................39

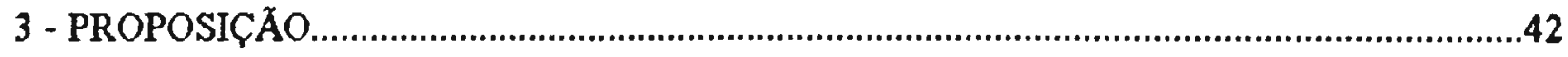

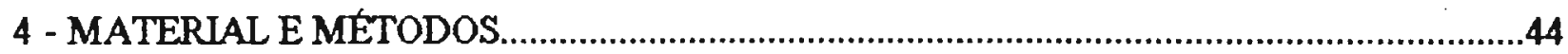

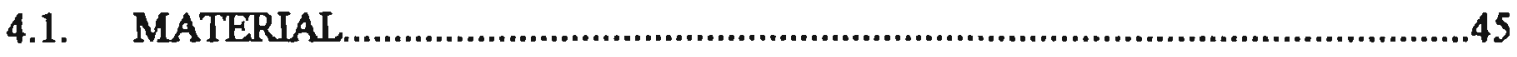

4.1.1. Solventes, reagentes e matérias-primas......................................................45 


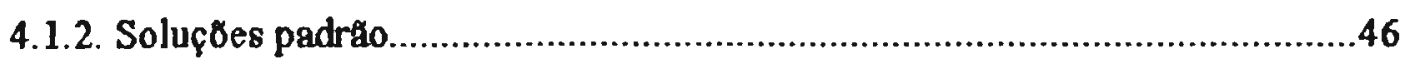

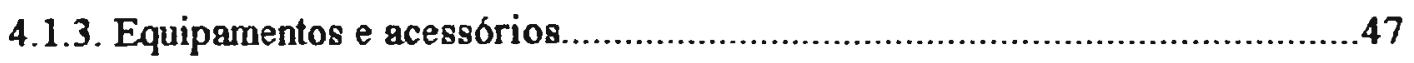

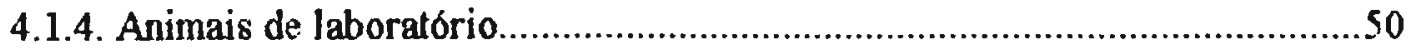

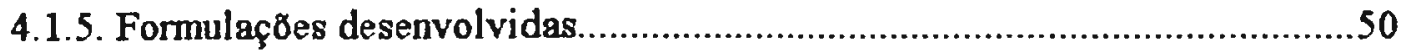

4.1.5.1. Géis hidrófilos contendo uréia .....................................50

4.1.5.2. Géis hidrófilos contendo

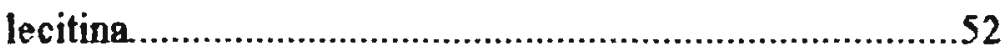

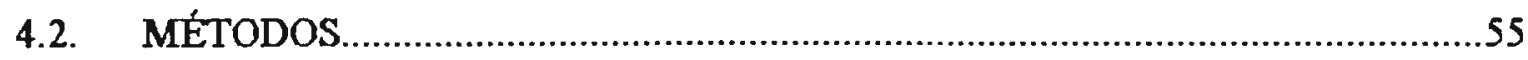

4.2.1. Determiną̧ão das propriedades

fisico-químicas das formulą̧ $\delta$ es............................................................55

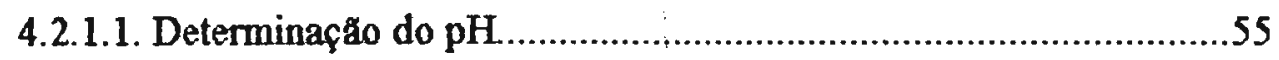

4.2.1.2. Determinaçăo do comportamento reológico. .55

4.2.2. Padronização da metodologia in vitro para os estudos de liberação e penetrafăo transcutânea dos corticosteróides contidos nas formulações desenvolvidas. .57

4.2.2.1. Cêlula de difusão in vitro. 57

4.2.2.2. Solução receptora .62

4.2.2.2. Determiną̧áo do coeficiente de solubilidade dos acetatosde hidrocortisona e de dexametasona, da triamcinolona acetonida e da desonida nas duas fases receptoras. .62

4.2.2.3. Membranas. .63

4.2.3. Padronizaçáo da metodologia analítica para

determinaçáo de corticosteróides por CLAE. 63

4.2.3.1. Condiçסes cromatográficas. .64

4.2.3.2. Procedimentos de extraf̧ð̃ ......................................................65

4.2.3.3. Curva padråo de calibrą̧̃o....................................................65

4.2.3.4. Verificaçáa da eficiência do processo de extraçấdeterminaçáo da recuperação relativa .66 
4.2.3.5. Determinação por CLAE da quantidade de corticosterbides nas formulaçðes desenvolvidas.

4.2.3.6. Determinação por CLAE da quantidade de corticosteroide retida na pele de camundongos sem pêlo nos experimentos in vitro.

4.2.4. Determinaçáo do coeficiente de particão óleo/água dos corticosteróides empregados nas formulaçres.

4.2.5. Condução dos experimentos de liberação e penetração transcutânea in vitro, utilizando a célula de difusáo $\mathrm{n}^{\circ} 3$

4.2.6. Análise dos resultados .70

5.1. DETERMINAÇÃO DAS PROPRIEDADES FÍSICO-QUIMICAS

DAS FORMULAÇÕES. .72

5.1.1. Determinação do $\mathrm{pH}$ .72

5.1.2. Determiną̧ão do comportamento reológico. 73

5.2. PADRONIZAÇÃO DA METODOLOGLA IN VITRO PARA OS ESTUDOS DE LIBERAÇÃO E PENETRAÇÃO PERCUTÂNEA DOS CORTICOSTERÓIDES CONTIDOS NAS

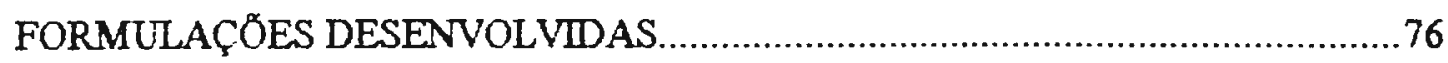

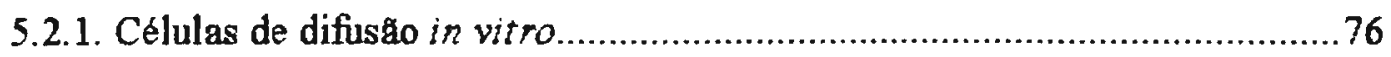

5.2.2. Determinação dos coeficientes de solubilidade.....................................77

5.3. PADRONIZAÇÃO DA METODOLOGIA ANALTIICA PARA

DETERMINAÇÃO DE CORTICOSTERÓDES POR CLAE ........................................78

5.3.1. Condições cromatográficas.............................................................78

5.3.2. Curva padråo de calibração .................................................................. 78

5.3.3. Verificação da eficiência do processo de extraçăo - Determinação da Recuperação Relativa (Rr). .91

5.3.4. Determinąão por CLAE da quantidade de corticosteróides nas 
5.4. DETERMINAÇÃO DO COEFICIENTE DE PARTIÇÃo ÓLEO/ÁGUA DOS CORTICOSTERÓDES EMPREGADOS NAS FORMULAÇO์ES

5.5. EXPERIMENTOS DE LIBERAÇÃO E PENETRAÇÃO TRANSCUTÂNEA IN VITRO, UTLIZANDO A CÉLULA DE DIFUSÅ No 3...................................94

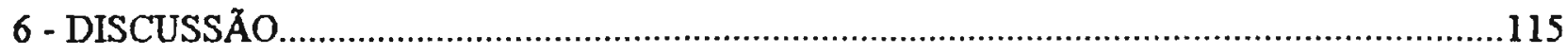

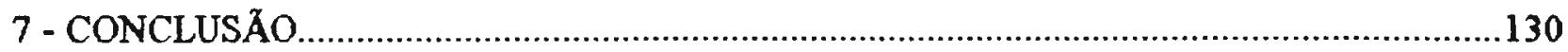

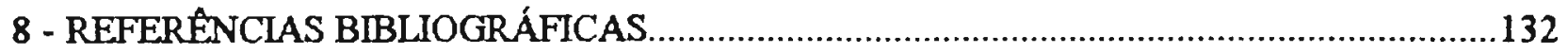

9 - RESUMO

10-SUMMARY 
1 - INTRODUÇAO 
Atualmente a Tecnologia Farmacêutica tem dado especial atençáo à avaliaçăo da eficácia terapêutica do produto acabado. Um produto farmacéutico elegante, estável e com dosagem correta, pode náo proporcionar uma ą̧ão medicamentosa adequada Vários fatores podem ser responsáveis por esta falha na atividade do produto, como por exemplo, os fatores fisiológicos, os quais dependem, na maioria das vezes, do paciente ou do substrato biológico da medicaçáo. Nesta situą̧đo, o farmacêutico formulador năo possui condiçбes de atuar diretamente. Entretanto, existem vários fatores inerentes ao próprio fármaco, a forma farmacêutica, à

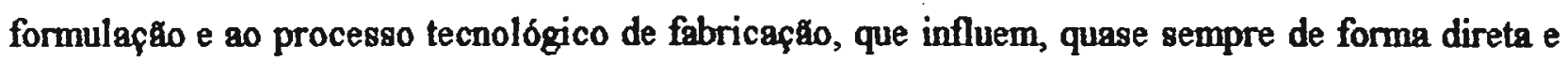
expressiva, na disponibilidade dos medicamentos. Nestes casos, o papel do formulador fundamental e sua responsabilidade indeclinável.

A determinaça, a interpretaça e a modulaçáo da biodisponibilidade dos medicamentos, através de suas formulą̧øes, constituem, na realidade, os principais objetivos de uma ciência galênica denominada Biofarmácia, que está sendo extensamente difundida e praticada entre pesquisadores farmacotécnicos nos últimos anos. A prática da Biofarmácia requer, como premissa fundamental, uma formaça farmacocinética básica, um conhecimento profundo dos mecanismos de liberą̧áo e absorção dos fármacos, bem como da modificą̧̃o destes processos mediante meios fisico-químicos e tecnológicos.

Nos produtos dermatológicos, a formulaçấ que contém o principio-gtivo influencia de maneira significativa na aça final do medicamento. Isto porque, várias interaçôes entre princípio(s) ativo(s) e veículo(s) sáo estabelecidas, interą̧రes estas, que podem modificar, como por exemplo, o coeficiente de partiçáo do(s) färmaco(s) entre o veículo e a pele. Podem, também, alterar a integridade do estrato cómeo e, nesta situą̧áo, a solubilidade do fármaco na camada cómea e/ou a facilidade com o qual ele se difunde através deste tecido, encontram-se afetadas.

A absorçáo de princípios-ativos na pele envolve dois passos consecutivos: a liberaça dessa substancias pelo veículo, e, sua subsequente absorçáo cutanea Os princípiosativos incorporados em veículos inadequados podem ser pouco ou nada absorvidos pela pele. Baseado neste fato, pode-se considerar que os estudos de liberafáo medicamentosa proporcionam 
dados valiosos sobre as particularidades estruturais do velculo e a capacidade deste em liberar os componentes ativos (23).

As caracteristicas de liberafáo de um fármaco a partir de un veículo dermatológico podem ser avaliadas determinando-se o coeficiente de partiçáo bleo/água do fármaco. Entretanto, estudos de liberaça in vitro e in vivo proporcionam dados mais significativos. Durante a fase de desenvolvimento de produtos dermatológicos é adequado empregar procedimentos de liberação in vitro para selecionar veículos e adjuvantes farmacotécnicos, que em conjunto, possam proporcionar uma atividade terapêutica adequada.

Inúmeros sáo os veículos e adjuvantes empregados em dermatologia, porém, a tendência atual desenvolver bases dermatologicas que funcionem como sistemas adequados de liberaçáo de fărmacos (co-polímeros hidrófilos), associados a adjurantes (principalmente alteradores da permeabilidade cutanea) que sejam biocompatíveis com as membranas celulares (5).

Os corticosteroides representam uma fatia expressiva do conjunto de fármacos destinados ao uso dermatológico. Esta classe de substáncias apresenta uma atividade antiinflamatória na pele, e têm sido empregada no tratamento de diversas patologias cutâneas (30).

Baseado nas colocą̧ðes acima e na importância das substáncias corticosteróides em dermatologia, o objetivo do presente trabalho foi desenvolver preparaçes dermatológicas adequadas para a veiculação desses fărmacos, fazendo uso de metodologia in vitro para a avaliaçáo dos parametros: liberaçấo e penetraçáo trancutânea 
2 - REVISÃO DA LTTERATURA 


\subsection{GENERALIDADES}

Desde 1952, os corticosteróides têm ocupado uma posiç̧o de destaque entre as medicą̧ðes usadas para o tratamento tópico de várias doenças cutâneas (107).

De maneira geral, os corticosteróides atuam na pele difundindo-se através das membranas celulares e formando complexos com receptores citoplasmáticos especificos, os quais, por meios bioquímicos estimulam a síntese de várias enzimas responsáveis pelo efeito antiinflamatório dos corticosteróides (35). A Figura 1 mostra as fórmulas estruturais de algumas das substâncias corticosterbides utilizadas topicamente.

Atualmente, encontram-se no mercado cerca de 115 especialidades farmacêuticas de uso tópico contendo corticosteróides isolados ou em associaça com agentes anti-microbianos (28). Os corticosteróides săo utilizados topicamente devido sua potente açấ anti-inflamatória na pele, sendo indicados no tratamento de eczemas, eczemas infantis, dermatite atópica, dermatite de contato, dermatite venerata, dermatite seborréica, neurodermatite, psorlase, intertrigem, etc. Quando presentes em loçoes, cremes, géis ou pomadas é possivel aumentar a penetraça da preparaçáo na pele por meio de um penso oclusivo. A atividade anti-inflamatória na pele é aumentada através de reaf̧̋es de esterificafáo nas posif̧́es 17 ou 21 e pela formaḉo de acetonidas cíclicas nas posiçðes 16 e 17 (69).

Associada ao efeito anti-inflamatório a terapia cutanea com corticosteróides apresenta efeitos colaterais decorrentes da absorçáo sistêmica dessas substâncias, o qual dependerá do verculo utilizado em cada formulação. O uso de pensos oclusivos em grandes áreas de pele, bem como o uso prolongado desses medicamentos ammenta a absorç⿰亻⿻ sistémica dos corticosteróides. A medicą̧áo tópica com corticosteroides na gravidez, deve ser criteriosa e considerada a relą̧áo risco-beneficio, uma vez que estudos em animais mostraram que o uso prolongado e em altas doses podem produzir malformą̧res congênitas no feto $(55,107)$.

Os corticosteróides podem ser metabolisados na pele por meio de enzimas esterases. No entanto, as substancias que contem grupos 17-hidroxi substituídos ou que são fluorados, apresentam maior resistência ao metaboliamo local na pele. Assim, a aplicação repetida dessas 
substâncias produz um depósito acumulativo na pele, resultando em um efeito farmacológico mais duradouro. Em contrapartida, os efeitos colaterais decorrentes da absorf̧áo sistêmica săo exacerbados $(35,55,107)$.

De maneira geral, os corticosteróides utilizados em dermatologia são praticamente insolúveis em água, solúveis em ácool, acetona e cloroformio. A lipossolubilidade é requerida pois substâncias que possuem coeficientes de partição óleo/água elevados apresentan uma boa penetraçáo na pele $(55,69)$. 


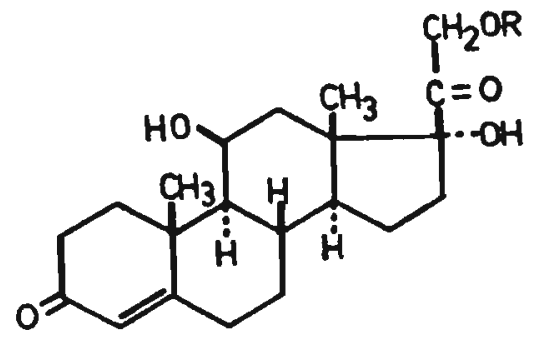

Acetato de Hidrocortisona $\mathrm{R}=-\mathrm{COCH}_{3}$

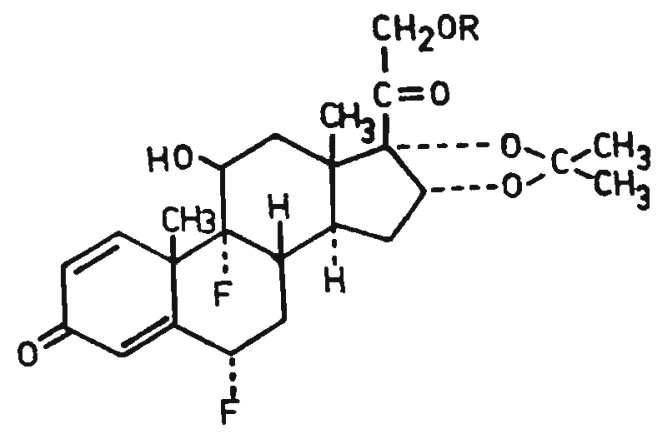

Fluocinolona Acetonida $\mathrm{R}=\mathrm{H}$

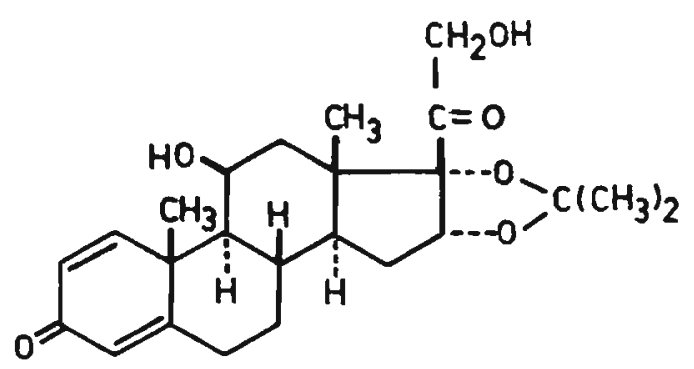

Desonida

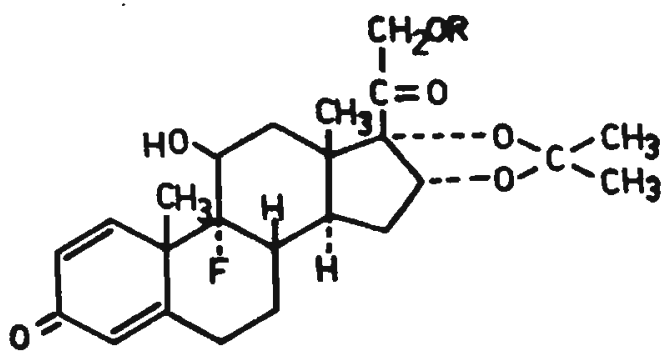

Triamcinolona Acetonida $\mathrm{R}=\mathrm{H}$<smiles>[R2]CC(=O)[C@]1(O)[C@@H](C)C[C@H]2[C@@H]3CCC4=CC(=O)C=C[C@]4(C)[C@@]3(F)[C@H](O)C[C@]21C</smiles>

Acetato de Dexametasona $\mathrm{R}=-\mathrm{COCH}_{3}$<smiles>[R20]CC(=O)[C@@]1(C)[C@@H](C)C[C@H]2[C@@H]3CCC4=CC(=O)C=C[C@]4(C)[C@@]3(F)[C@H](O)C[C@]21C</smiles>

Acetato de Betametasona $\mathrm{R}=\mathrm{COCH}_{3}$ e $\mathrm{R}^{\prime}=\mathrm{H}$

Figura 1: Fórmulas estruturais dos principais corticosteróides utilizados em dermatologia 


\subsection{A PELE COMO VIA DE ADMINISTRAÇÃ DE MEDICAMENTOS}

\subsubsection{Anatomia e nsjologia}

Para que possamos entender e controlar as caracteristicas biofanmacêuticas das formulaçøes dermatológicas é primeiramente necessário conhecer as características da pele.

A pele, o maior orgáo do corpo humano, combina-se com as mucosas do trato respiratório, digestivo e urogenital, formando uma cápsula, que separa as estruturas internas do corpo do ambiente externo. Para um ser humano de $70 \mathrm{~kg}$ tem-se uma ǵrea superficial de pele igual $1,8 \mathrm{~m}^{2}$, sendo que a cada centímetro quadrado podem-ser encontrados 10 folículos pilosos, 12 nervos, 15 glândulas sebáceas, 100 glândulas sudoríparas, 3 vasos sanguineos com $92 \mathrm{~cm}$ total de comprimento, $360 \mathrm{~cm}$ de nervos e $3 \times 10^{6}$ células. Devido ser o tecido do corpo mais acessível, pode-se facilmente danificá-lo mecânica-, química-, e biologicamente e por irradiaçáo (6).

A pele é composta por tecidos distintos, mas mutuamente dependentes: a epiderme celular, estratificada e avascular, e, a derme de tecido conectivo. Abaixo da derme tem-se a camada adiposa subcutânea (hipoderme). A figura 2 mostra as diferentes camadas da pele bem como seus apêndices. 


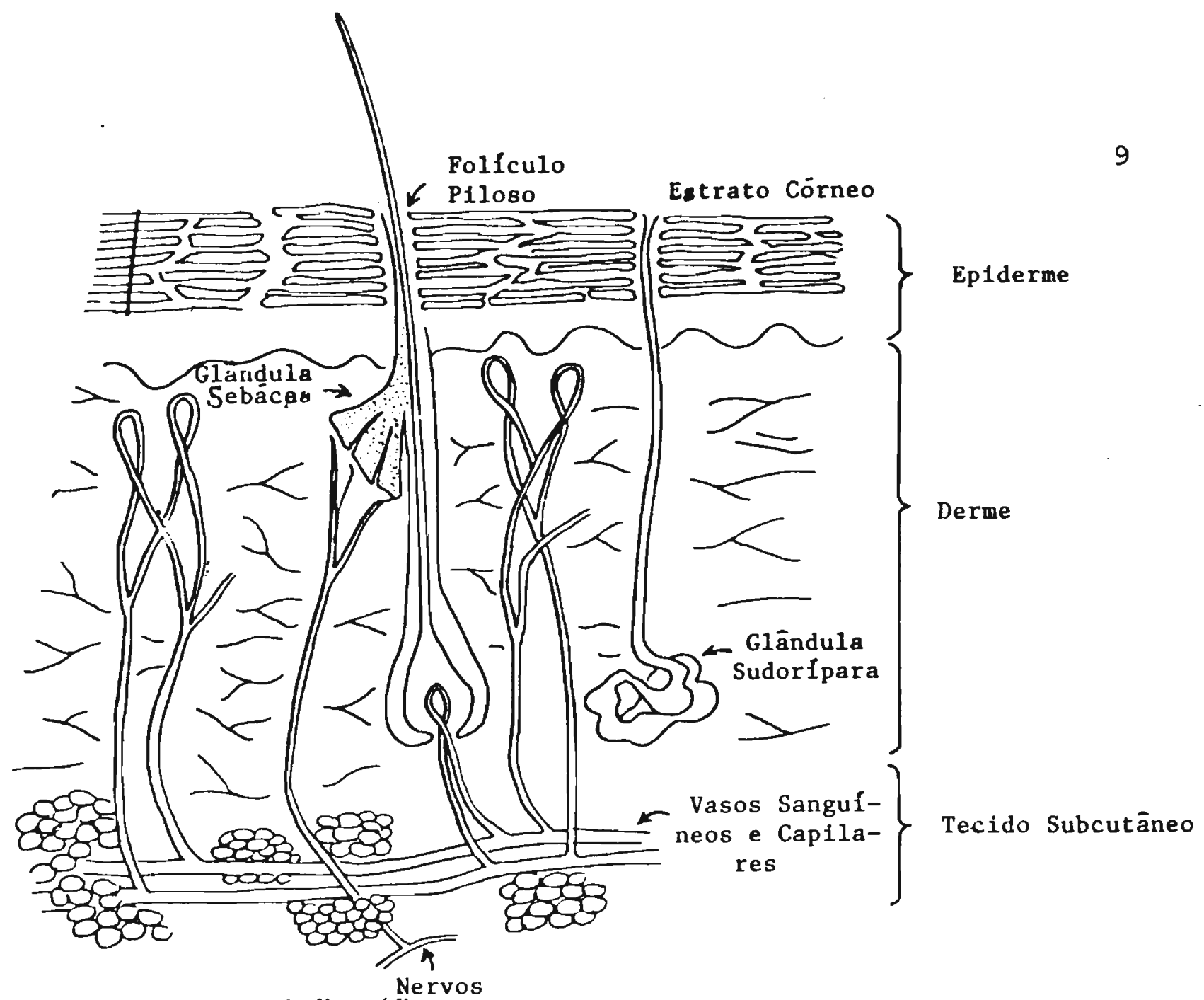

Figura 2: A pele e seus apêndices (6).

\subsubsection{Epiderme}

A espessura da epiderme varia de acordo com a regiăo do corpo, sendo mais espessa nas palmas das máos e planta dos pés e mais fina ao redor dos olhos. Encontra-se estratificada, pela ordem na qual se forma, nas seguintes camadas (6):

- Camada basal: onde ocorre constantes mitoses para renovar a epiderme. Localiza-se na junçáo dermo-epidermal.

- Estrato germinativo: onde se observam alteraçoes morfológicas e histoquímicas nas células. Tem-se nesta camada os queratinócitos. 
- Estrato granuloso: onde os queratinócitos produzem granulos de queratohialina, precursores da queratina

- Estrato lácido: presente nas palmas das mãos e planta dos pés. Såo regioes pobres em hialina formando uma camada fina e translúcida logo acima do estrato granuloso.

- Estrato cómeo: constitui a camada mais superficial da epiderme, onde as células

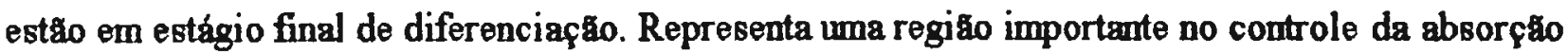
cutânea de farmacos. A permeabilidade seletiva desta estrutura apresenta-se como tema central em muitos aspectos biofarmacêuticos de medicamentos tópicos. E no estrato córneo que se tem o efeito reservatónio, isto é, algumas substâncias (principalmente corticosteróides) podem ficar localizadas na forma de depósitos nesta regiáo da epiderme $(77,99)$.

\subsubsection{Derme}

A derme representa uma camada mais espessa que a epiderme. Consiste basicamente de uma matriz de tecido conectivo formado por proteínas fibrosas ( $75 \%$ de colágeno, $4 \%$ de elastina, 0,4\% de reticulina) emvolvidas em mucopolissacarideo. Encontram-se na derme os vasos sanguíneos e linfáticos, nervos e os apêndices cutaneos.

\subsubsection{Apêndices da pele}

A regiá da derme e epiderme acomodam vários apêndices como: glândulas sebáceas e sudoríparas (écrinas e apócrinas) folículos pilosos e unhas.

A pele como um todo desempenha várias funçðes, como (6):

a) Funçăo mecânica: envolver fluidos e tecidos do corpo;

b) Funçá barreira: proteger contra a entrada de microorganismos, substáncias químicas, radiąåo, calor e choque mecánico. 
c) Receber estímulos externos: tato, calor, dor,

d) Regular a temperatura corpórea;

e) Sintetizar e metabolizar substâncias;

D Secretar substâncias;

g) Regular a pressåo sanguínea

No desenvolvimento de produtos dermatológicos, a funçăo da pele que merece maior atençăo é a funçদ̆ barreira, una vez que, na maioria das vezes, várias substâncias medicamentosas são veiculadas no local. A pele e seus apêndices regulam a entrada de substâncias externas no organismo. A penetraf̧ão de färmacos na pele pode ocorrer por duas vias (6):

- Via transepidérmica: representada pela via intra e intercelular. $O$ estrato córneo representa principal barreira contra a entrada de substâncias;

- Via apendices: representada pelo folículo pilossebáceo e poros.

Para uma dada substáncia penetrar na pele é necessário que primeiramente ocorra a difusão e liberação da mesma do veículo bem como sua partição nas diversas camadas da pele. As figuras 3 e 4 mostran, esquematicamente, as rotas de penetraçåo e locais de atuafáo de várias classes de substâncias utilizadas em dermatologia $(6,105)$.

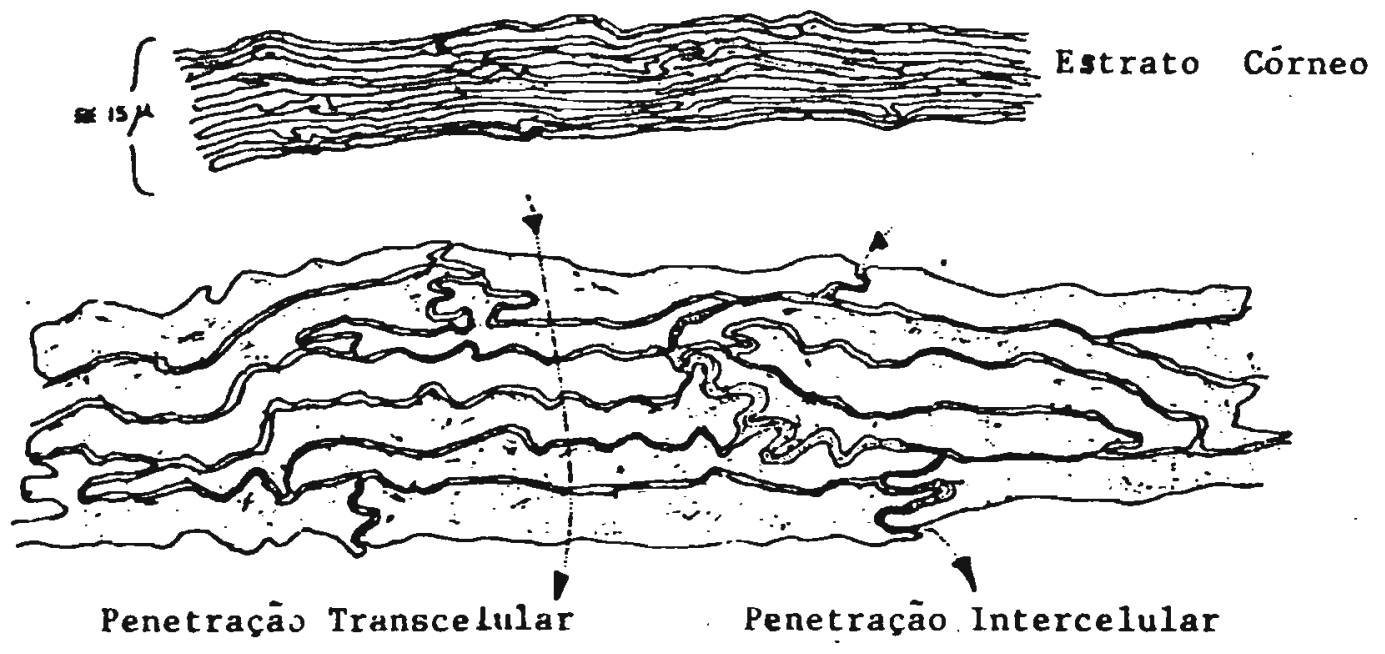

Figura 3: Representafáo da membrana do estrato cómeo, ilustrando as duas possíveis rotas de penetrafáo de substancias (105). 
Antifingicos

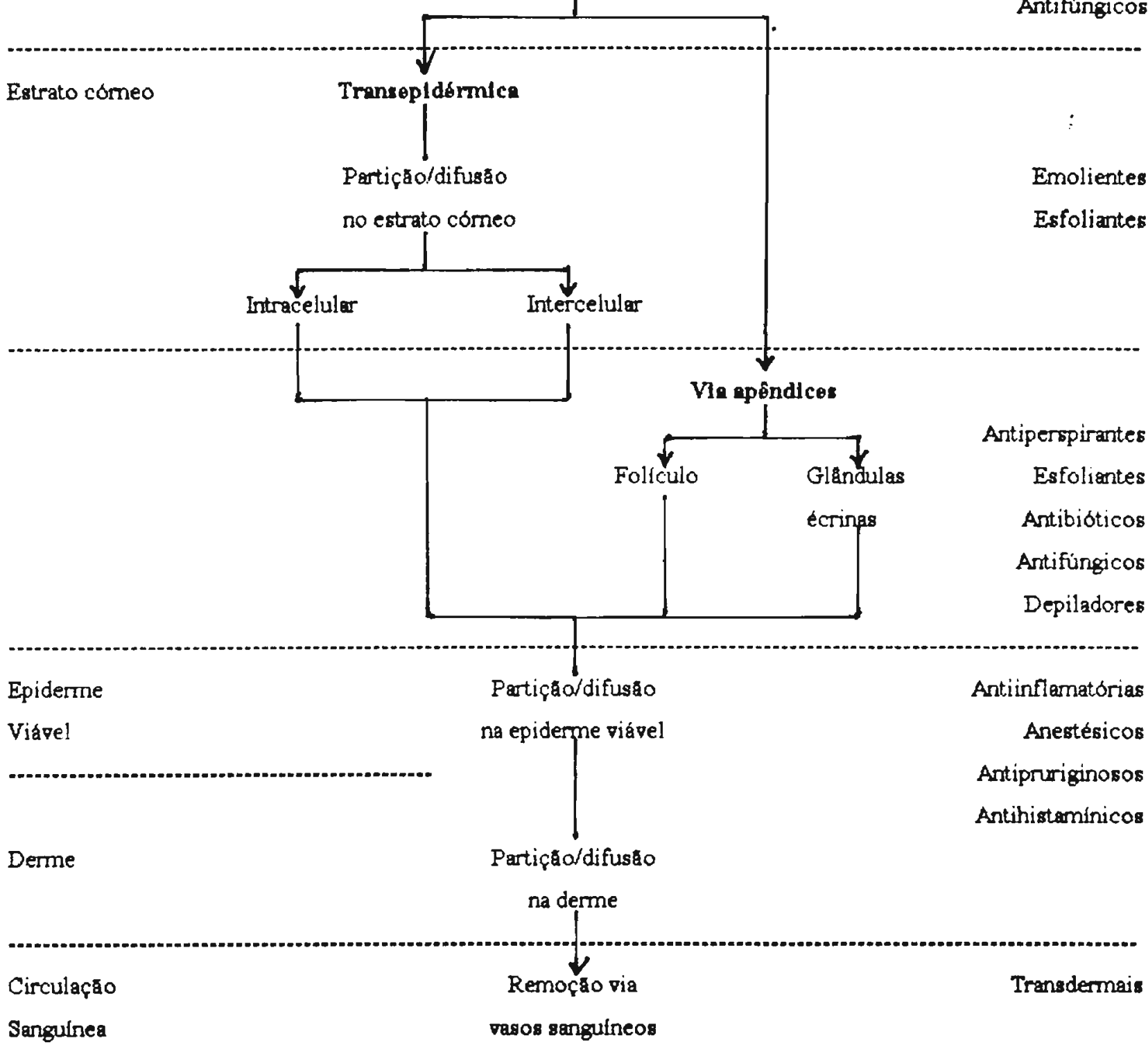

Figura 4: Rotas de penetrafão de substâncias medicamentosas na pele e exemplos de medicamentos apropriados para as patologias das varias camadas cutaneas $(6,32)$. 


\subsection{ESTUDOS IN VTTRO DE LIBERAÇAO E PENETRAÇAO CUTANEA DE FARMA- $\operatorname{COS}$}

Os métodos in vitro possibilitam entender os fenômenos que ocorrem entre a administrą̧́o do produto e o efeito medido farmacológica ou clinicamente, de maneira prática e rápida, sem a interferência de fatores biológicos. Geralmente, nos procedimentos in vitro para estudo de produtos dermatológicos, o princípio ativo difunde-se através de uma membrana artificial ou natural para uma soluçăo receptora, onde é feita a determinaçáo analítica do conteudo de princípio-ativo liberado ao longo do tempo.

\subsubsection{Terminologias}

Antes de relatarmos os trabalhos realizados por vários autores, faz-se necessário esclarecer e uniformizar várias terminologias que são encontradas em diversos artigos científicos e livros, e, que também seráo empregadas ao longo deste trabalho.

SHAH et al. (112) publicaram um interessante artigo no qual discorreram sobre os princípios e critérios para o desenvolvimento e otimizaçáo de produtos dermatológicos. Esses autores atentaram para o problema da mistura de termos que tem sido utilizados na designacáo dos processos que ocorrem nos estudos de liberafáo in vitro de medicamentos tópicos. Algumas definiçoses foram estabelecidas, como:

a) Produto dermatológico: o local de aqão é a pele. Deve apresentar uma alta retença do fárco na pele e pequeno fluxo através da mesma.

b) Produto de açào transdérmica: o efeito desejado é sistêmico. Deve apresentar baixa retençăo do fărmaco na pele e grande fluxo através da mesma. 
c) Fluxo de uma substancia na pele: quantidade de substancia que atravessa a pele em una determinada área de superficie durante um intervalo de tempo.

d) Permeaçăo e absorçăo transcutanea ou percutanea: transporte de substancia através da pele. Está relacionada com produtos transdérmicos.

e) Retenção cutânea: localização de substâncias na pele.

f) Permeável: capaz de ser atravessada ou capaz de atravessar a pele.

g) Retentiva: capaz de aprisionar substancia na pele ou capaz de ser aprisionada na pele.

b) Permeabilidade: grau com que a pele é capaz de ser atravessada por uma substância.

i) Retentividade: grau com que a pele é capaz de aprisionar uma substância

j) Permeante: substância que atravessa a pele.

\subsubsection{Aparethos utilizados nos testes in vitro}

A literatura mostra que uma grande variedade de aparelhos, nos mais diferentes modelos, tem sido empregada em estudos de cinética de liberaça e/ou permeaçáo dos fărmacos contidos em produtos de ą̧̃o transdérmica e dermatológicos $(18,30,34,37,38,42,47,48,61$, 129).

Os aparelhos dos testes in vitro podem ser denominados de "células de liberaçáo ou difusåo", cujos modelos e funcionamento såo os mais variados. De maneira geral, as células de 
difusáo funcionam por dois sistemas: a) fluxo contímuo, onde a soluça receptora é bombeada continuamente, ou b) estático, onde o volume da soluça receptora é o mesmo durante todo o experimento. TOJO (124) esquematizou de maneira aprimorável os sistemas e modelos mais comuns de difusá, conforme mostram as figuras 5 e 6.

Na figura 6, o modelo A representa un sistema de difusáo horizontal, podendo ser fabricado para pequenos $(3,4 \mathrm{~mL})$ ou grandes volumes $(140-290 \mathrm{~mL})$, sendo que, a área de difusåo (área da membrana disponivel para a difusåo) é proporcional a estes volumes. O modelo $\mathrm{B}$ mostra uma típica célula de difusăo vertical projetada por FRANZ (34), e, que tem sido utilizada frequentemente em estudo de cinética de liberą̧o e absorçáo percutânea Já o modelo $C$, representa uma típica célula de difusão de FRANZ modificada, a qual foi elaborada para solucionar os problemas que a anterior apresentava quanto a homogeneidade de mistura no compartimento receptor. $\mathrm{O}$ modelo $\mathrm{D}$ esquematiza uma célula de difusão vertical com disco rotativo acoplado a um copo de dissoluçáo da Farmacopéia Norte-Americana de um litro (89).

GUMMER et al. (42) atentaram para o problema da diferença no desempenho das diversas células de difusão utilizadas nos estudo in vittro de liberação e permeação cutânea Estes autores realizaram um estudo comparativo com diversas células de difusáo quanto a uniformidade de agitação no compartimento receptor, bem como, o volume da fase receptora Baseado nos resultados obtidos, foram selecionadas duas células de difusão de fluxo contínuo, as quais apresentaram as seguintes especificą̧రes: pequeno volume, agitą̧áo instantânea, possibilidade de variafá da ǵrea de superficie da membrana, e, também, compatibilidade com os aparelhos de agitaçáo comumente utilizados em laboratório.

BRONAUGH et al. (13) verificaram a absorçâo percutanea da N-nitrosodietanolamina (impureza presente em produtos cosméticos) empregando uma célula de difusão semelhante a de FRANZ. Os autores utilizaram trés veículos diferentes e pele humana dissecada neste estudo. 

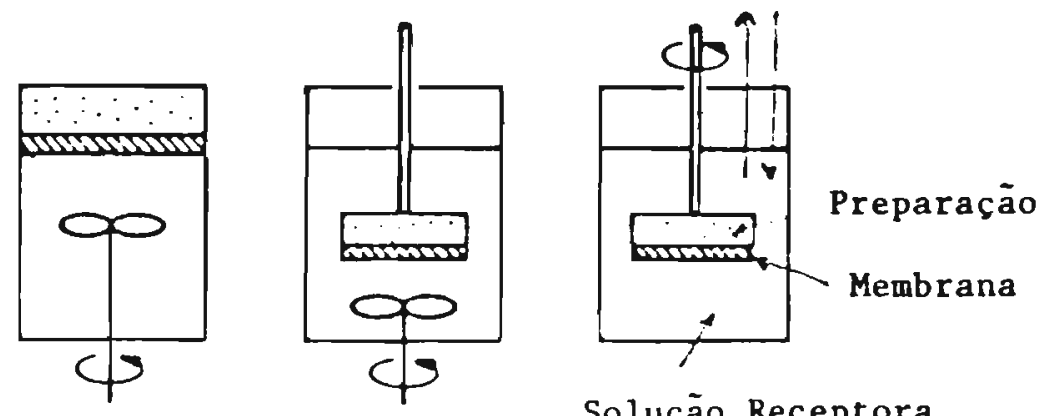

Solução Receptora

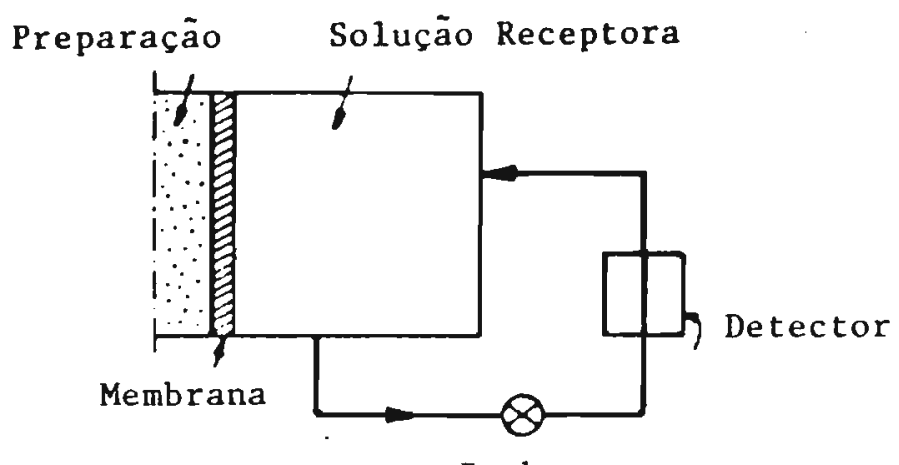

Bomba

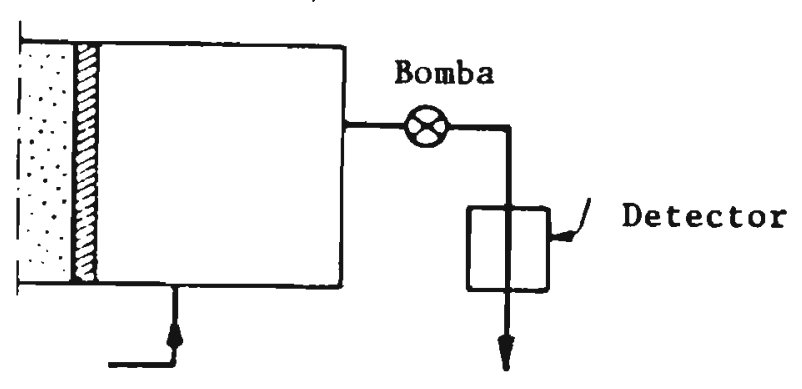

Sistema de fluxo contínuo

Sistemas estático

Figura 5: Sistemas de funcionamento de células de difusåo in vitro (124).

O aparelho projetado por OLSZEWSKI e KUBIS (83) para estudo da liberaço de princípios ativos contidos em bases de pomadas, permitiu o acompanhamento do processo de liberąåo continuadamente, pois este era provido de um sistema de coleta de fraçáo. Os testes realizados com pomadas contendo sulfatiazol mostraram-se adequados, apresentando resultados com boa reprodutibilidade. 

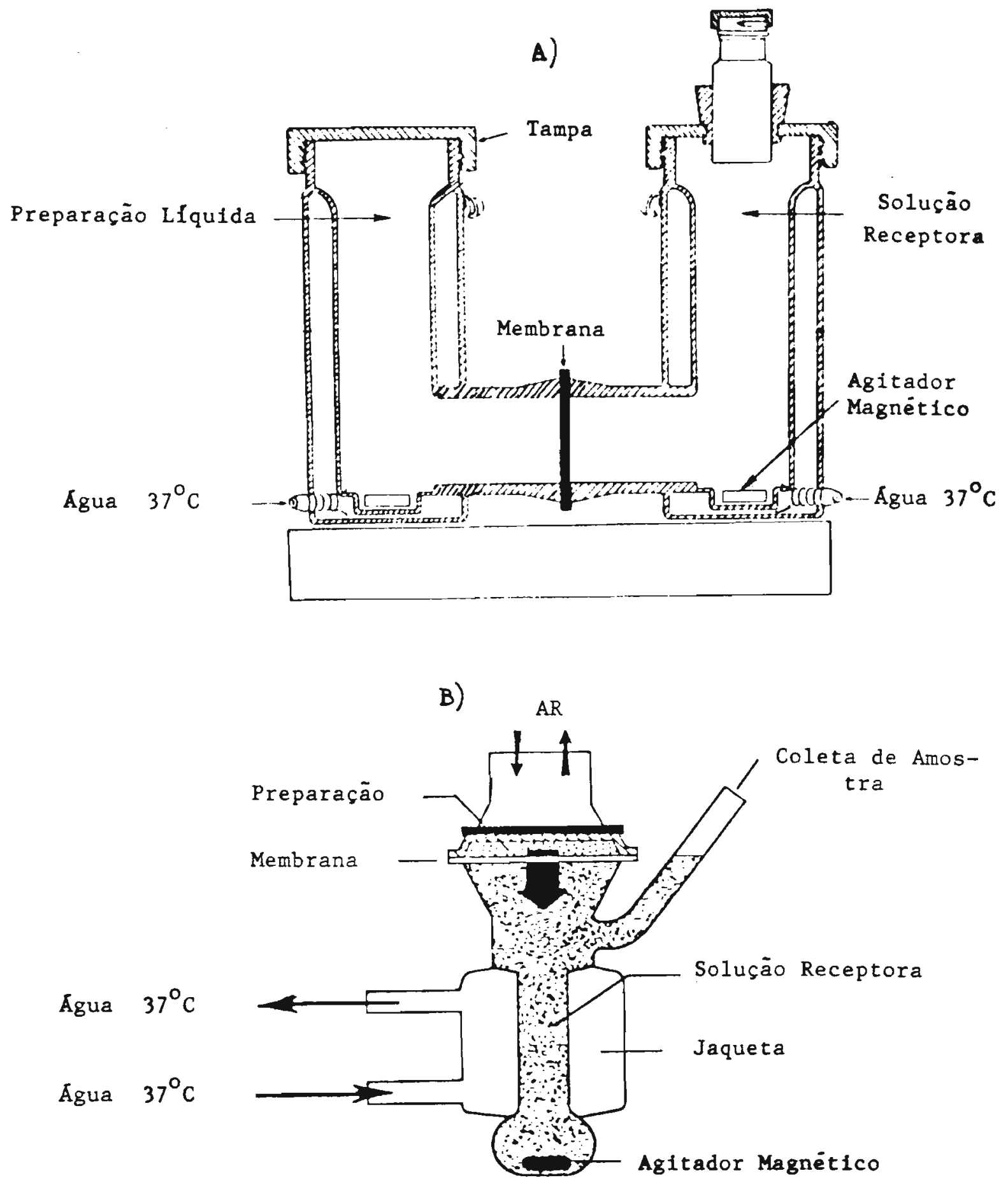

Figura 6: Modelos de células de difusão para estudos de liberação e/ou permeaçáo de fármacos contidos em produtos dermatológicos (124). 
o)

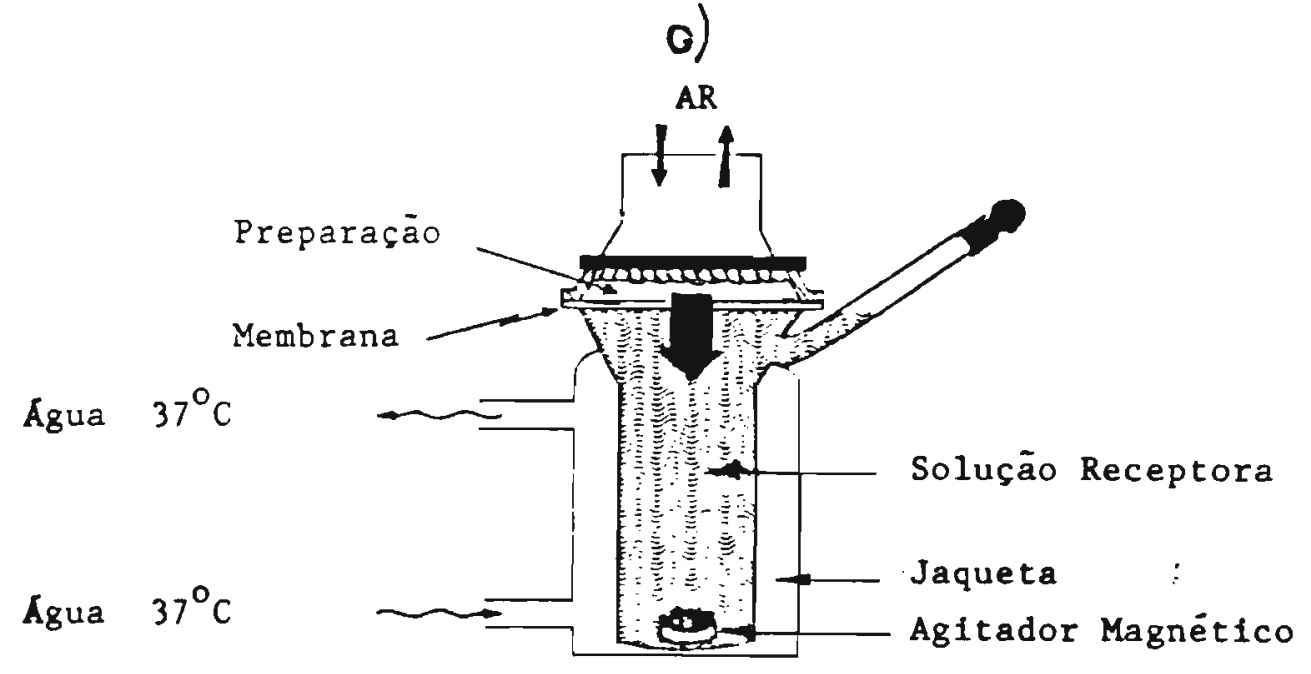

D)

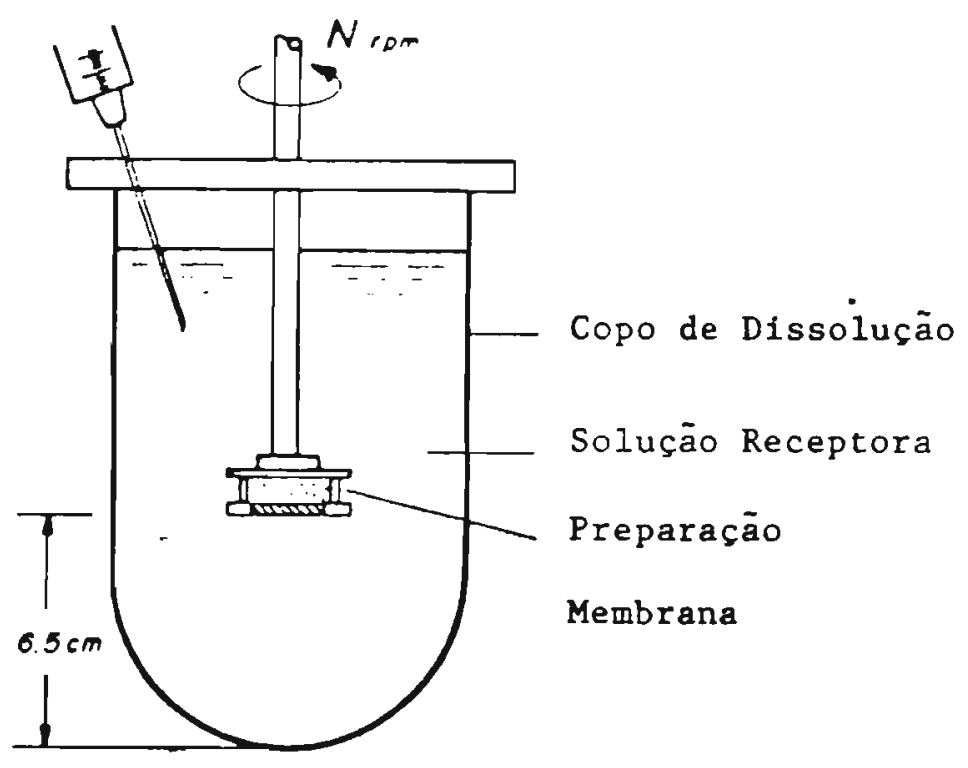

Figura 6: Contimaqáo. 
KNECZKE et al. (59) utilizaram una célula de difusáo estática para o estudo da liberąão do ácido salićlico em vaselina sólida Através deste estudo foi possível obter informaçర̃es sobre a influência da concentraçăo de ácido salićlico, bem como da viscosidade e da cristalinidade daquele veículo, na liberafáo do fărmaco em queståo.

Uma interessante célula de difusåo automatizada foi projetada por ROLLAND et al. (96) para estudar a influência da formulaçáo, soluçåo receptora, e oclusão na liberação in vitro de fármacos contidos em formas farmacêuticas de usa tópico. O sistema era provido de bomba peristáltica, através da qual a soluçáo receptora era constantemente bombeada para um detector e retornava para o conpartimento receptor. Un sistema de fluxo diferente foi adaptado a uma célula de difusáo proposta por BRONAUGH e STEWART (16), onde a soluçáo receptora entrava em contato com a membrana de difusåo através de perfusão, e as diversas amostras eram obtidas por meio de coletor de fractón.

SCHEUPLEIN et al. (105) estudou os mecanismos de absorção percutânea por meio de uma pequena célula de difusá, a qual era composta por tuas metades unidas por meio de uma presilha. Essas duas metades ficavam separadas por um disco perfurado que suportava uma membrana epidermal. Por meio deste aparelho, os autores verificaram a permeabilidade do estrato córneo a álcoois de diferentes pesos moleculares.

Um simples equipamento para estudo de liberacáo em sistema estático foi projetado por TURAKKA et al. (129). Tal aparelho consistia de um béquer onde era colocado a soluçăo receptora. Uma membrana de diálise foi presa em uma das extremidades de um cilindro de vidro e inserido no béquer para que a membrana ficasse em contato com a fase receptora. $O$ sistema todo era mantido $37^{\circ} \mathrm{C}$ e as amostras coletadas periodicamente para posterior análise da quantidade de fármaco liberada.

A avalią̧áo da cinética de absorçáo cutânea in vittro, considerando a viabilidade e 0 metabolismo da pele, pôde ser efetuada através de interessante e complexo aparelho construído por HOLLAND et al. (50). Neste equipamento as condiçðes bioquímicas de uma membrana natural (pele dissecada de camundongo) foram mantidas por meio de fluxo de meio de cultura estéril, o qual era gaseificado com $95 \%$ de oxigénio e $5 \%$ de dióxido de carbono. Nestas condiç̃es os 
autores verificaram a permeaçå cutânea do benzopireno, bem como, o metabolismo cutâneo deste composto.

\subsubsection{Membranas utilizadas nos estudos de liberaça in vitro de principios ativos cont- dos en produtos dermatologicos}

Alguns experimentos de liberafâo in vitro såo conduzidos aa ausência de membrana e constituem, basicamente, na verificaçáo da cinética de liberaça de um färmaco presente em uma formulação para uma fase imiscivel, a qual se supøe possuir propriedades semelhantes à pele. As limitą̧бes desses métodos recaem no fato de que nåo sáo consideradas as complexidades anatómicas, biologicas e fisico-quimicas da pele humana BUSSE et al. (18) estudaram a liberaçáo do 17-valerato de betametasona contido em pomadas, utilizando um sistema com uma fase oleosa líquida (a pomada) contendo o corticosteróide, flutuando sobre uma soluçáo hidroalcólica. representando a pele. Abaixo dessa solucão estava uma fase clorofórmica que simulava a circulação sanguinea. As três camadas eram agitadas e a quantidade de corticosteróide liberada dosada na fase cloroformica

Os estudos de liberação in vitro aproximam-se mais das condiç̋es in vivo quando se utilizam sistemas com membranas. Devido as amostras de pele humana serem de dificil obtenção e variarem quanto a sua permeabilidade, muitos pesquisadores usam outros materiais para simulá-la A membrana de acetato de celulose tem sido utilizada como uma membrana com caracteristicas hidrófilos em células de difusăo para estudos de liberafăo in vitro. TURAKKA et al. (129) erificaram a influência de diversos tensoativos na liberaçáo dos ácido orto-, meta- e parahidroxibenzóico contidos em bases triglicérides, utilizando uma membrana de éster de celulose em uma célula de difusåo.

Um estudo comparativo da liberafăo do ácido salićlico de uma microemulsâo e de emulsţo água/óleo, foi realizado por STUPAR et al. (119). Foi observada a influência do tipo de membrana na quantidade de ácido salicílico liberada Atingiu-se uma maior liberaça quando uma 
membrana lip6fila (nitrato de celulose) foi empregada, e, uma menor liberaç⿰丿⺄⿱㇒㠯 quando se associou tal membrana com outra de celulose regenerada

SHAH et al. (113) utilizaram uma membrana composta por uma mistura de ésteres de celulose (acetato e nitrato de celulose) no estudo de liberaçá in vitro de cremes contendo 17 valerato de betametasona $O$ fluxo da liberação deste fărmaco através da membrana foi calculado, e as curvas de liberação em regressáo linear apresentaram ótimos coeficientes de correlaço.

No estudo da liberaf̧ăo da prednisona, a partir de microemulsóes b́leo/água, GASCO et al. (38) empregaram membrana hidrófila impregnada com dodecanol. Esta membrana tratada foi pressionada sobre um membrana hidrófila formando assim, um sistema com características hidrófilas e lipófilas.

Um sistema de membrana em multicamada foi projetado por NEUBERT et al. (78) para ser empregado em estudos de penetraçáo de fármacos na pele. $O$ referido sistema funciona, segundo os autores, como receptor e pode simular a penetração de substâncias na pele humana dissecada

As membranas de dimetil-polissiloxano tềm sido extensamente utilizadas em estudos de transporte de fármacos por serem hidrófobas, de fácil preparo e permeaçåo $(12,19,39,59,64$, 79, 96).

KUROSAKI et al. (64) realizaram um estudo comparativo da permeaça do ácido flufenâmico em três modelos de membranas: pele abdominal de rato, membrana de silicone e estrato cómeo isolado de pele de cobaia Foi possível verificar que os modelos de membranas hidrófobas, como as de silicone, são inadequados para avaliar o aumento da permeação percutânea de fármacos a partir de formas farmacéuticas contendo veículos que atuam no estrato cómeo.

HATANAKA et al. (49) desenvolveram um sistema de membrana artificial composto por membrana de silicone e de poli-(2-hidroxietilmetacrilato), para estudos in vitro da permeabilidade cutânea de fármacos. Foi determinada a permeabilidade da membrana para vários fărmacos, com diferentes propriedades físico-químicas e esta, comparada com a pele dissecada de ratos sem pêlo. Os resultados obtidos mostraram que a membrana desenvolvida apresentou uma propriedade barreira similar ao modelo de pele animal utilizado. 
Dentre as membranas de origem natural, a pele humana é insubstituivel nos estudos de penetrąåa e permeação cutânea Entretanto, devido às dificuldades na aquisifáo desta membranas, as peles de animais, como ratos $(14,47,70,104,109)$, cammundongos com e sem pélo $(17,30,33$, $40,52,82,94,104)$, coelhos (27) cobaias e cricetos $(64,82,120)$, porcos $(94,104)$, câes sem pelo (94), macacos $(120,132)$ tem sido empregadas como membranas naturais.

A pele humana pode ser obtida pela dissecaça de cadáveres $(13,34,100,106,110)$ cirurgias (75). Vários procedimentos sáo utilizados no tratamento das amostras de pele humana SCHUMANN (106) utilizou pele humana da regiåo abdominal, obtida 24 horas post mortem e mantida em refrigerador por um período máximo de 12 horas. Foi possível verificar, por testes in vitro, que o butilhidroxianisol, adjuvante presente em várias formulaçós tópicas, penetra nas diversas camadas da pele. Foram considerados fatores como quantidade aplicada, área da pele exposta aos produtos, bem como metabolismo do referido fármaco na pele.

FRANZ (34) obteve ótimas correlaçס̃es entre os dados de absorção percutanea, obtidos por métodos in vitra e in vivo, de 12 compostos orgânicos. Segundo o autor, a utilização de amostras de pele humana armazenadas em congelador, por um período de três meses, não alterou as características de permeabilidade desta membrana natural.

A penetrąão de substâncias em pele dissecada pode ser verificada utilizando somente a camada epidérmica BRONAUGH et al. (13) aqueceram amostras de pele abdominal humana, em água a $60^{\circ} \mathrm{C}$, por alguns segundos, removeram a epiderme, e a utilizaram nos estudos in vitro de penetração percutânea da $\mathrm{N}$-nitrosodietanolamina, eventualmente contida em veículos cosméticos.

O limitado número de amostras de pele humana, bem como a deterioracáo da sua funça barreira durante a armazenagem săo fatores limitantes, durante a execução de numerosos experimentos. REGNIER et al. (93) propuseram a obtençao de uma epiderme reconstituída a partir de queratinócitos humanos. A medida da absorção percutânea do ácido benzóico, da testosterona e da hidrocortisona revelaram que, sob as mesmas condiçes experimentais, a epiderme reconstituída exibiu uma funça barreira com propriedades qualitativas similares a da pele humana normal, ou seja, as substancias hidrofilas penetraram mais rapidamente do que as hidrófobas. 
No sentido de verificar a validade dos resultados in vitro de absorçáo percutânea, através da pele humana e em vários modelos animais, PRfBORSKY e MOHLBACHOVÁ (91) realizaram um estudo comparativo com pele de rato, cobaia, coelho, porco, desmamado, camundongo e pele humana. A absorf̧áo percutânea de soluçóes de erioglaucina (Azul Brilhante) foi verificada em todas essa amostras de pele, sendo, o modelo animal que mais se aproximou à pele humana foi a cobaia.

WESTER e MAIBACH (131) encontraram boa correlą̧áo nos dados de absorçăo percutânea do ácido benzbico, da testosterona e da hidrocortisona em experimentos in vivo com macaco Rhesus e com humanos.

A pele de camundongo sem pêlo foi empregada em alguns estudos e apresentou-se adequada para substituir a pele humana (30). No entanto, a utilizaç⿰丿乛⿱㇒⿵冂卄丷 de pele de camundongo sem pêlo em estudos in vitto de absorf̧áo cutânea, deve ser feita de maneira cautelosa, uma vez que, este tecido parece ser susceptivel a algumas alterą̧ðes quando comparados com a pele de cadáver humano. O aumento da permeabilidade da camada cómea da pele desses animais pode ocorrer devido à excessiva hidrataçáo, ao tratamento com acetona e com promotores de penetracão. Quanto à hidratação, a permeabilidade é aumentada em relação a pele humana, somente após dois dias de experimento. Até este período, a pele de camundongo sem pêlo pode ser empregada assegurando-se uma boa semelhança a pele humana, conforme mostra a Figura $7(7,11)$. 


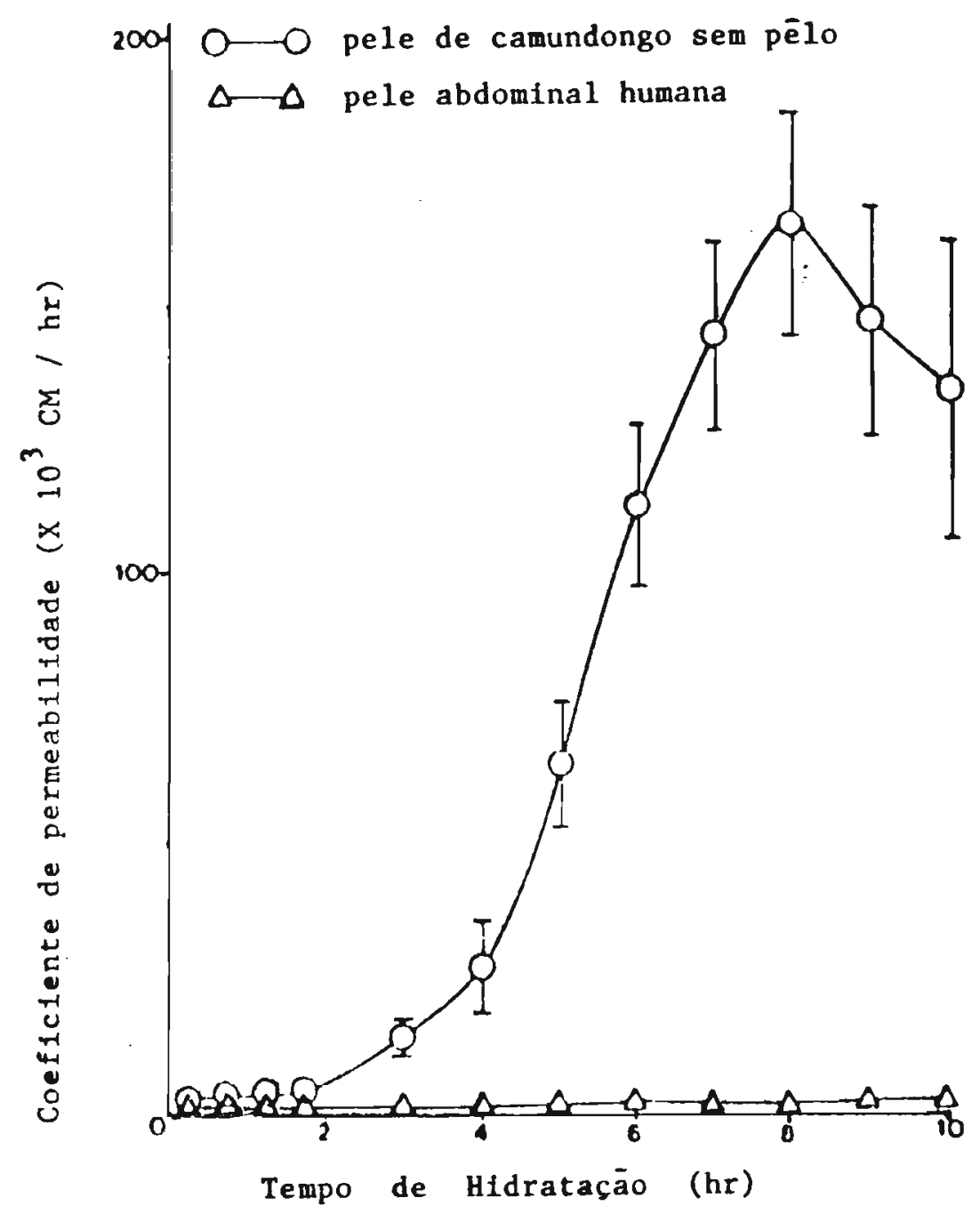

Figura 7: Coeficientes de permeabilidade para a água em funçåo do tempo de hidratação para as peles de cadáver humano e de camundongos sem pêlo (7). 
Em extenso estudo realizado por BRONAUGH et al. (15) foram determinadas as caracteristicas da pele humana e de diferentes espécies de animais, tais como espessura das camadas da pele, densidade e tamanho dos folículos pilosos, e constante de permeabilidade a diferentes compostos. Os autores concluíram através dos dados obtidos e da literatura, que a escolha do modelo animal é dependente das caracteristicas físico-quimicas da substáncia que se pretende verificar a absorção percutânea.

Muito recentemente, alguns autores estudaram o uso de pele de cobra (Elaphe obsoleta) como modelo de membrana natural para estudos de permeação. A facilidade de obtençáo desta pele e o fate de năo ser necessário sacrificar o animal săo fatores vantajosos em relą̧áo a pele de cadáveres humanos $(128,133)$.

\subsubsection{Soluçóes receptoras utilizadas nos testes in vitro}

A escolha da soluçáo receptora colocada nas células de difusăo in vitro deve ser feita criteriosamente, objetivando garantir o sucesso do experimento. Em muitos estudos, prefere-se a soluçáo isotônica tamponada a $\mathrm{pH}=7,4$ como fase receptora $(23,71,102)$. Entretanto, sempre é necessário garantir "sink conditions", ou seja, a atividade termodinâmica do fármaco no fluido receptor náo deve exceder $10 \%$ da sua solubilidade de saturą̧å para assim, ser garantida uma permeação favorável, e, assegurar uma eficiente coleta do permeante (131).

Substancias hidrófobas, as quais podem ser definidas como substancias com baixa solubilidade em água, solúveis em solventes orgánicos e altos valores de coeficiente de partiçăo óleo/água, possuem uma dificuldade em se partilhar para um meio receptor aquoso. Assim, o uso de meios nåo aquosos ou tampões isotônicos contendo solubilizantes parece ser uma alternativa.

BRONAUGH e STEWART (14) verificaram a absorfâo cutânea de dois princípios aromáticos de natureza hidrófoba através de metodologia in vitro. Soluçôes receptoras lipófilas substituiram a solufắ fisiológica, objetivando tentar melhorar a absorção e aproximar com os resultados obtidos in vivo. Assim, o soro de coelho e diluições aquosas de albumina de soro 
bovino, solventes orgânicos e quatro tensoativos nâo iónicos, foram empregados como soluçấ receptora. A soluça aquosa do polietilenoglicol-20-oleil-éter a $6 \%$, foi a que apresentou melhores resultados, uma vez que os seguintes fatores foram associados: boa correlafá com o teste in vivo, e, pequena danificaçá na membrana (pele dissecada de rato) usada no teste in vitro.

A solubilidade do fărmaco na solufão receptora e o fato desta nåo alterar a forma farmacêutica por difusáo através da membrana, foram os fatores que ROLLAND et al. (96) levaram em consideraça na escolha da soluçá receptora em seus experimentos. Foram empregadas uma substancia lipófila (derivado do ácido naftoico), uma membrana de silicone, duas fases receptoras (n-octanol e soluçáo aquosa de Polisorbato 80 a 0,25\%), bem como quatro bases tópicas. A soluq̧áo aquosa de tensoativo apresentou-se mais adequada, uma vez que o n-octanol ałravessou a membrana e dissolveu algumas das formas farmacêuticas utilizadas.

SURBER et al. (120) verificaram que a adiçá de 3,0\% de polietilenoglicol 20 ou 3,0\% de albumina, na fase receptora, aumentou o fluxo da acitretina através da pele de macaco nos experimentos in vitro.

No sentido de aproximar os resultados in vitro com as situaģ⿸es In vlvo, SCOTT e RAMSEY (108) testaram diferentes soluçoes receptoras para avaliar in vitro, a absorfáo percutanea de um inseticida piretróide através da pele de rato. As soluçбes aquosas de etanol a $50,0 \%$, de polietilenoglicol-20 cetiléter (Cetomacrogol 1000) a $6,0 \%$ e de soro de carneiro, apresentaram-se adequadas para o estudo.

\subsubsection{Estudos in vitro de theraçăo e absorçăo cutanea de corticosteroldes}

A literatura referente aos estudos in vitro de liberaçio e absorç̧o cutânea de corticosterbide é extremamente extensa Os trabalhos mais significativos estto relatados a seguir.

TANAKA et al. (121) utilizaram o acetato de dexametasona como um modelo de fármaco para investigar a influência da solubilidade e da distribuif̧́fo de uma substancia em emulsóes óleo/água nas características de liberaçăo da preparąáo. A quantidade de acetato de 
dexametasona liberada de emulsరes contendo $3,0 \%$ de Polisorbato 80 foi aumentada mas, quando a concentraçáo do fármaco era superior a $500,0 \mathrm{mg} / \mathrm{mL}$, cristais do mesmo foram observados, a a liberaça não foi mais influenciada pelo aumento da concentrafáo do tensoativo.

Os corticosteróides fluocinonida e flucloronida foram avaliados quanto à sua liberação In vitro a partir de pomadas hidrofobas contendo diferentes tensoativos (23). Os resultados obtidos mostraram que o tipo de tensoativo influencia na liberaçăo, pois as interaçøes fisico-químicas entre fármaco e tensoativo ocorrem de maneira diferente para cada substancia tensoativa.

AMERONGEN et al. (2) verificaram a liberacăo do corticosteróide budesonida em duas preparaf̧́es comerciais utilizando uma célula de difusto de fluxo continuo e membrana sintética Para validaçáo do processo de difusão foram otimizadas a soluçáo receptora, a velocidade do fluxo, a quantidade de produto aplicado etc. A budesonida apresentou uma lenta liberą̧ão quando estava incorporada em uma pomada gordurosa e rápida liberaçăo em cremes água/óleo.

NIEMI et al. (81) determinaram in vitro a liberą̧áa da hidrocortisona a partir de cremes óleo/água contendo lauril sulfato de sódio, cetomacrogol 1000 ou cetrimida $O$ lauril sulfato de sódio apresentou uma influesncia positiva na liberaçáo do fármaco. Este fato foi relacionado, pelos autores, à sua maior capacidade de solubilizaçăo do corticosteróide.

Em recente trabalho, NEUBERT et al. (79) verificaram a liberafáo in vitro de formulaçøes tópicas comerciais contendo 17-valerato de betametasona e hidrocortisona Os resultados obtidos mostraram que para uma mesma substância corticosteróide o perfil de liberą̧a difere de produto para produto. Este fato pode, segundo os autores, acarretar preparaços nåo bioequivalentes.

Várias formulaçes foram testadas por SMID-KOBAR et al. (117) quanto a liberafáo in vitro do fosfato sódio de dexametasona e da dexametasona base. Os dados obtidos foram discutidos com relą̧̃o à composif̧̃o, à viscosidade do veículo, à estrutura interna do sistems, bem como às propriedades dos fărmacos. 
SHAH et al. (113) obtiveram uma bog correlaçio entre 0 ensaio in vivo de vasoconstriçâo a a liberaça ln vitro do 17-valerato de betametasona e hidrocortisona contidas em cremes comerciais. O fluxo do corticóide através de uma membrana sintética e a velocidade de liberação foram determinados para cada formulação. As diferenças de liberafão entre as amostras de um mesmo fabricante foram atribuidas às diferenças na origem das matérias-primas e na manufatura dos produtos.

A liberafăo da triamcinolona-acetonida através da epiderme humana foi verificada por KADIR et al. (58). A influência de promotores de absorçăo percutânea também foi determinada mostrando que estes influenciam no coeficiente de partiçá da triamcinolonaacetonida entre o estrato córneo e o veículo.

COLDMAN et al. (24) conduziram um estudo in vitro para examinar a penetrafáo percutanea da fluocinolona-acetonida e seus ésteres a partir de veículos contendo diferentes quantidades de isopropanol, associados com propilenoglicol ou miristato de isopropila A penetraça foi aumentada quando da evaporafáo do isopropanol, e quando a atividade termodinâmica do corticosteróide foi aumentada nos veículos não voláteis. A precipitação do fármaco em vef́culos saturados atuou de maneira negativa na penetrafáo.

Os parâmetros: fluxo do permeante, resistência da membrana, coeficiente de partição, coeficiente de difusấ, atividade termodinf̂mica, e outros, foram determinados por KUBOTA et al. (62) quando avaliaram a absorf̧áo in vitro da betametasona base e do 17-valerato de betametasona em soluçáo aquosa. O corticóide mais liṕ́filo (éster) partilhou-se, preferencialmente, nas camadas viáveis da pele (derme e epiderme viável).

SHAHI e ZATZ (115) avaliaram o efeito da formulafăo no fluxo da hidrocortisona através da pele de camundongo. Os autores concluíram que o fluxo deste fármaco, contido em géis ou soluçøes, varia inversamente com a concentraçåo de propilenoglicol e independe da concentraf̧a de 2-propanol.

PANCHAGNULA e RISCHEL (86) comprovaram através de estudos in vitro, ex vtro e in vivo que o dietilenoglicol monoetil éter aumenta a penetrą̧áo da dexametasona e da hidrocortisona na pele, e, dimimi a permeafáo dessas substancias através da pele. Os parâmetros 
solubilidade e coeficiente de partiça 6leo/água, quantidade de fármaco retido na pele, e, distribuiçáo dos fărmacos nas camadas da pele, foram determinados e considerados quando da interpretaçăo dos resultados.

A absorçáo transcutânea, em pele de rato, da triancinolona-acetonida e outros fámacos, derivados da pirrolidona, foi verificada por SASAKI et al. (102). Segundo esses autores, a retençáo cutânea e o incremento na permeaçáo desses fămacos foi decorrente da presença dos derivados de pirrolidona.

A cinética de permeaçáo percuthea da triamcinolona-acetonida foi verificada la vitro por CHOW et al. (22) utilizando membrana sintética e pele de camundongo sem pêlo. Os autores verificaram que a penetraçáo através da membrana sintética foi diferente da membrana natural. $O$ efeito promotor da penetração percutånea do 1-dodecilazocicloheptano-2-ona foi dependente da sua concentração, e, avaliado segundo os seguintes paråmetros: fluxo do corticosteróide através das membranas, efeito reservatório na pele de animal, coeficiente de partiçáo do fármaco entre a membrana e o veículo, bem como constante de difusåo do permeante na membrana.

MIREJOVSKY e TAKRURI (73) realizaram interessante estudo do comportamento in vitro e in vivo de promotores de absorção na penetraçáo cutânea e percutânea da hidrocortisona em pele viva e dissecada de carmundongos sem pêlo. A hexametilenolauramida apresentou-Be como adequado promotor de absorçác cutânea para a hidrocortisona, mesmo em baixas concentraçoes.

A penetrą̧áo de dois corticosteróides tópicos, fluocinolona-acetonida e fluocinonida, através da pele humana foi investigada para várias formulą̧oes de géis hidrófilos contendo propilenoglicol em diferentes concentrafóes (85). A liberafø̆, a penetracto, e os resultados in vitro $e$ in vivo indicaram que o comportamento in vivo é diretamente dependente da penetrabilidade do färmaco em estudo.

O acetato de hidrocortisona e 0 17-valerato de betametasona foram empregados como modelos de fărmacos no estudo de penetraf̧áo e retenção cutânea realizado por MICHNLAK et al. (71). Os autores utilizaram pele de camundongos sem pêlo em células de difisto, para avaliar o efeito de ésteres a amidas do ácido clofibrico como promotores de absorçăo. As amidas proporcionaram uma melhor retençå̃o cuthea e penetraça transcutanea para o farmaco que os 
demais derivados. Os autores, diante dos resultados obtidos sugeriram as amidas do ácido clofibrico como adjurantes eficazes e inócuos. 


\subsection{SUBSTÂNCLAS QUE PROMOVEM A ABSORÇÃO CUTÂNEA}

Durante vários anos, pesquisadores tem sugerido diversas gubstâncias adjurantes, as quais, temporariamente, podem alterar a permeabilidade da pele. Tais substancias, se iń́cuas, poderiam ser usadas em dermatologia para aumentar a penetraçáo de färmacos, e, ainda, para tratar pacientes sistemicamente pela via cutanea A seguir tem-se o conjunto de propriedades as quais uma substância deve possuir para ser utilizada como "promotora de absorf̧åo cutânea" (6):

a) Ser farmacologicamente inerte e nน์ possuir açăo nos sítios receptores da pele ou do corpo de maneira geral;

b) Nåo ser tóxica, irritante ou alergênica;

c) Sua aça deve ser imediata à aplicafăo e a duraço do efeito deve ser adequado;

d) Quando removida da pele, o tecido deve recuperar imediata e completamente suas propriedades normais de barreira;

e) Ser química e fisicamente compatível com uma grande variedade de fármacos e veículos farmacêuticos;

D Ser um excelente solvente para os färmacos;

g) Possuir boa espalhabilidade;

h) Incorporar-se em loçøes, suspensరes, pomadas, cremes, géis, aerosóis e adesivos cutâneos;

1) Possuir baixo custo, n̊̆o possuir odor e cor e ger cosmeticamente aceitável. 
Infelizmente, nfo existe um único adjuvante que satisfaca completamente todas estas exigências. Entretanto, algumas substancias possuem muitos desses atributos, e foram investigadas clinicamente ou em laboratório, conforme relatado a seguir.

HORI et al. (51) classificaram os promotores de absorção cutânea em diagrama segundo suas propriedades fisico-químicas. Duas áreas foram delimitadas no diagrama Uma delas representou os compostos com maiores características hidrófilas, incluindo substancias como o propilenoglicol, o etanol, os derivados da pirrolidona e o dimetilsulfoxido. Na outra área, fizeram parte os compostos hidrófobos como o ácido oleico, o álcool e o ácido lauricos, o miristato do isopropila, o 1-dodecilazacicloheptano-2-ons, o n-decil metil sulfoxido e o n,n-dimetil-mtoluamida

As diferenças de hidrofilia e lipofilia das vária substâncias promotoras de absorf̧̃o cutânea fazem com que as mesmas atuem por mecanismos diferentes. A figura 8 ilustra a via polar e apolar pelas quais esses adjuvantes podem exercer seus efeitos na pela (7).

Um extenso estudo foi realizado por BARRY e BENNETT (8) com promotores de absorçáo cutânea Os modelos de fármaco polar (manitol) e apolar (hidrocortisona e progesterona) foram empregados para avaliar in vitro o modo de açăo de vários promotores de absorção: a) solventes que promovem a penetração de fármacos polares e apolares, tais como os derivados da pirrolidona, a n-metilformanida e o propilenoglicol associado a Azona; b) promotores que afetam a rota polar de penetraça, tais como o propilenoglicol associado ao decil-metil-sulfoxido; e c) acelerantes, os quais preferencialmente modificam a rota apolar, como o propilenoglicol isolado e associado ao ácido oleico.

O fato do a-bisabolol năo possuir açăo irritante ou tóxica na pele viva levaram KADIR e BARRY (57) a avaliarem, por meio de metodologia in vitro, sua atividade como promotor de penetração cutânea para produtos dermatológicos e de afăo transdérmica. Os autores verificaram que amostras de pele humana pré-tratadas com misturas de a-bisabololpropilenoglicol 1:1 apresentaram-se 17 vezes mais permeáveis ao 5 -fluoruracil e 63 vezes mais permeáveis a triamcinolona-acetonida, quando comparadas com a pele nåo tratada Os estudos de 
calorimetria realizados sugeriram que o a-bisabolol atua amentando a fluidez dos lipideos da

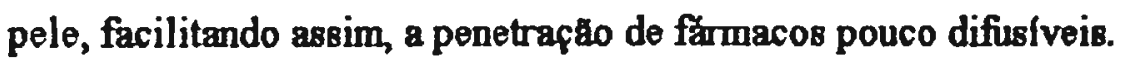

O dimetilsulfoxido representa a substancia mais estudada nos altimos anos como promotor de absorçăo cutanea $(6,26,33,54)$. 0 mecanismo pelo qual o dimetilsulfóxido altera a permeabilidade cutânea ainda nđ̃o está completamente elucidado. $\mathrm{Em}$ baixas concentrafðes, esta substância parece formar pontes de hidrogênio com a águs, proteínas, carboidratos, ácidos nucleicos, substâncias iônicas etc. Tal fato facilitaria a migrafăo de fármacos através da pele. Um outro modo possivel de afấ para o dimetilsulfóxido seria a capacidado deste em danificar ou produzir grandes mudanças estruturais na pele, quando em altas concentrafoes. A alta atividade osmótica do dimetilsulfóxido pode distorcer a estrutura laminada do estrato córneo, inchá-lo, e induzir a formaça de canais. Estes, por sua vez, promoveriam a passagem de vários fármacos. Apesar da confirmada capacidade em facilitar a penetrafẵo cutânea de fármacos, o uso do dimetilsulfoxido deve ser feito de maneira cautelosa devido ao inconveniente da irritafáo cutânea causada por este produto (123).

Os derivados de pirrolidona tem sido empregados juntamente com vários fármacos para promover a penetrą̧̃o e estabelecer um reservatório para estes no estrato cómeo $(1,103)$. SASAKI et al. (102) investigaram o efeito acelerante de penetraqăo cutanea de uma combinacão de duas pirrolidonas (1-metil-2 e 1-lauril-2-pirrolidona). A penetrafta do 5 -fluoruracil foi exacerbada na presenf̧a da combiną̧á, viabilizando, assim, a via de administrąåa transdermal para este fármaco. 

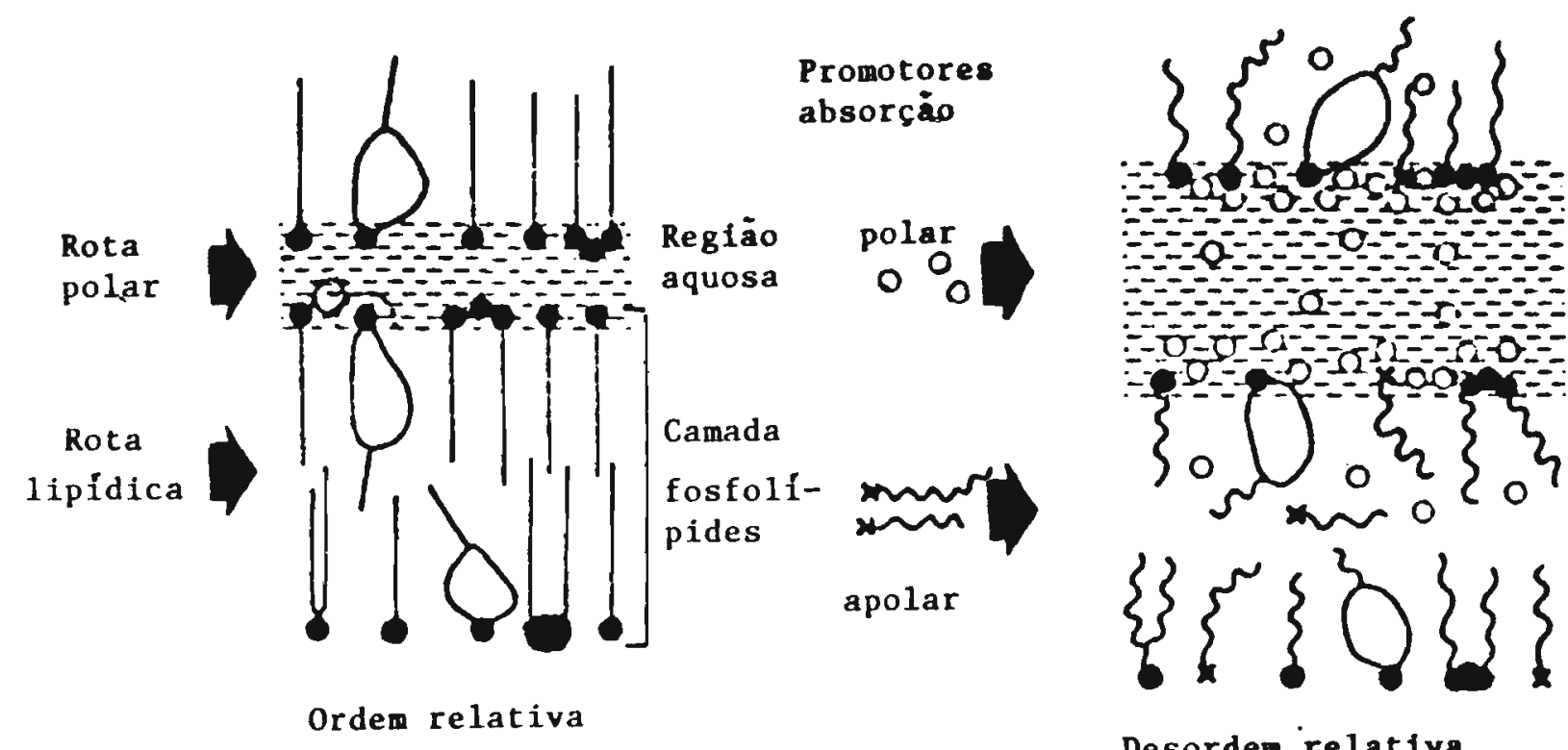

Desorden relativa

Figura 8: Mecanismo de afâo de promotores de absorção na pele (7). 
A azona (azocicloalcano-2-ona) também é um composto que tem a capacidade de alterar a permeabilidade cutânea $(6,10,41)$. Sua aplicafăo é sugerida em preparaḉes tópicas contendo anti-bacterianos, antifungicos, corticoster6ides, iododeoxiuridina e 5-fluorouracil.

O propilenoglicol e o etanol sfio solventes muito empregados como promotores de

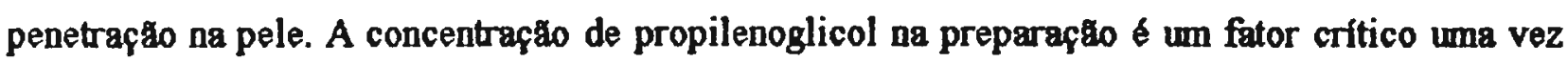
que o excesso desta substância pode aumentar o coeficiente de partição veículo/pele, comprometendo, assim, a liberaf̧ăo do fărmaco $(8,10,26,85)$. Em muitos casos, esses líquidos fincionam como co-solventes para produzir solufóes sahuradas ou quase saturadas do princípio-ativo, e, dessa forma maximizar a atividade termodinamica do penetrante. Essa otimizaça leva a um aumento da absorfáo percutanea, ainda que o estrato córneo esteja inalterado (6).

Os tensoativos representam uma classe de substância que alteram progressivamente a natureza da barreira cutânea, facilitando, assim, a penetrafăo de fármacos. Os cremes contem tensoativos como agentes emulsificantes, porém, nas concentrafães utilizadas, essas substâncias provavelmente possuem um pequeno efeito na permeabilidade cutânea Entretanto, eles podem alterar as características da pele de tal forma que promovam a passagem de substáncias hidrófilas $(6,10,29,46,101)$.

DI COLO et al. (29) verificaram a influência das interą̧ðes fărmaco-tensoativo e pele-tensoativo na absorçáo percutanea de dois färmacos (benzocaina e 2-etilhexil pdimetilaminobenzoato), os quais diferem em suas propriedades lipófilas. Os resultados obtidos sugeriram que os tensoativos empregados (monooleato de sorbitano e n-lauril éter de polioxietileno) interagiram tanto com os fámacos como com a pele. O grau destas interaçóes são dependentes da polaridade dos tensoativos e dos fărmacos.

Recentemente, KONTURRI ot al. (60) realizaram um estudo da caracteriząáo eletroquímica da pele humana por meio de espectroscopia, no sentido de avaliar os efeitos do acetato de dodecil-n,n-dimetilamino e da azona neste tecido. Estes alteradores da permeabilidade cutânea parecem abrir novas rotas de penetraça e aumentar a desordem da matriz lipoidal. Em consequeśncia foram aumentadas a resistência óhmica, as propriedades capacitivas a a dimensão fractal da pele. 
O ácido oleico apresentou-se efetivo como acelerador da permeąăo da ergotamina através da pele de coelho. Preparafóes contendo $10 \%$ de ácido oleico aumentaram cerca de 50 vezes a quantidade do farmaco penetrada após 24 horas, quando comparada com formulafóescontrole (80).

Sob o ponto de vista da segurança o da eficácia, provavelmente a água seja o melhor promotor de penetraçáo. Quase todos os fármacos såo melhor penetráveis no estrato cómeo hidratado do que no tecido seco. Baseado neste fato, a princípio, qualquer substancia a qual seja inerte farmacologicamente e promover a hidrataça do estrato córneo, pode ser considerada um acelerador de penetraf̧a. Como exemplos, podemos citar o Fator de Hidrataçáo Natural (FHN), os seus análogos e a uréia Alguns umectantes naturais localizam-se na pele, protegidos por um componente lipidico. Esses umectantes, comumente denominados como FHN, podem ser extraidos do estrato córneo pela água, após tratamento com solvente. A composiçáo do $\mathrm{FHN}$ é a seguinte: $40 \%$ ácidos graxos livres, $12 \%$ ácido carbox́lico-pirrolidona, $7 \%$ uréia, $5 \%$ śdio, 1,5\% cálcio, $4 \%$ potássio, $12 \%$ lactato etc (6).

A uréia tem sido empregada em cremes contendo corticosteróides no sentido de aumentar a hidrataçăo cutânea do estrato córneo $\mathrm{e}$, assim, promover a penetraçăo dos fărmacos. A uréia modifica o estado de hidrataçáo da camada córnea, porém, para ela atuar deve-se aguardar um tempo suficiente. Alguns estudos verificaram que cremes contendo $10 \%$ de uréia aumentam a penetraçáo cutanea de corticosteróides $(6,72)$. Para outros fármacos, a presença da uréia na formulą̧áo nåo influenciou a permeaçăo através de pele (80).

A lecitina constitui um emulsificante natural, e, devido a sua semelhança com os fosfolipídeos das membranas naturais, são atualmente adjuvantes biocompatíveis empregados em produtos dermatologicos. CHOWHAW e PRITCHARD (23) estudaram a liberafá de corticosteróides contido em pomada hidrófoba na presença de vários tensoativos e álcoois graxos, além da lecitina Os resultados obtidos mostraram que este fosfolipídeo, quando na concentracfo de $5 \%$, aumentou consideravelmente a velocidade de liberaç̆ dos corticóides. 


\subsection{HIDROGEIS E SUA UTILZAÇĀO RM SISTEMAS DE LIBERAÇĀO DL FARMACOS}

Os hidrogeis heterogêneos sţo formados a partir de mistura de polímeros, de copolímeros segmentados ou de polímeros interpenetrantes. Estes veiculos tem sido muito investigado como carreadores de farmacos, devido as seguintes caracteristicas: a) grande compatibilidade com os tecidos devido a mínima irritą̧a mectnica resultante do seu alto conteúdo aquoso; e b) propriedades de transporte de massa dos hidrogéis manipulados por nivel ou cinética de intumescimento $(24,87,126)$. A combinafto de polímeros hidrofilos e hidrofobos produz hidrogéis compostos com fases separadas. O processo de combinaçáo é um método simples, o qual associa as vantagens dos diferentes materiais, assim, o polímero resultante, algumas vezes, apresenta propriedades sinérgicas. As vantagens do sistema de combiną̧ão de polímeros no controle de liberaça de fármacos estão relacionados com a facilidade na fabricaçåo das preparaf̧̋es, a manipulą̧⿸厃 das propriedades das preparaçes (hidrafafáo, velocidade de degradaçáo e força mecânica), a carga de fármaco e a utilizaça da fase dispersa predominante como um microreservatório para aumentar as propriedades de liberafáo. Alguns sistemas de hidrogeis sáo sintetizados usando segmentos de polimeros hidrofilo/hidrófobo, blocos ou enxertos de co-polímeros e polímeros conjugados por ligą̧бes químicas covalentes. Os co-polímeros anfifilicos formados por dois ou três blocos podem ser sintetizados com polioxietileno biodegradável ou næo (5).

O interesse na aplicaçáo de um bloco especifico de co-polimero (polioxietileno/polioxipropileno/polioxietileno) na liberafăo de farmacos está baseada em sua transiçăo gel-sol termo-reversivel. Este bloco de co-polímero contém aproximadamente 70,0\% de polioxietileno e um peso molecular de 12.500 . No comércio pode-se encontrar este produto sob duas denominaçres Pluronice PF-127 ou Poloxamer 407. Devido as caracterfsticas de sua estrutura molecular, este bloco de co-polímero forma micelas em soluça aquosa e exibe gelatinizaç⿰丿⺄⿱丷三 termo-reversa em concentrafóes acima de $20,0 \%$, isto é, apresenta-se como um líquido à baixas temperaturas e um gel quando atinge a temperahura ambiente (126). 
ATTWOOD e colaboradores (3) estudaram as propriedades micelares do bloco de co-polímeros polioxietileno / polioxipropileno em água e em soluçőes de eletrólitos por espectroscopia de fóton, dispersø⿸ de luz e viscosimetria Os autores verificaram, por esses métodos, que o aumento da temperatura resulta em uma desidrataça micelar. Esta desidratafão micelar é causada por mudanças conformacionais nas cadeias de polioxipropileno, levando a expulsão da água além de um aumento no volume anidro da micela $\mathrm{O}$ aumento do tamanho micelar foi um outro fator observado nos experimentos.

TOMIDA et al. (126) verificaram as caracterfsticas de liberafáo in vitro do diclofenaco e da hidrocortisona incorporados de géis de Poloxamer 407. O aumento da concentrafáo do co-polímero no gel diminuiu a liberaça do corticbide. No caso do diclofenaco, 0 $\mathrm{pH}$ do gel foi crítico no controle de sua velocidade de liberaçăo, sugerindo a ocoméncia de interafóes entre a forma ionizada de fármacos hidrófobos com as micelas nåo iónicas do copolímero.

Os blocos de co-polímeros a base de óxidos de etileno e propileno tem apresentado interesse como agentes solubilizantes. COLLETT e TOBIN (25) verificaram a relaf̧a que existe entre a estrutura de vários blocos de co-polímeros e solubilizafão de algumas acetanilidas parasubstituídas. Os autores concluíram que a solubilizafáa destas substâncias parecem depender tanto da estrutura do co-polímero como da natureza do soluto. 


\subsection{ANALISE DE CORTICOSTEROIIDES POR CROMATOGRAFIA LIQUIDA DE ALTA EFICIENCLA (CLAE)}

As metodologias analíticas empregadas em experimentos in vitro de liberafáo e penetraf̧ấ cutânea devem ser seletivas e de alta sensibilidade, uma vez que sấo pequenas as quantidades de fármacos a serem dosados. Os métodos mais adequados sáo o radioimmoensaio e a cromatografia líquida de alta eficiência (CLAE) (112).

A CLAE tem sido empregada em muitos estudos de liberafăa in vitro e absorçă ln vivo de corticosterbides $(63,71,86,102,113)$. Para a análise dessas substâncias em formas farmacêuticas, a metodologia por CLAE também é adequada

ORR et al. (84) empregaram a CLAE como metodologia analítica para verificar a uniformidade de dosagem em sete pomadas comerciais contendo hidrocortisona a 1\%. Após extrą̧̃o com dimetilpentano e metanol, o conteúdo de hidrocortisona foi determinado utilizandose fase móvel metanol: água (75:25) a um fluxo de 1,4 mL/min, coluna Spherisorb 5ODS (25 cm x $4,6 \mathrm{~mm}$ ), volume de injeção de $20,0 \mathrm{~mL}$ e norestisterona como padráo interno.

$O$ diacetato de diflorasona foi quantificado em cremes e pomadas através de CLAE, sob as seguintes condį̧ðes: coluna de sílica $(10 \mathrm{~cm} \times 4,6 \mathrm{~mm}$ ) de $3 \mathrm{~mm}$ de diâmetro: fase móvel cloreto de butila, saturado por água: cloreto de metileno, saturado por água: tetrahidrofurano: ácido acético (350:125:10:15), fluxo de $2,5 \mathrm{~mL} / \mathrm{min}$ e diacetato de isoflupredona como padráo interno. As amostras forma submetidas a extrą̧ão com clorofórmio e posteriormente à and́lise por CLAE a $254 \mathrm{~mm}$ A recuperafão do diacetato de diflorasona nas diferentes amostras ficaram em torno de $100 \%$. O método proposto apresentou-se reprodutivel e adequado para utilizafáo em estudos de estabilidade (116).

GAGNE e LODGE (36) analisaram o fosfato sódico de dexametasona contido em preparaçбes farmacêuticas (soluçбoes oftálmicas, inję̧ðes e inalantes) através de CLAE. As determinaçбes foràm realizadas após diluiçăo das amostras e padráo interno com a fase móvel dihidrogêniofosfato de potássio a $0,07 \mathrm{M}$ : tetrahidrofurano: metanol (300:18:182), fluxo de 1,5 
$\mathrm{mL} / \mathrm{min}$, coluna cromatográfica $\mathrm{C}_{18}(30 \mathrm{~cm} \times 3,9 \mathrm{~mm}), 5 \mu \mathrm{L}$ de injęão e deteç̧̃̃o a $254 \mathrm{~mm} .0$ padrăo interno foi o dietilftalato. O método empregado apresentou linearidade em 0,15 a $1,50 \mu \mathrm{g} \mathrm{e}$ coeficiente de correlaquăo igual a 0,9999. O fosfato de dexametasona pôde ser detectado na presença de excipientes e fármacos, os quais normalmente estăo presentes nas formulą̧бes examinadas.

TOKUNAGA et al. (125) desenvolveram um ensaio por CLAE para a determinaçáo de vários corticosteróides que normalmente estáo presentes em cremes e pomadas. As condiços cromatográficas empregadas foram coluna de fase reversa $\mathrm{C}_{18}$, fase móvel acetonitrila: água (45:55 ou 55:45). As amostras sofreram prévia extrafão em coluna de sílica eluidas com diclometano e metanol (4:1). Através deste método foi possível separar e quantificar o acetato de cortisona e de dexametasona, a fluormetolona, e o valerato de betametasona das preparafóos dermatológicas.

Um sensivel em seletivo método por CLAE em fase reversa foi desenvolvido por MARON et al. (67) para a determinąáo e verificąão da estabilidade do 17-benzoato de betametasona contido em veículos hidrófobos. A 17-metiltestosterona foi empregada como padrão interno. A extraçáo do corticbide foi realizada com metanol e acetonitrila (7:2), cromatografadas em coluna de fase reversas $C_{18}$, fase móvel metanol: acetonitrila: água (7:2:4), e detectadas no ultra-violeta a $254 \mathrm{~mm}$. O método apresentou linearidade nas concentraçðes de 25 a $62,5 \mu \mathrm{g} / \mathrm{mL}$.

A determinafto de corticosteróides em fluidos biologicos por CLAE é muito empregada em" estudos de biodisponibilidade. TOOTHAKER et al. (127) realizaram um estudo comparativo entre a CLAE com deteç̧á no ultra-violeta e fluorescência para analisar a hidrocortisona em plasma humano. O método cromatográfico empregou a 4-pregnona-17a, 21triol-3, 11-diona como padrao interno. A hidrocortisona foi extrafda das amostras de plasma, previamente basificadas, por cloreto de metileno. $O$ resíduo seco da fase organica foi ressuspenso na fase móvel (solufáo aquosa de metanol a $60 \%$ ) e $20 \mathrm{~mL}$ foram injetados no cromatografo. Os autores empregaram pre-coluna $(2,1 \times 70 \mathrm{~mm})$ e coluna de fase reversa $(4,6 \times 250 \mathrm{~mm})$, através da qual foi bombeada a fase móvel a um fluxo de $1,0 \mathrm{~mL} / \mathrm{min}$ A deteç̧áo ocorreu a $254 \mathrm{~mm}$ e os tempos de eluiçáo foram 10 e $8 \mathrm{~min}$ para hidrocortisona e o padráo interno, respectivamente. $O$ 
método acima apresentou uma linearidade entre 5,0 e $700,0 \mathrm{ng} / \mathrm{mL}$ e boa correlaça com o método de CLAE com detector de fluorescência.

A determinaça simultanea da betametasona, do acetato de betametasona e da hidrocortisona em fluidos biológicos foi realizada por PETERSEN et al. (88) através de CLAE. O acetato de hidrocortisona foi empregado com padráo interno e as amostras (plasma, sangue e urina) foram extraídas com diclorometano seguido de cromatografia em um sistema de fase reversa (columa $C_{8}$ de $250 \mathrm{~mm} \times 4,6 \mathrm{~mm}$ e $10 \mu \mathrm{m}$ de diâmetro) e, eluif̧áo com a fase móvel metanol: água (60:40). A deteçáo a dois comprimentos de onda (254 am e $240 \mathrm{~nm}$ ) foi empregada para ensaiar a especificidade do sistema e a sensibilidade encontrada foi 10 ng de cada corticosterbide. Os autores năo utilizaram a alcalinizaçáo no processo de extrafăo para evitar a hidrólise dos ésteres. A estabilizaçáo destes ésteres nas amostras de fluidos biológicos foi possivel com a utilizaçăo de sal sódico do ácido etilenodiaminotetracético a concentrą̧a de $0,1 \% \mathrm{p} / \mathrm{y}$.

ROSE e JUSKO (97) desenvolveram um sensivel, especifico e reprodutivel método de CLAE para determiną̧a simultânea da prednisona, prednisolona e cortisol em fluidos biológicos, empregando a dexametasona como padrấo interno. As amostras foram extraidas com cloreto de metileno, lavadas com soluça de hidróxido de sódio e cromatografada em uma coluna de sílica microparticulada, com deteç̧áo no ultra-violeta a $254 \mathrm{~nm}$. A fase móvel empregada foi metanol: cloreto de metileno (3:97) com fluxo de 2,0 mL/min. A sensibilidade do método foi maior do que $15 \mathrm{ng}$ para os quatro corticosteróides, apresentado-se adequado para 0 acompanhamento da biodisponibilidade da prednisona em pacientes que fazem uso deste färmaco. 
3 - PROPOSIÇÃO 
Este trabalho foi planejado com as seguintes fases de execuçăo:

1 - Preparo de formulaçóes dermatológicas a base de bloco de Poloxamer 407 contendo como adjuvante uréia ou lecitina, para incorporaço de corticosterbide;

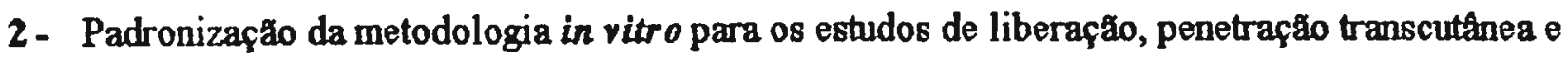
retençăo cutânea na pele de animal;

3 - Padronizaçåo da metodologia analitica para determinaçáo dos corticosteróides por CLAE nas formulaçðes, nos estudos de liberaçấo e na pele de animal;

4- Estudos in vitro de liberaçăo, penetrą̧åo transcutânea e retenção cutânea dos corticosteróides contidos nas formulą̧⿸丆es desenvolvidas. 
4 - MATERIAL E METODOS 


\subsection{MATERIAL}

\subsubsection{Solventes, reagentes e matérias-primas}

- Acetato de hidrocortisong; USP XXI

- Acetato de dexametasong; USP XXI

- Triamcinolona-acetonida; USP XXI

- Desonida; USP XXI

- Timerosal; USP XXI

- Bloco de co-polímero (POE/POP/POE) - Pluronic? PF-127, BASF Wyandotte Corp.;

- Uréia p.a; Reagen;

- Propilenoglicol p.a; Reagen;

- Vaselina líquida, FAVAb;

- Lecitina (L-a-fosfatidilcolina de soja, Catálogo Sigma n P5638, Lote 121H0048);

- Mistura de metil, etil, propil e butil-parabeno e fenoxietanol - Phenonip (8), Croda;

- Cloreto de sódio p.a, MERCK;

- Fosfato monobásico de sódio p.a, Ecibra;

- Fosfato dibásico de sódio p.a, Ecibra;

- Polietilenoglicol-20 etil éter (Cgtálogo Sigma n 5884, Lote 120H0360);

- Metanol para cromatografia Lichrosolvo, MERCK;

- Cloroformio p.a, MERCK.

- Miristato de isopropila (Catálogo Sigma no 8136, Lote 53H0375);

- EDTA sódico p.a, Reagen; 


\subsubsection{Soluçros padræo}

- Soluçåa estoque de desonida (11B, 21-Dihidroxi-16a, 17a-isopropilidenodioxypregna-1, 4-dieno-3,20-diona) na concentrafá de $1,0 \mu g / \mathrm{mL}$ - $2,0 \mu g / \mathrm{mL}$ (Padrao interno), em metanol;

- Soluçáo estoque de triamcinolona-acetonida (9a-Flúor-11B, 21-Dihidroxi-16a, 17a -isopropilidenodioxipregna-1, 4-dieno-3, 20-diona) na concentrąáo de 1,0 $\mu \mathrm{g} / \mathrm{mL}$, em metanol;

- Solução estoque de acetato de hidrocortisona (21-Acetoxy-4-pregneno-11B, 17a, 21 -tiol-3,20-diona, Catálogo Sigma n ${ }^{\circ} \mathrm{H}-4126$, Lote $62 \mathrm{H0654}$ ) na concentraçăo de 1,0 $\mu \mathrm{g} / \mathrm{ml}$, em metanol;

- Soluçáo estoque de acetato de dexametasona (9a-Flúor-16a-metil-11B, 17a, 21 -Trihidroxi-1,4-pregnadieno-3,20-diona-21-acetato, Catálogo Sigma no D-1881, Lote 107F0949), na concentrą̧ăo de $1,0 \mu \mathrm{g} / \mathrm{mL}$ e 4,0 $\mu \mathrm{g} / \mathrm{mL}$ (Padráo interno), em metanol;

- Solução estoque de dexametasona (9a-Fluor-11B, 17a, 21-Trihidroxi-16a-metilpregna-1, 4-dieno-3, 20-diona, Catálogo Sigma no D-1756, Lote 23H0091) na concentrafáo de $1,0 \mu \mathrm{g} / \mathrm{mL}$, em metanol;

- Soluçấo estoque de hidrocortisona (11B, 17a, 21-Trihidroxipregna-4-eno-3,20-diona

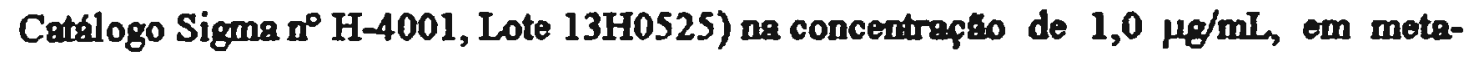
nol. 


\subsubsection{Equipamentos e acessórios}

- Cromatógrafo líquido, modelo CG 480-C, acoplado a um detector ultra-violeta, com comprimento de onda fixado a $254 \mathrm{~nm}$, volume do injetor igual a 20,0 $\mu \mathrm{L}$.

- Coluna cromatográfica LICLOCART RP-18-50957/0001 - MERCK, $125 \mathrm{~mm} \times 4 \mathrm{~mm}$, $5 \mu \mathrm{m} ;$

- Pré-coluna RP-18-50957/0001 - MERCK, 4mm x 4mm, 5 $\mu \mathrm{m}$;

- Registrador potenciométrico CG, modelo 1001;

- Membranas para filtraçáo de solventes organicos MILIPOREQ (FHUP), 0,5 um;

- Ultra-som, Microsonic, modelo SX-20;

- Agitador mecanico TAYO S-SF, tipo "Mixer";

- Agitador mecânico horizontal (220 $110 \mathrm{ciclos} / \mathrm{min})$, Pachane, modelo TE 240;

- Balança analítica "Mettler" H 10W, para carga máxima de $160 \mathrm{~g}$

- Micropipetas automáticas ajustáveis de 1 a $100 \mathrm{~mL}, 100$ a $1000 \mathrm{~mL}$ e 1 a $10 \mathrm{~mL}$.

- Microseringa de $25 \mathrm{~mL}$ - HAMNTON; 
- Papel de filtro qualitativo, $12,5 \mathrm{~cm}$ de diâmetro;

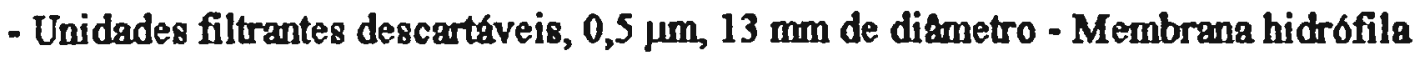
modificada PTFE, Cátálogo Sigma no Z22.742-0, Lote 93H0959);

- Pipeta de polietileno para transferéncia de líquidos - SIGMA, capacidade $2 \mathrm{~mL}$;

- Centrifuga FANEN, Modelo 201;

- Baloes volumétricos de 10,50 e $100 \mathrm{~mL}$;

- Pipetas graduadas de 1,5 e $10 \mathrm{~mL}$;

- Pipetas volumétricas de $1 \mathrm{~mL}$;

- Funil de vidro;

- Funil de separaqáo de $500 \mathrm{~mL}$;

- Béqueres de vidro de 40 e $80 \mathrm{~mL}$;

- Luvas cirúrgicas;

- Tesoura e pinça para dissecafá;

- Tubos de extrafato de 13 × $100 \mathrm{~mm}$, com tampa esmerilhada;

- Tubos conicos de $16 \mathrm{~mL}$; 
- Aparelho de dissoluçáa - SOTAX AT 7;

- Viscosímetro RHECOTEST 2.1 (VEB-MLW-DDR, Lamedid);

- Banho termostatizado - circulafáo de águs, VEB MLW-Prafgerate - WERK Medingen Sitz Freital;

- Medidor de pH - DIGMED;

- Agitador magnético;

- Células de liberaçá in vitro,

- Bomba à vácuo;

- Membranas de dílise, acetato de celulose $33 \mathrm{~mm} \times 30 \mathrm{~m} / 12-14.000$ P.M.;

- Tubos plásticos de 2 mL para coleta e armazenamento de amostras, SIGMA;

- Folhas de pepel aluminio;

- Potes plásticos com capacidade para $100 \mathrm{~g}$

Observaçбes: As vidrarias foram submetidas a lavagem com ácido cloridrico $6 \mathrm{~N}$, durante 12 horas e enxaguadas com água destilada antes do uso. 


\subsubsection{Animais de laboratorio}

Camundongos sem pêlo, machos com quatro a seis semanas de idade, linhagem HRS/J,

Laboratórios Jackson, Bar Harbor, Me, gentilmente doados pelos Laboratórios Johmson \& Johnson, Brasil.

\subsubsection{Formulaçð̃es desenvolvidas}

As formulą̧øes dermatologicas descritas a seguir foram empregadas nos experimentos do presente trabalho.

\subsubsection{Géis hidrófilos contendo uréia}

As preparaçøes contendo uréia encontram-se descritas na Tabela 1. 
Tabela 1 - Formulą̧ðes de géis hidrófilos contendo uréia

\begin{tabular}{|c|c|c|c|c|c|}
\hline \multirow[t]{2}{*}{ Componentes } & \multicolumn{5}{|c|}{$\% p / v$} \\
\hline & $\mathbf{G}_{\mathbf{l}}$ & $\mathbf{G}_{2}$ & $\mathbf{G}_{3}$ & $\mathbf{G}_{4}$ & $\mathbf{G}_{3}$ \\
\hline Poloxamer 407 & 25,0 & 25,0 & 25,0 & 25,0 & 25,0 \\
\hline Propilenoglicol & 5,0 & 5,0 & 5,0 & 5,0 & 5,0 \\
\hline Uréia & 2,0 & 4,0 & 8,0 & 12,0 & 15,0 \\
\hline $\begin{array}{l}\text { Corticosteróide } \\
\text { Mistura de metil, propil e butil-parabeno }\end{array}$ & q.s. & q.s. & q.s. & q.s. & q.s. \\
\hline e fenoxietanol & 0,75 & 0,75 & 0,75 & 0,75 & 0,75 \\
\hline EDTA sódico & 0,1 & 0,1 & 0,1 & 0.1 & 0,1 \\
\hline Água destilada - qsp & 100,0 & 100,0 & 100,0 & 100,0 & 100,0 \\
\hline
\end{tabular}

Para cada uma das cinco formulaçoes de géis hidrófilos foram adicionados os seguintes corticosteróides:

- Acetato de hidrocortisona (AHC), 1,0\% ou

- Acetato de dexametasona (ADM), $0,1 \%$ ou

- Triamcinolona-acetonida (TA), $0,1 \%$ ou

- Desonida (D), 0,05\%. 
A preparaf̧oes foram manipuladas com a seguinte técnica de preparo:

- Dissolveram-se a uréia, a mistura de conservantes, e o EDTA sódico em aproximadamente $80,0 \mathrm{~mL}$ de água destilada. Nesta soluçá dispersou-se o Poloxamer $407 \mathrm{em}$ banho de gelo sob constante agitą̧ão. Após total hidratą̧̃o e dispersão do polímero, transferiu-se o produto obtido para um baláo volumétrico de $100 \mathrm{~mL}$, o qual também foi mantido em banho de gelo. Dissolveu-se em separado a quantidade adequada de corticoster6ide em 5,0 mL de propilenoglicol e verteu-se esta soluçáo para o balăo volumétrico. Completou-se o volume com água destilada, agitou-se e transferiu-se o produto obtido, ainda a baixa temperatura $\left( \pm 4^{\circ} \mathrm{C}\right)$, para potes de $100 \mathrm{~g}$ Apbs atingir a temperatura ambiente, obtiveram-se géis viscosos, transparentes e incolores.

\subsubsection{Géis hidrofilos contendo lecitina}

As preparaçøes contendo lecitina encontram-se na Tabela 2. 
Tabela 2 - Formulaçøes de géis hidrófilos contendo lecitina

\begin{tabular}{|c|c|c|c|c|}
\hline \multirow{2}{*}{ Componentes } & \multicolumn{4}{|c|}{$\%$ ptv } \\
\hline & $: \mathbf{L}_{\mathbf{l}}$ & $\mathbf{L}_{2}$ & $\mathbf{L}_{3}$ & L.4 \\
\hline Poloxamer 407 & 18,0 & 18,0 & 18,0 & 18,0 \\
\hline Propilenoggicol & 5,0 & 5,0 & 5,0 & 5,0 \\
\hline Lecitina & 1,0 & 2,0 & 4,0 & 8,0 \\
\hline Vaselina bquida & 5,0 & 5,0 & 5,0 & 5,0 \\
\hline Corticosteróide & q.s. & q.s. & q.s. & q.s. \\
\hline $\begin{array}{l}\text { Mistura de metil, etil, propil e } \\
\text { parabeno e fenoxietanol }\end{array}$ & 0,75 & 0,75 & 0,75 & 0,75 \\
\hline EDTA sódico & 0,1 & 0,1 & 0,1 & 0,1 \\
\hline Água destilado qsp & 100,0 & 100,0 & 100,0 & 100,0 \\
\hline
\end{tabular}

Da mesma forma que nas formulaçoes de géis contendo uréia, foram adicionados os corticosteróides em concentraçס̃es adequadas nas formulą̧ð̋es acimas.

A técnica de manipulaf̧a dessas preparaçôes foi realizada da seguinte maneira:

- Dispersou-se, em banho de gelo, o co-polímero em aproximadamente 70,0 mL de água destilada, sob constante agitą̧á. Verteu-se este produto para um balăo volumétrico de $100 \mathrm{~mL}$ o qual foi mantido sob banho de gelo. Adicionou-se a mistura de conservantes e o EDTA sódico. Em separado dispersou-se a lecitina em $5,0 \mathrm{~mL}$ de vaselina líquida em un béquer, sob leve aquecimento. Transferiu-se a dispersăo obtida para o balâo volumétrico, agitou-se e adicionou-se o corticosteróide previamente dissolvido em 5,0 mL de propilenoglicol. Completou-8e o volume 
com água, agitou-se e verteu-se o produto ainda à baixa temperatura, para potes plásticos de $100 \mathrm{~g}$ Na temperatura ambiente obtiveram-se produtos viscosos, leitosos e de cor levemente amarelada 


\subsection{METODOS}

\subsubsection{Determinaçăo das propriedades fisico-químicas das formulaçōes}

\subsubsection{Determinaço do $\mathrm{pH}$}

A determinaça do $\mathrm{pH}$ dos géis obtidos foi realizada em medidores de $\mathrm{pH}$, ap6s diluição dos produtos em água na proporçǿo 1:10.

\subsubsection{Determinacão do comportamento reológico (6)}

A reologia das formulaçøes desenvolvidas foi determinada em o viscosímetro RHEOTEST 2.1.. Este equipamento é um viscosimetro de rotąão e serve para a determinaçáo das propriedades reológicas de líquidos newtonianos e nåo newtonianos. Permite avaliar os seguintes fenômenos de escoamento: viscosidade, dilatancia, plasticidade, tixotropia e reopexia

No presente trabalho, $25,0 \mathrm{~g}$ de cada uma das formulafoes foram colocadas na fenda anular de um sistema de cilindros coaxiais. O cilindro externo estacionário, forma o recipiente de mediçáo e contém o produto a ser ensaiado. O cilindro interno rotatório gira sob uma velocidade angular constante. Esse cilindro fica unido pelo eixo de mediçăo a uma mola helicoidal cilíndrica, cujo o desvio constitui uma medida do momento de torçăo (M). Através desse valor calculou-se a tensao de cisalhamento $(\tau$ ) e o gradiente de cisalhamento (D), segundo as formulas:

\section{- Tensfo de cisalhamente ( $\tau$ )}

$$
\tau=\mathrm{M} / 2 . \pi \cdot 1 . \mathrm{r}^{2}
$$


onde: $\mathbf{M}=$ momento de torfăa;

$r=$ raio do cilindro interno;

1 = altura do cilindro interno;

Unidade de $\tau=\operatorname{dina} / \mathrm{cm}^{2}$

\section{- Gradiente de cisalhamento}

$$
D=\left(\omega \cdot R^{2} \cdot 2\right) /\left(R^{2}-r^{2}\right)
$$

onde: $\omega=$ velocidade angular,

$\mathrm{R}=$ raio do cilindro externo;

$r=$ raio do cilindro interno;

Unidade de $\mathrm{D}=\mathrm{s}^{-1}$

- Viscosidade

$$
\eta=\tau / D
$$

\section{Unidade de $\eta=$ cPoise}

As viscosidades foram medidas utilizando-se das combinafőes de cilindros bIC/SI, que são adequadas para produtos de média viscosidade.

Uma vez obtidos os dados numéricos pelos testes reológicos, traçou-se a curva de histerese caracteristica da amostra O resultado é uma figura fechada e irregular (Reograma), cuja área tracuz a tixotropia da amostra testada. Os gráficos obtidos relacionam os valores de tensáo de cisalhamento no eixo das abscissas e os valores de gradiente de cisalhamento no eixo das ordenadas. 


\subsubsection{Padronizaçăo da metodologia in vitro para os extados de liberaçăo e penetraçăo} transcutanea dos corticosteróides contidos nas formulaçôes desenvolvidas

\subsubsection{Célula de difusão in vitro}

Foram projetados três modelos diferentes de célula de difusăo em sistema estático. As células $n^{\circ} 1$ e $n^{\circ} 2$ foram confeccionadas em vidro PIREX e acrilico. A célula no 3 é feita em acrflico, e representa um modelo de dissoluçáo da Farmacopéia Norte-Americana (89). Na Tabela 3 encontram-se descritas as dimensōes, a capacidade e demais caracteristicas das células de difusáo projetadas. As figuras 8, 9 e 10 ilustram com detalhes estas células de difusáo.

Tabela 3 - Características das células de difusão projetadas.

\begin{tabular}{|c|c|c|c|}
\hline \multirow{2}{*}{ Caracteristicas } & \multicolumn{3}{|c|}{ Céhula de Difusfo } \\
\hline & $n^{0} 1$ & $\mathrm{n}^{\circ} 2$ & $\mathbf{n}^{\circ} 3$ \\
\hline $\begin{array}{l}\text { Volume do compartimento } \\
\text { receptor (mL) }\end{array}$ & 300 & 30 & 300 \\
\hline $\begin{array}{l}\text { Área disponfvel para a difusfo } \\
\text { (cm²) }\end{array}$ & 8,04 & 3,80 & 8,04 \\
\hline Sistema de agitaçđo & $\begin{array}{l}\text { Agitador magnetico } \\
\text { (6mm × 20mm) }\end{array}$ & $\begin{array}{l}\text { Agitador magnético } \\
\text { (3mm x 10 } 10 \mathrm{~mm})\end{array}$ & $\begin{array}{l}\text { Agitador externo pá } \\
\text { (15mm x 55mm) }\end{array}$ \\
\hline Sistema de difusæo & estático & est ticico & estático \\
\hline
\end{tabular}




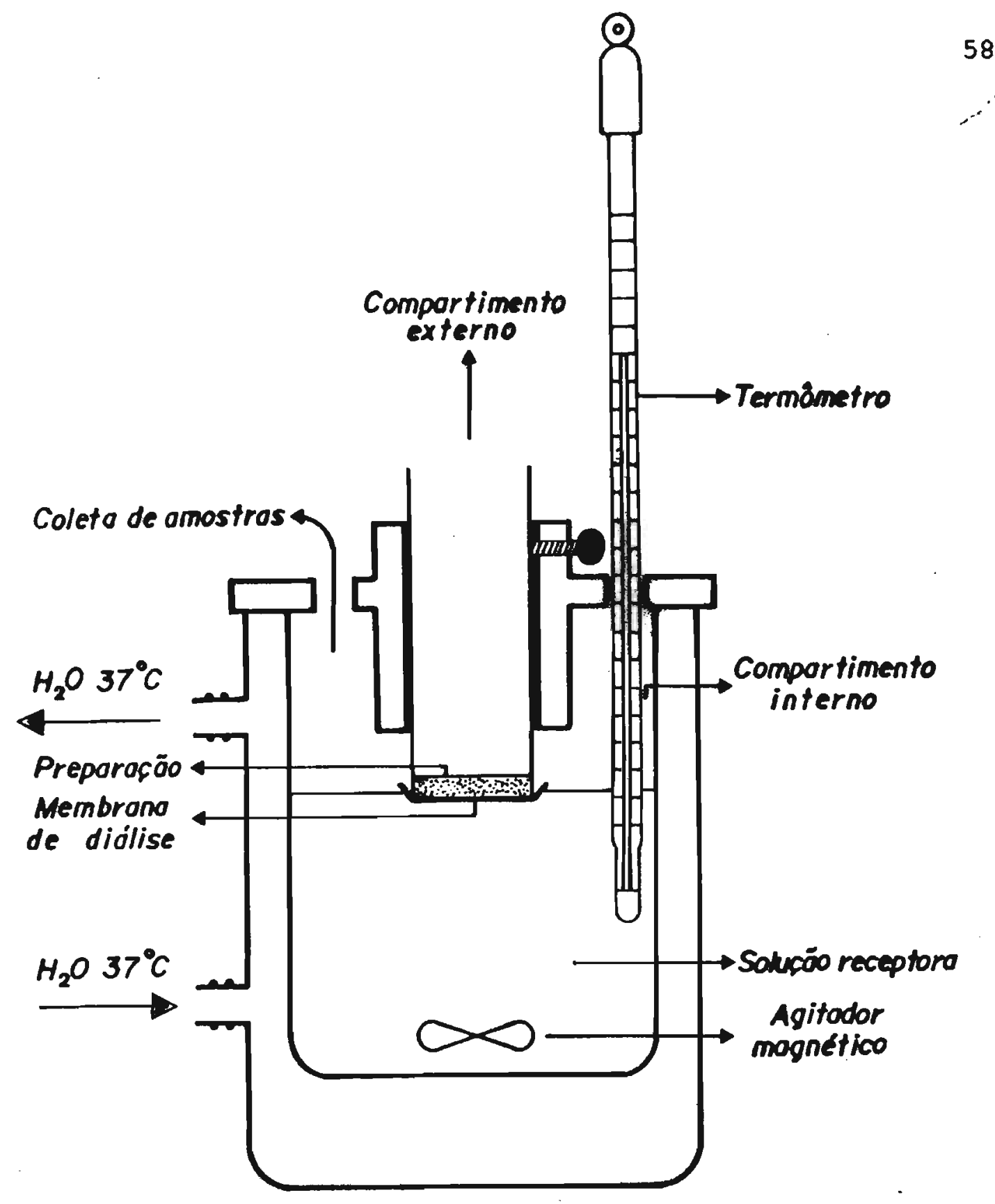

Figura 8: Célula de difusáo in vitro $\mathrm{n}^{\circ} 1$, baseada nos modelos de TURAKRA et al. (129) • BADRA et al. (4). 


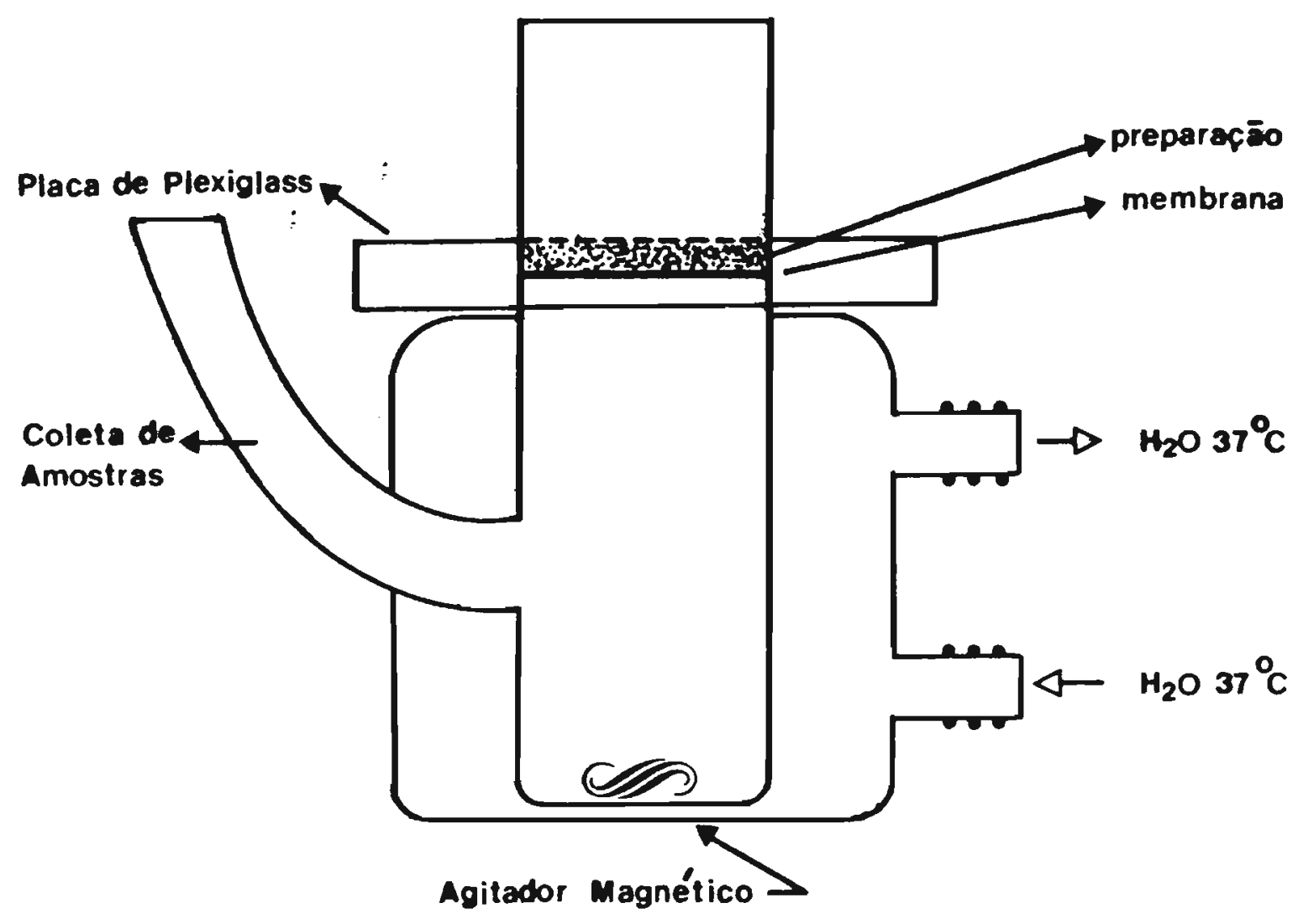

Figura 9: Célula de difusấo in vitro no 2, baseada no modelo da célula de FRANZ modificada (34). 


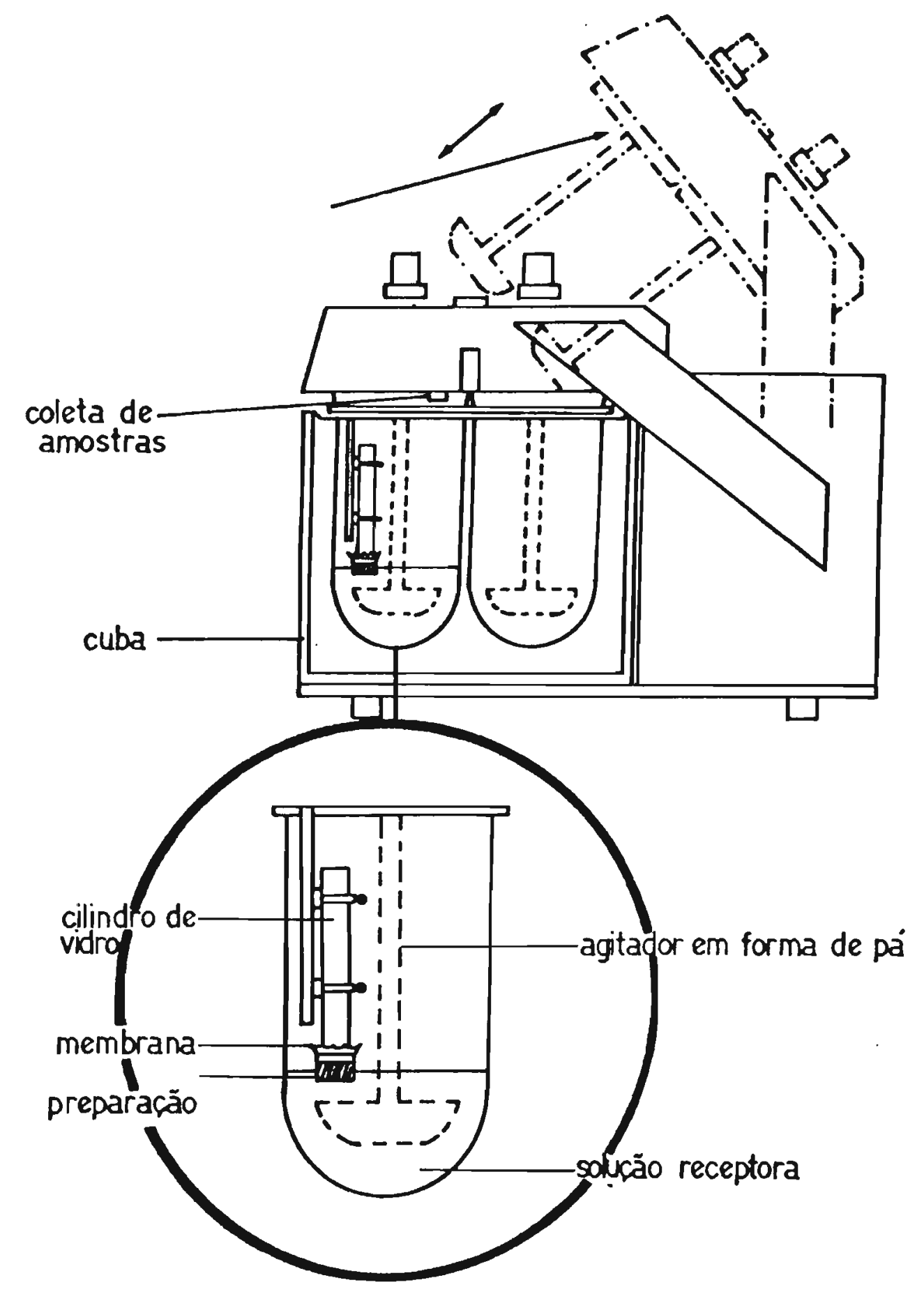

Trgura 10: Célula de difusto in vitro I0 3, baseada no modelo da Farmacopéia Norte -Americana (89). 
Os parametros, descritos a seguir, foram avaliados quando da eleiçáo do modelo de célula de difusão in vitro que mais se adequasse aos propósitos do trabalho, como:

\section{a) Verificação do tempo e uniformidade de agitação no compartimento das cétulas de difusto}

Para esta avaliaçáo foi empregado o método proposto por GUMMER et al. (42). Foram colocados $300,0 \mathrm{~mL}$ de água destilada nas células $\mathrm{n}^{\circ} 1$ e $\mathrm{n}^{\circ} 3$, e $30,0 \mathrm{~mL}$ na célula $\mathrm{n}^{\circ} 2$, juntamente com um cristal de permanganato de potássio. As células $n^{\circ} 1$ e $n^{\circ} 2$ eram providas de uma barra magnética para agitação, e a célula de $n^{0} 3$ foi agitada por meio de um agitador externo em forma de pá, o qual girava em uma velocidade constante de $100 \mathrm{rpm}$. $O$ agitador magnético, por sua vez nåo fornecia o número exato de rotą̧øes por minuto dados pela barra magnética

A uniformidade da coloraçáo violeta resultante da dissoluçáo do cristal de permanganato de potássio foi empregado como parâmetro para verificar visual e qualitativamente - grau de agitação. Considerou-se uma homogeneizaça instantanea e adequada quando o cristal dissolveu-se e a coloração da fase receptora apresentou-se completamente uniforme dentro de 30 segundos.

\section{b) Controle de Temperatura}

Como pode ser verificado nas figuras 8,9 e 10, as células de difusáo projetadas eståo submetidas a banhos termostatizados para mamutenfăo do sistema termperatura de $37{ }^{\circ} \mathrm{C}$. O controle desta temperatura foi realizado através de medidas da temperatura da soluça receptora durante um período de 10 horas de fincionamento do sistema 


\subsubsection{Solufáo receptora}

Utilizou-se como fase receptora trmpåo fosfato isotónico a pH $=7,4$. No sentido de otimizar esta fase receptora para os testes in vitro, ou seja, para garantir perfeitas condiçoes de solubilizą̧́o e difusáo dos corticosteróides através das membranas, também foi testado o mesmo tampão acrescido de polietilenoglicol-20-cetil éter a $0,5 \% \mathrm{p} / \mathrm{v}(2,71)$. A contaminą̧áo foi evitada adicionando-se $0,01 \% \mathrm{p} / \mathrm{v}$ de timerosal (69).

4.2.2.2.1. Determinaça do coeficiente de solubilidade dos acetatos dehidrocotisona e de dexametasona, da triamcinolona-acetonida e da desonida nas duas fases receptoras.

O método utilizado foi o proposto por MAITANI et al. (66). Um excesso de cada corticosteróide $(500,0 \mathrm{mg})$ foi adicionado em $300,0 \mathrm{~mL}$ de cada soluçáo receptora a ser testada, em um copo de dissolução descrita pela Farmacopéia Norte-Americana (89). O sistema foi agitado a $100 \mathrm{rpm}$ e mantido a $37^{\circ} \mathrm{C}$ por 24 hs. Após este periodo filtrou-se a dispersfo em membrana filtrante de $0,5 \mathrm{~mm}$, desprezando-se os primeiros $20,0 \mathrm{~mL}$, para evitar o risco de adsorçáo dos corticosterbides na membrana $O$ filtrado obtido foi diluído 1:100 com a respectiva soluçáo receptora no caso dos acetatos de hidrocortisona e de dexametasong, da triamcinolonaacetonida, e da desonida em soluf̧a receptora sem tensoativo. O filtrado com desonida em soluçáo receptora com tensoativo foi diluído 1:1000 com a respectiva fase receptora Após as diluiçסes apropriadas, foram efetuadas as determiną̧øes das concentraçes de saturąa dos corticosteróides por CLAE. 


\subsubsection{Membranas}

Foran empregadas uma membrana sintética acetato de celulose e uma natural (pele dissecada do abdômen de camundongo sem pêlo) nos estudos in vitro de liberafăo o penetraçăo transcutanea, respectivamente.

A membrana de acetato de celulose sofreu prévio tratamento em água destilada a 100 ${ }^{\circ} \mathrm{C}$ por 5 minutos, para remoçáo de impurezas. Foi mantida em água destilada, a $4{ }^{\circ} \mathrm{C}$ até $\mathrm{o}$ momento do uso. Pedafos de aproximadamente $6 \mathrm{~cm} \times 6 \mathrm{~cm}$ foram cortados e adaptados na célula de difusåo in vitro.

A membrana natural foi obtida por dissecação da pele abdominal de camundongos machos sem pêlo, após sacrifícá-los por asfixia com éter. A superffcie da pele foi limpa com algodåo embebido em etanol, e extraidas com auxílio de tesoura e pinça para dissecação. Retirouse o tecido subcutâneo e gorduroso presente abaixo da derme, e certificou-se da integridade da pele, ou seja, se esta apresentava-se livre de qualquer tipo de lesฐ̃o ou alteraçøes. As amostras de pele dissecadas foram embrulhadas em folhas de papel alumínio e filme plástico, congeladas e utilizadas, no máximo, 24 horas depois. Quando do seu uso, essas amostras de pele foram descongeladas naturalmente a temperatura ambiente, e colocadas nas células de difusáo in vitro.

\subsubsection{Padronização da metodologia anahtica para determinaç⿰㐅̆o de corticosteroldes por ClaA}

Foram padronizadas metodologias para análise por CLAE, dos seguintes corticosteróides: acetatos de hidrocortisona e de dexametasona, desonida, e triamcinolonaacetonida, baseando-se no método proposto por TOOTHAKER et al. (127). 


\subsubsection{Condiços cromatográficas}

Para a definiçào dos parâmetros cromatográficos, tais como comprimento de onds, composiçăo da fase móvel e atenuaçào, procedeu-se a cromatografia de amostras de cada uma das soluçôes estoques descritas no item 4.1.1. As condiçðes estabelecidas foram as seguintes:

Fase móvel: metanol: água (60:40);

Fluxo da fase móvel: $1,0 \mathrm{~mL} / \mathrm{min}$;

Comprimento de onda: $254 \mathrm{~mm}$;

Atenuação: 0,02 AUFS;

Volume de injeção: $20,0 \mu \mathrm{L}$.

Uma vez que sempre analisaríamos os vários corticosteróides em separado, utilizamos um como padra interno do outro da seguinte forma:

- Desonida (200 ng): padrăo interno para o acetato de dexametasona;

- Acetato de dexametasona (400 ng): padrão interno para a desonida, acetato de hidrocortisona e triamcinolona-acetonida

Para a obtençáo da fase móvel utilizou-se água e metanol previamente filtrados em sistema "Millipore". Ap6s a mistura das quantidades adequadas de metanol e água, a soluḉ̋ obtida foi deaerada sob sonicafáo por 10 minutos, seguido de agitafáo sob vácuo por igual período de tempo. 


\subsubsection{Procedimentos de extraço}

Amostras de $1,0 \mathrm{~mL}$ da soluçato receptora dos experimentos in vitro foram transferidas para um tubo de extracáo de $13 \times 100 \mathrm{~mm}$ dotado de tampa esmerilada, e acrescidos de $100,0 \mu \mathrm{L}$ de soluçấ estoque de padrăo interno. A extraçăo foi realizada com $6,0 \mathrm{~mL}$ de

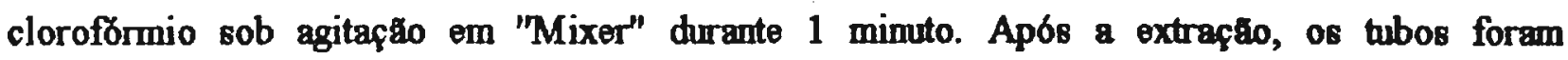
centrifugados a $2000 \mathrm{rpm}$ por 10 minutos, para ocorrer a separafá das fases. A fase aquosa foi retirada por meio de pipeta de polietileno e desprezada A fase organica foi transferida para tubos cónicos, sendo entáo o solvente evaporado sob fluxo de ar. O resíduo seco, assim obtido, foi ressuspenso em 100,0 $\mu \mathrm{L}$ da fase móvel sob agitą̧̃o durante 20 segundos em "Mixer". Após isto, procedia-se imediatamente à cromatografia da amostra. A figura 11 mostra esquematicamente o procedimento de extraçăo para análise dos corticosteróides na soluçấo receptora.

\subsubsection{Curva padråo de calibracáo}

Triplicatas de quantidades conhecidas de solução estoque dos acetafos de hidrocortisona e de dexametasona, desonida e triamcinolona-acetonida, variando de $5 \mathrm{ng}$ a $800 \mathrm{ng}$ foram adicionadas no branco da solução receptora (tampæo fosfato isotónico acrescido de $0,5 \%$ p/v de polietilenoglicol-20 cetil éter), juntamente com os respectivos padróes internos. Ap6s extraçáo e cromatografia, mediram-se as alturas dos picos correspondentes a cada corticosteróide (h), e dividiram-se esses valores pelas alturas respectivas dos padroes internos $\left(h_{\text {pi }}\right)$, obtendo-se assim os valores da relaçáo $R=h / h_{p i}$. A curva de calibrafáo foi obtida pela projeçá, no eixo das abcissas (X), dos valores das concentrafoes de corticosterbides (ng/mL); e, no eixo das ordenadas $(y)$, dos três valores de $\mathrm{R}$ referentes aos três cromatogramas obtidos para cada concentrafaro. 


\subsubsection{Verificação da eficiência do processo de extrą̧ - Determinacăo da recupe-} racåo relativa

Para verificą̧̃o da porcentagem de recuperaça relativa, quantidades das soluçðes estoques, referentes a quatro pontos da curva de calibraçåo, foram pipetadas para tubos cónicos, acrescidos de padra interno, e secas sob fluxo de ar. O residuo obtido foi ressuspenso na fase móvel e cromatografado. A relą̧áo entre a altura do padrăo e a altura do pico do padrắ interno foi comparada com a mesma relaçăo referente a curva extraida, e determinaram-se as porcentagens de recuperaçán relativa para os quatro pontos da curva extraída 
Amostra de 1,0 mL da soluçăo receptora

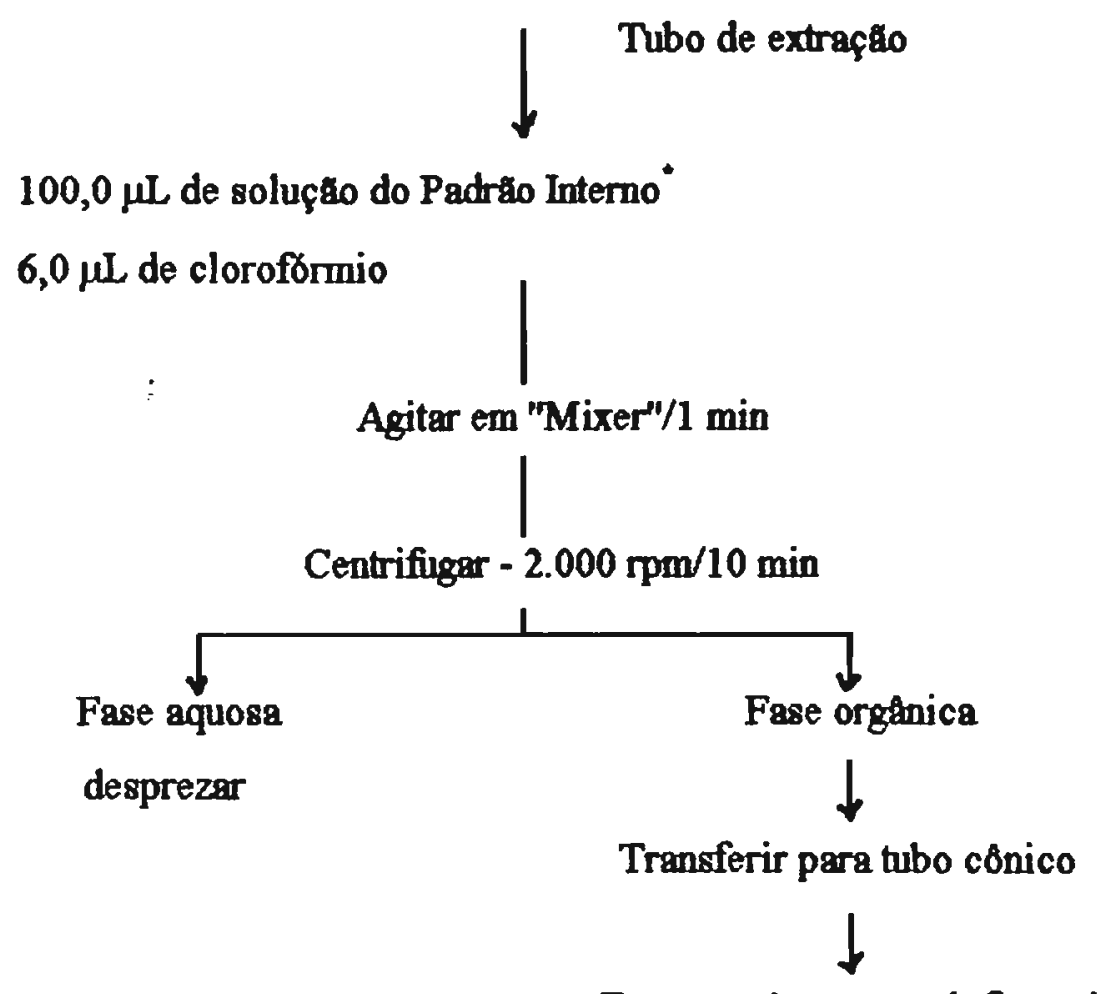

Evaporar à secura sob fluxo de ar

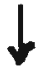

Ressuspender em 100,0 $\mu \mathrm{L}$ da fase móvel

Agitar em "Mixer"/20 segundos

$\downarrow$

Cromatografar

- Análise de triamcinolona-acetonida, desonida e acetato de hidrocortisona - Padráo interno Soluça acetato de dexametasona a 4,0 $\mu \mathrm{g} / \mathrm{mL}$.

Análise de acetato de dexametasona - Padrto interno - Soluço de desonida a 2,0 $\mu \mathrm{g} / \mathrm{mL}$

Figura 11 - Fluxograma referente ao processo de extrafăo para a determinaça dos corticosteróides na soluçăo receptora 
4.2.3.5. Determinacao por CLAE da quantidade de corticosterbides nas formulaçes desenvolvidas

A metodologia empregada foi a mesma para todos os corticosteróides, procedendo-se da seguinte maneira:

- Quantidades de géis contendo uréia ou lecitina referentes a 100,0 mg de corticosteróide foram pesadas em béquer de $25 \mathrm{~mL}$, dissolvidas em $15,0 \mathrm{~mL}$ de metanol e transferidas para um balão volumétrico de $50 \mathrm{~mL}$, onde completou-se o volume com metanol. Da soluçåo obtida, pipetaram-se 200,0 $\mu \mathrm{L}$ para um tubo cónico, acrescentaram-8e $100,0 \mu \mathrm{L}$ da soluçáo estoque do respectivo padrá interno, e secou-se sob fluxo de ar. O resíduo seco obtido foi ressuspenso em $100,0 \mu \mathrm{L}$ da fase móvel e cromatografado.

\subsubsection{Determinação por CLAE da quantidade de corticosteróide retida na pele de} camundongos sem pêlo nos experimentos in vitro

A extrafáa dos corticosteróides retidos na pele animal foi baseada no método proposto por SASAKI et al. (102) e TAUBER et al. (122). Decorridas 24 horas de experimento in vitro, a pele de camundongo sem pélo foi retirada do aparelho de difusåo. A superficie da pele sobre a qual foi depositada a preparaçá foi limpa por meio de algodão embebido em metanol, objetivando retirar o excesso de produto da pele. Após este procedimento recortou-se a área da pele exposta à difusáo, picotou-se, e os fragmentos obtidos foram transferidos para um tubo de plástico contendo $25,0 \mathrm{~mL}$ de metanol. Os fragmentos de pele foram triturados em homogeneizador de tecidos até total dilaceraça da pele. Após isto, a suspensáo obtida foi submetida à sonicaçáo em ultrassom de alta frequência curante 45 segundos, em intervalos de 15 segundos, para ocorrer o rompimento das células. O produto obtido foi filtrado em papel de filtro para um baláo volumétrico de $50 \mathrm{~mL}$, completou-se o volume e agitou-se. Alíquotas de 1,0 mL foram transferidas 
para um tubo cónico acrescidas de $100,0 \mu \mathrm{L}$ da soluç̧o de padrăo interno e secas sob fluxo de ar. O residuo foi ressuspenso na fase móvel e cromatografado.

\subsubsection{Determinaçăo do coeficiente de particăo óleo/água dos corticosteróides emprega- dos nas formulaçðes}

Para a determinaçáo do coeficiente de partiçá óleo/água da desonida, triamcinolonaacetonida e acetatos de hidrocortisona e de dexametasona foi empregado o método proposto por OSTRENGA et al. (85).

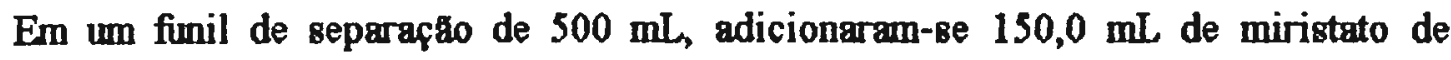
isopropila contendo $0,02 \mathrm{mg} / \mathrm{mL}$ de corticosteróide, e $150,0 \mathrm{~mL}$ de água. Vedou-se a tampa do funil com teflon e agitou-se em agitador mecânico horizontal, em $220 \mathrm{ciclos} / \mathrm{min}$ durante 24 horas na temperatura ambiente. Após este período, separaram-se as fases, e analisou-se, individualmente o conteúdo de corticosteróide. Os coeficientes de partiçáo óleo/água foram calculados como sendo a relaçáo da concentraçáo de corticosteróide na fase oleosa (miristato de isopropila) e na água

4.2.5. Condução dos experimentos de liberação e penetração trancutanea In vitro, utillzando a céłula de difusăo $n^{\circ} 3$

As membranas foram esticadas em uma das extremidades do cilindro de vidro por meio de anel de borracha Quando utilizou-se a pele de camundongo sem psిlo, tomou-se o cuidado para que o lado inferior da derme ficasse em contato com a soluçáo receptora Cerca de $1,5 \mathrm{~mL}$ das preparaçes, ainda a $4^{\circ} \mathrm{C}$, foram pipetadas sobre a epiderme. A preparafăo ainda fluida foi espalhada uniformemente sobre toda a área da membrana, evitando-se a formafăo de bolhas. Após atingir a temperatura ambiente (alguns segundos depois) o cilindro de vidro foi acoplado à célula de difusấ, a qual previamente foi equilibrada a $37^{\circ} \mathrm{C}$, e ajustado de maneira que a extremidade 
que contem a membrana ficasse mergulhada, cerca de $2 \mathrm{~mm}$, na soluçáo receptora $O$ sistema de agitąáo foi acionado (100 rpm/min) e amostras de $2,0 \mathrm{~mL}$ da fase receptora foram coletadas nos tempos $0,2,4,6,8,10,12$ e 24 horas para a determinaçăo do conteúdo de corticosteróide liberado ou penetrado por CLAE. Para manter o volume constante, a cada coleta retornaram-8e 2,0 $\mathrm{mL}$ de soluçăo receptora nova

Quando do emprego da membrana natural, ap6s 24 horas de experimento, a área de pele exposta para a liberaça foi limpa, com algodáo embebido em metanol, recortada e analisada quanto ao conteudo de corticosteroide retido, conforme descrito no item 4.2.3.6.

Com relą̧áo as formulaçðes contendo lecitina, também foram realizados experimentos de penetraçáo e retençăo cutânea dos corticosteróides contidos nas formulą̧ðes sem lecitina

Os experimentos foram realizados em quadruplicatas para todas as formulą̧⿸e.

\subsubsection{Análise dos resultados}

Os dados de liberaça e penetraça transcutanea obtidos foram utilizados para calcular os parâmetros cinéticos tempo LAG e fluxo $(J)$ dos corticosteróides através das membranas. Para tanto, dois modelos cinéticos foram utilizados. O modelo HIGUCHI $(22,45,71$, $96,113)$ relaciona a quantidade de fármaco liberado ou penetrado versus a raíz quadrada do tempo. A interceptafáo no eixo das abcissas destas curvas, em regressáo linear, representou o tempo LAG em horasł̌r. $O$ fluxo (J) é dado pela inclinaffo da curva e foi expresso em $\mu \mathrm{g} / \mathrm{cm}^{2} /$ horas ${ }_{2}$ O segundo modelo empregado foi o de cinética de 1' ordem, onde o Log das quantidades de fármaco liberado ou penetrado é plotado contra o tempo (100). Os parłmetros $L A G$ e fluxo (J) foram expressos em horas e $\log \mu g / \mathrm{cm}^{2} /$ horas, respectivamente. 
5 - RESULTADOS 
5.1. DETERMINAÇÃO DAS PROPRILDADES FISICO-QUIMICAS DAS FORMULAÇOES

\subsubsection{Determinação do $\mathrm{pH}$}

Os valores de pH para as várias formulaçóes estão relacionados na Tabela 4.

Tabela 4 - Valores de pH das formulą̧óes de géis hidrófilos contendo uróia e lecitina.

\begin{tabular}{cc|c}
\hline \multicolumn{1}{c|}{ Formulaçóes $^{*}$} & & $\mathrm{pH}^{-}$ \\
\hline & $\mathrm{G}_{1}$ & $5,7( \pm 0,015)$ \\
Géis com uréia & $\mathrm{G}_{2}$ & $5,4( \pm 0,006)$ \\
$(\mathbf{n}=3)$ & $\mathrm{G}_{3}$ & $6,3( \pm 0,003)$ \\
& $\mathrm{G}_{4}$ & $6,3( \pm 0,003)$ \\
& $\mathrm{G}_{5}$ & $6,3( \pm 0,007)$ \\
Géis com lecitina & & \\
$(\mathbf{n}=3)$ & $\mathrm{L}_{1}$ & $5,9( \pm 0,033)$ \\
& $\mathbf{L}_{2}$ & $6,1( \pm 0,017)$ \\
& $\mathrm{L}_{3}$ & $6,1( \pm 0,017)$ \\
& $\mathbf{L}_{4}$ & $6,2( \pm 0,017)$ \\
& & \\
\hline
\end{tabular}

- A presença dos corticosteróides náo alterou os valores de $\mathrm{pH}$; os valores em parênteses representam os desvios padráo. 


\subsubsection{Determinação do comportamento reologico}

As figuras 12 e 13 ilustram os reogramas referentes ds formulaçøes desenvolvidas.

A Tabela 5 mostra os valores de viscosidade das formulacóes desenvolvidas, em uma mesma velocidade angular.

Tabela 5 - Valores de viscosidade das formulaçøes desenvolvidas.

\begin{tabular}{cc|c}
\hline \multicolumn{1}{c|}{ Fonmulaçбes } & Viscosidade (cPoise) \\
\hline \multirow{2}{*}{ Geis contendo uréia } & $\mathrm{G}_{1}$ & $63.261,32$ \\
& $\mathrm{G}_{2}$ & $76.680,38$ \\
& $\mathrm{G}_{3}$ & $90.099,45$ \\
& $\mathrm{G}_{4}$ & $92.016,46$ \\
& $\mathrm{G}_{5}$ & $95.431,41$ \\
& & \\
Geis contendo lecitina & $\mathrm{L}_{1}$ & $49.533,68$ \\
& $\mathrm{~L}_{2}$ & $55.593,28$ \\
& $\mathrm{~L}_{3}$ & $69.976,00$ \\
& $\mathrm{~L}_{4}$ & $99.684,50$ \\
\hline
\end{tabular}

- A presença dos corticosteróides nå alterou os valores de viscosidade. 


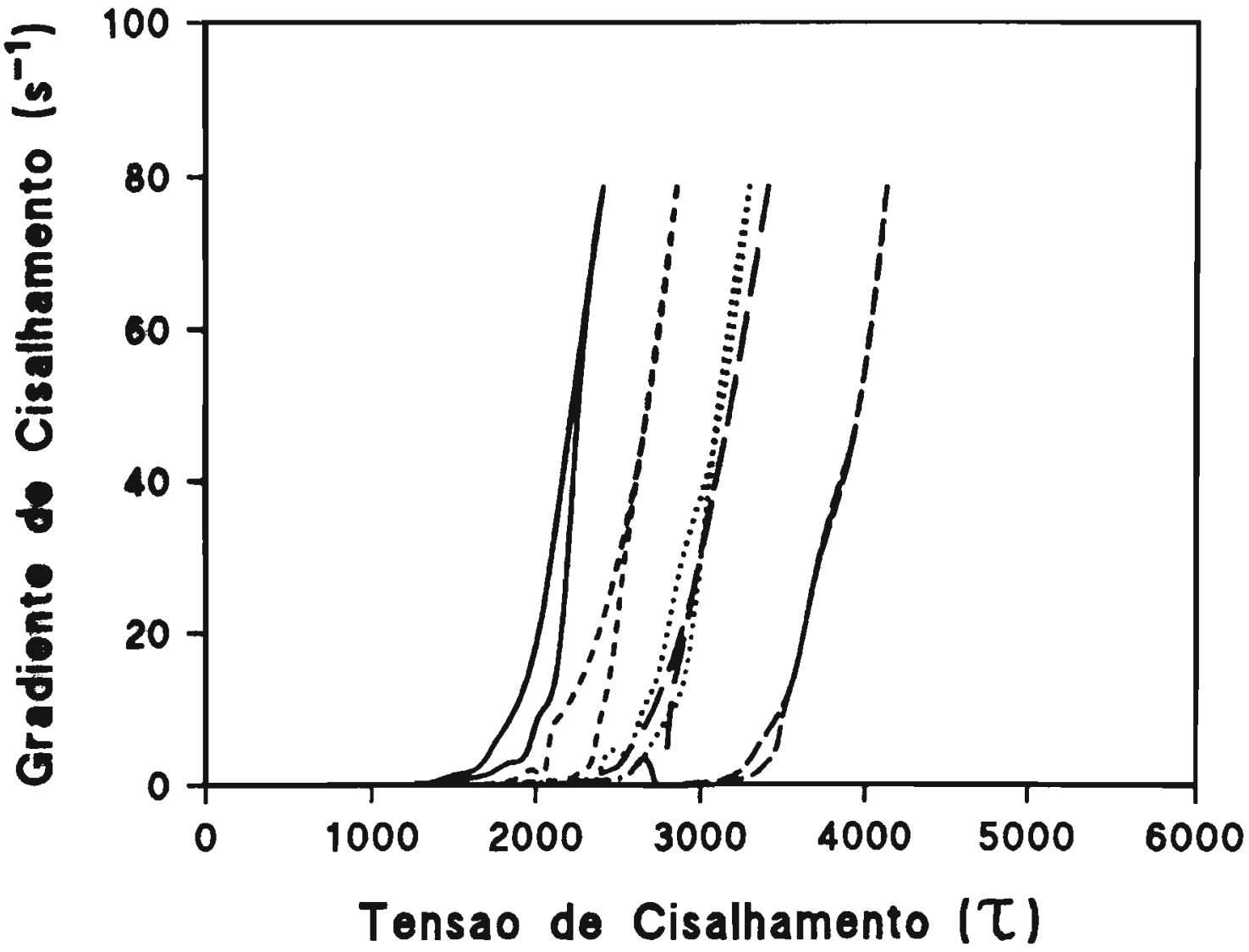

Área de Histerese:

$$
\begin{aligned}
& G_{1}=0,86 \mathrm{~cm}^{2} \\
& G_{2}=0,62 \mathrm{~cm}^{2} \\
& G_{3}=0,58 \mathrm{~cm}^{2} \\
& G_{4}=0,29 \mathrm{~cm}^{2} \\
& G_{5}=0,00 \mathrm{~cm}^{2}
\end{aligned}
$$

Figura 12 - Reogramas referentes aos géis hidrofilos contendo uréia 


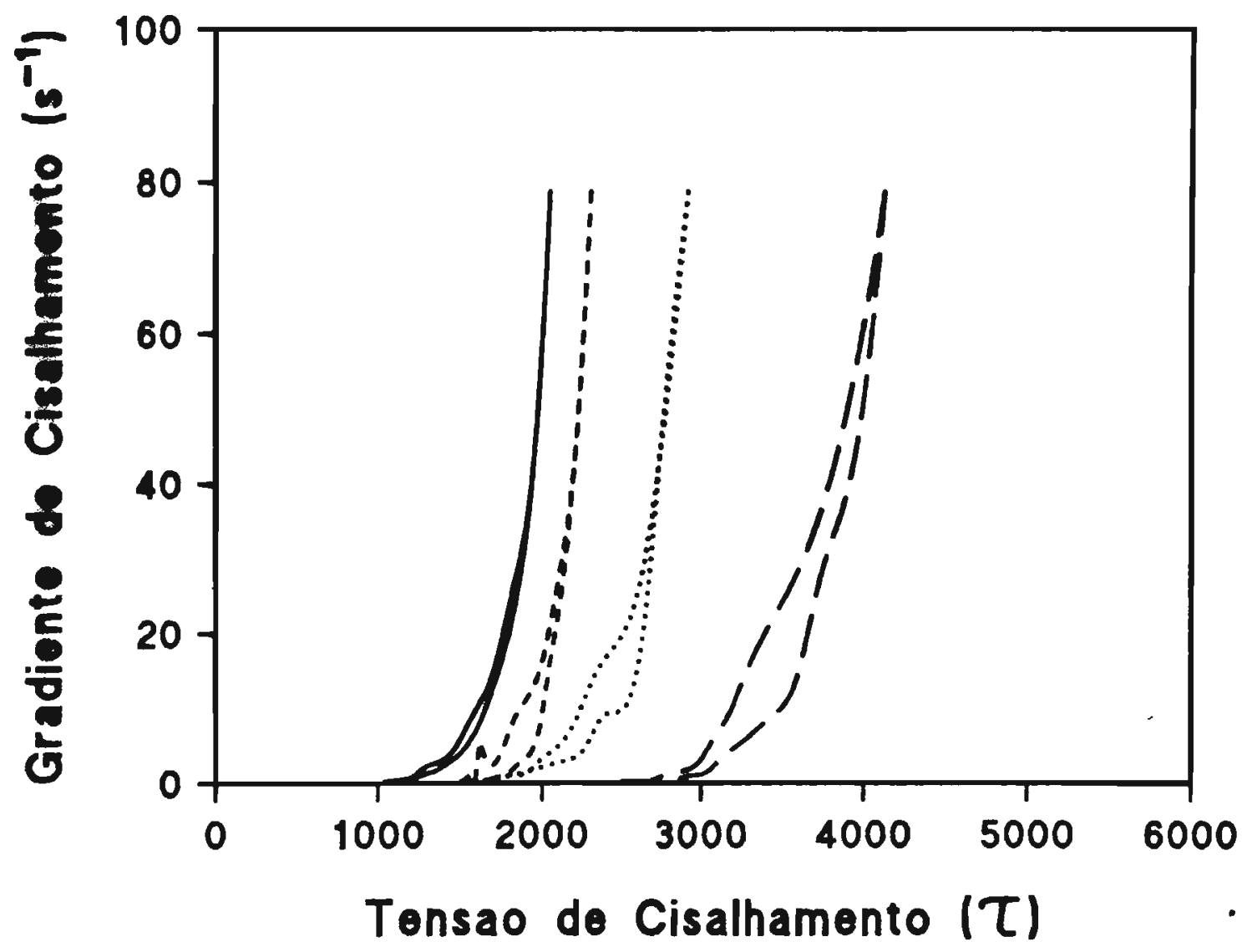

Área de Histerese:

$$
\begin{aligned}
& \mathrm{L}_{1}=0,00 \mathrm{~cm}^{2} \\
& \mathrm{~L}_{2}=0,15 \mathrm{~cm}^{2} \\
& \mathrm{~L}_{3}=0,33 \mathrm{~cm}^{2} \\
& \mathrm{~L}_{4}=2,05 \mathrm{~cm}^{2}
\end{aligned}
$$

Tigura 13 - Reogramas referentes aos geis hidrofilos contendo lecitina 
5.2. PADRONIZAÇÃo DA METODOLOGIA IN VTRO PARA OS ESTUdOS DE LIBERAÇÃO E PENETRAÇAO PERCUTÂNEA DOS CORTICOSTERómES CONTIDOS NAS FORMULAÇOES DESENVOLVIDAS

\subsubsection{Células de difusăo in vitro}

Os resultados dos parâmetros mencionados no item 4.2.2.1. estăo relacionados na Tabela 6.

Tabela 6 - Avaliaçáo das células de difusåo projetadas.

\begin{tabular}{|c|c|c|c|}
\hline \multirow{2}{*}{ Parâmetros } & \multicolumn{3}{|c|}{ Célula de difušro } \\
\hline & $n^{\bullet} 1$ & $n^{\bullet} 2$ & $n^{\bullet} 3$ \\
\hline Tempo de agitação & 30 seg. & 30 seg. & $<30$ seg. \\
\hline $\begin{array}{l}\text { Manutenç8̃o da temperatura em } \\
\qquad 37^{\circ} \mathrm{C} / 10 \mathrm{~h}\end{array}$ & Variaçช̊o & Variaçช̃o & Constante \\
\hline Uniformidade da agitação & Uniforme & $\begin{array}{l}\text { Näo uniforme no } \\
\text { braço coletor }\end{array}$ & Uniforme \\
\hline $\begin{array}{c}\text { Controle de velocidade de } \\
\text { agitação }\end{array}$ & sem controle & sem controle & $\begin{array}{c}\text { com controle (100 } \\
\mathrm{rpm})\end{array}$ \\
\hline
\end{tabular}


5.2.2. Determinactá dos coeficientes de solubilidade

A Tabela 7 mostra os valores de coeficiente de solubilidade dos corticosteroides nas fases receptoras testadas.

Tabela 7 - Coeficiente de solubilidade dos corticoster6des nas soluçбes receptoras testadas.

\begin{tabular}{c|c|c}
\hline \multirow{2}{*}{ Corticosteróides } & \multicolumn{2}{|c}{ Coeficiente de solubilidade (mg/L) } \\
\cline { 2 - 3 } & \multicolumn{2}{|c}{ Soluf̧̃o receptora } \\
\cline { 2 - 3 } & Sem tensoativo & Com tensoativo \\
\hline Acetato de Hidrocortisona & $1,034( \pm 0,606)$ & $81,22( \pm 2,349)$ \\
Acetato de Dexametasona & $15,60( \pm 0,586)$ & $74,76( \pm 2,126)$ \\
Desonida & $56,52( \pm 1,485)$ & $107,00( \pm 1,528)$ \\
Triamcinolona-acetonida & $16,54( \pm 0,378)$ & $45,76( \pm 1,141)$ \\
\hline
\end{tabular}

Os valores em parênteses representam os valores dedesvio padrăo referentes a três determiną̧̃oes. 


\subsection{PADRONIZAÇÃO DA METODOLOGIA ANALITICA PARA DETERMINAÇÃO DE CORTICOSTERÓDES POR CLAE}

\subsubsection{Condiçơes cromatográncas}

A determinaça dos acetatos de hidrocortisona e de dexametasona, desonida e triamcinolona-acetonida foi executada conforme método descrito em 4.2.3.1.

As figuras 14, 15, 16 e 17 mostram os cromatogramas referentes ao branco (Boluço receptora), branco adicionado de padróes e amostra, referentes aos corticosteróides emuregados.

\subsubsection{Curva padráo de calibraçăo}

Para a elaboração da curva padrão de calibração empregaram-se soluções padrões dos corticosteróides diluídas em soluçáo receptora (branco), conforme descrito no item 4.2.3.3. As diluiçסes forma realizadas em triplicatas. Os dados obtidos, mostrados nas Tabelas 8, 9, 10 e 11, permitiram a elaboraço das curvas de calibraça representadas pelas figuras 18, 19, 20 e 21. 


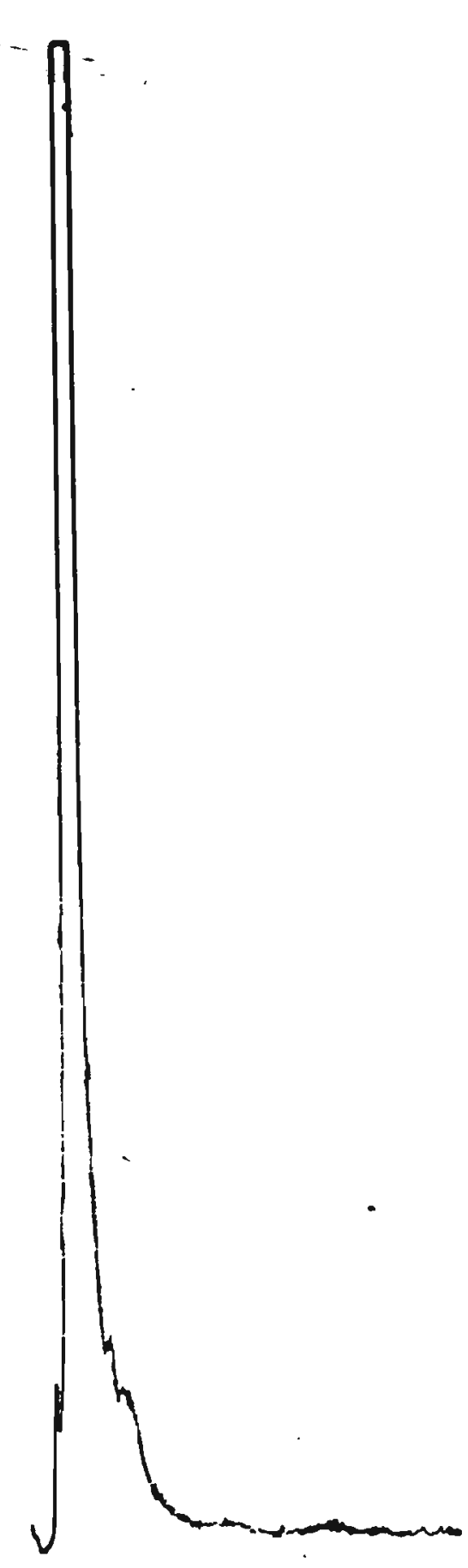

(a)

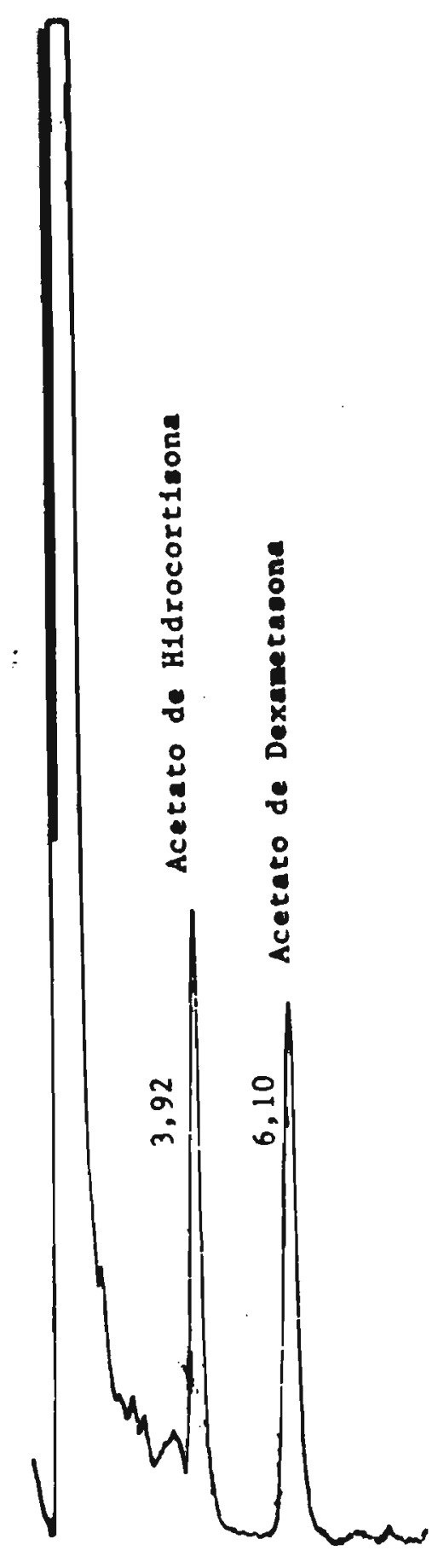

(b)

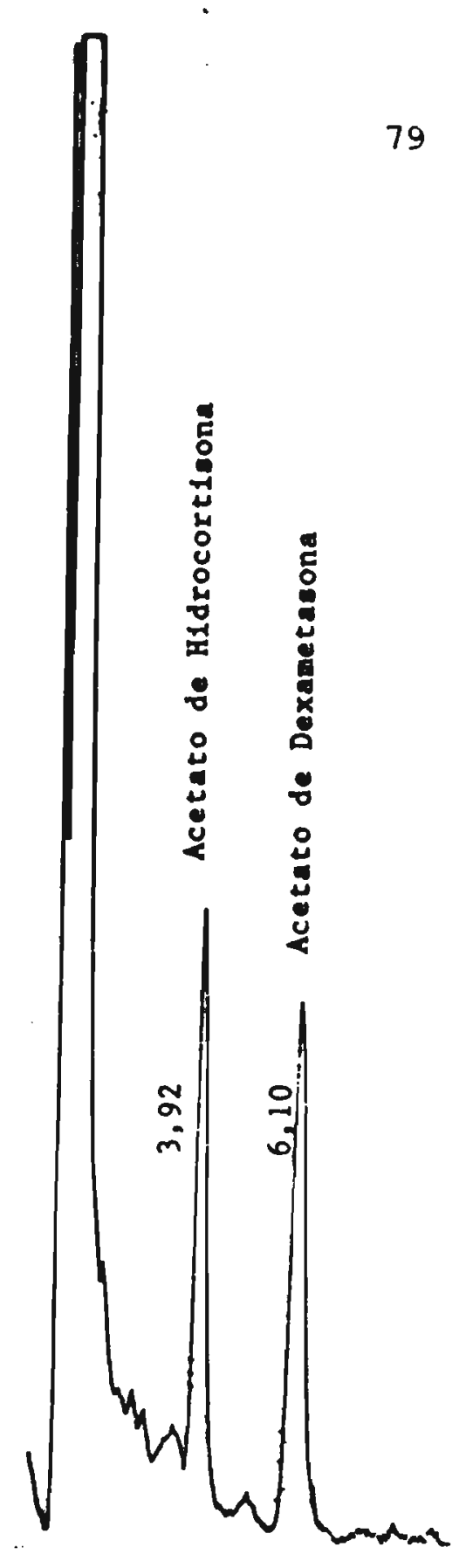

(c)

Figura 14 - Cromatogramas referentes ao branco (a), branco adicionado de padróea (b), e amostra (c) obtidos segundo as condiçøes cromatográficas descritas no item 4.2.3.1.; Concentraftio em ImL: $200,0 \mathrm{ng}$ de acetato de hidrocortisona e 400,0 ng de acetato de dexametasona (padrăo interno); Tempo de retençăo: acetato de hidrocortisona = 3, $92 \mathrm{~min}$ e acetato de dexametasona $=6,10 \mathrm{~min}$ 


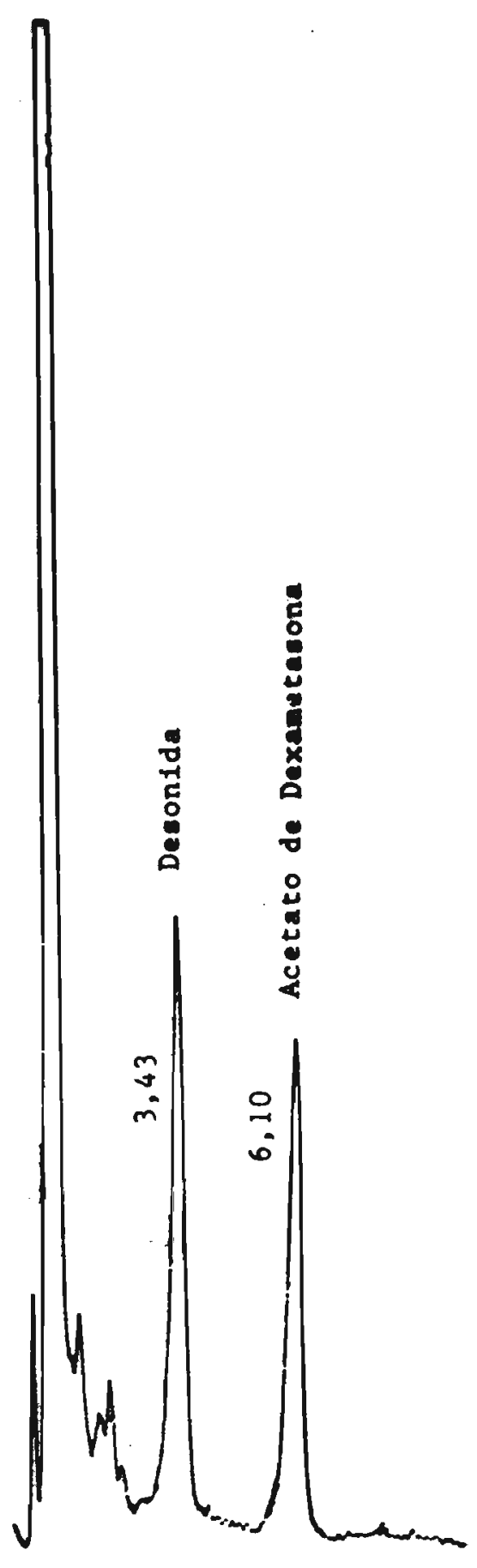

(a)

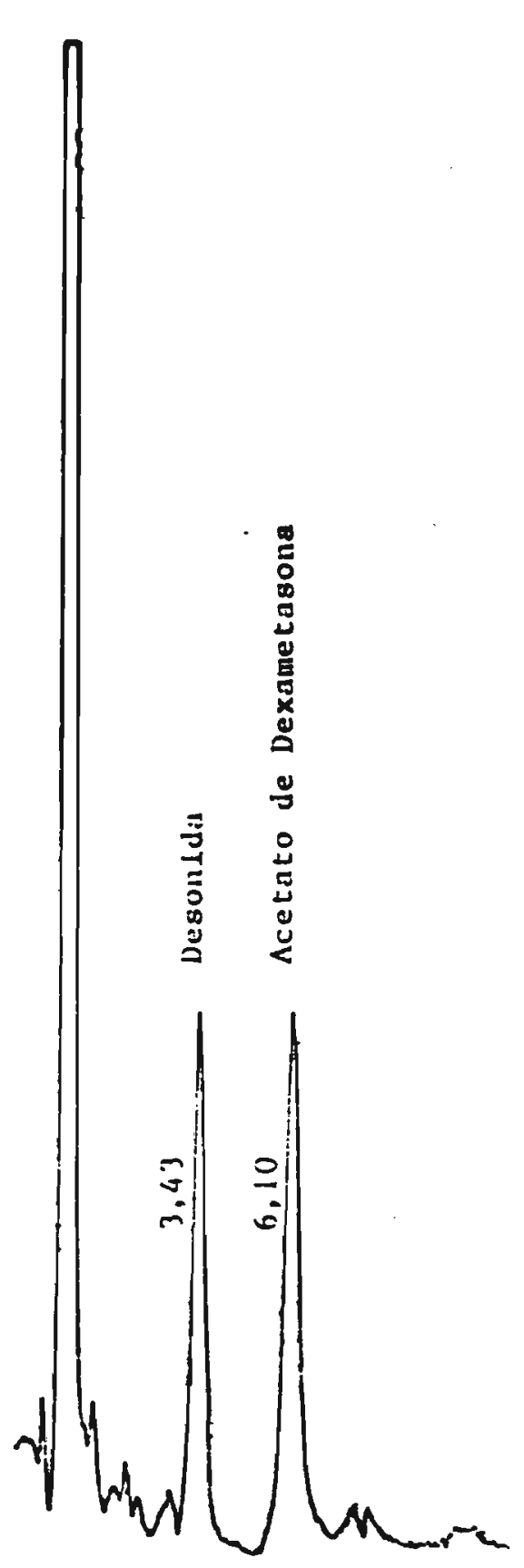

(b)

Figura 15 - Cromatogramas referentes ao branco adicionado de padróes (a) e amostra (b) obtidos

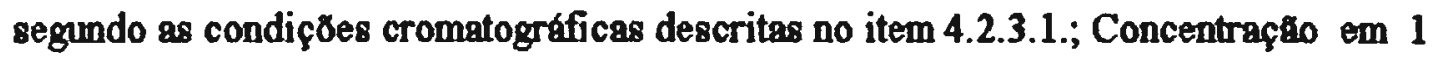
$\mathrm{mL}: 400,0 \mathrm{ng}$ de acetato de dexametasona e 200,0 ng de desonida (padrá interno); Tempo de retençáo: acetato de dexametasona $=6,10 \mathrm{~min}$ e desonida $3,43 \mathrm{~min}$ 


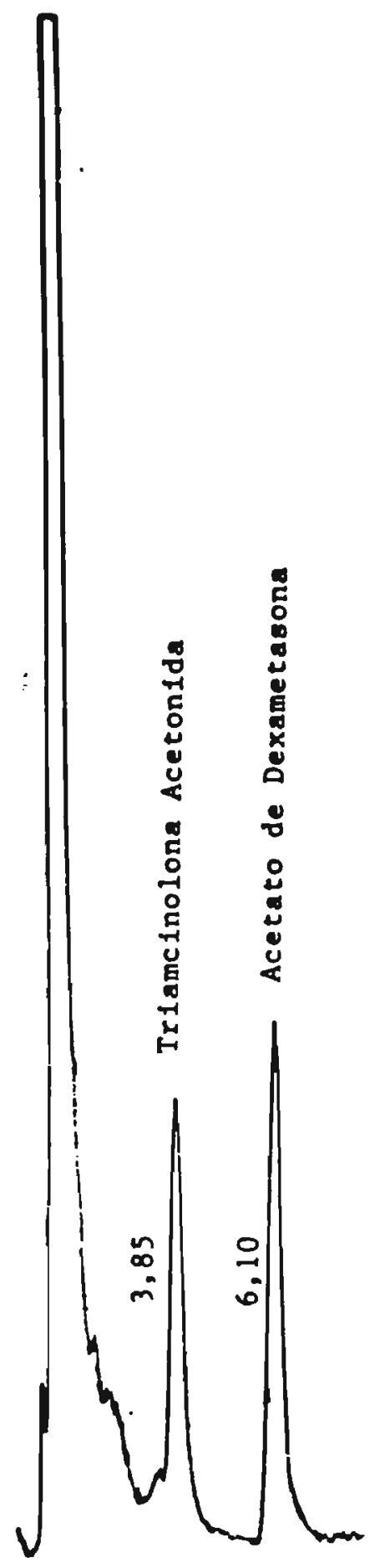

(a)

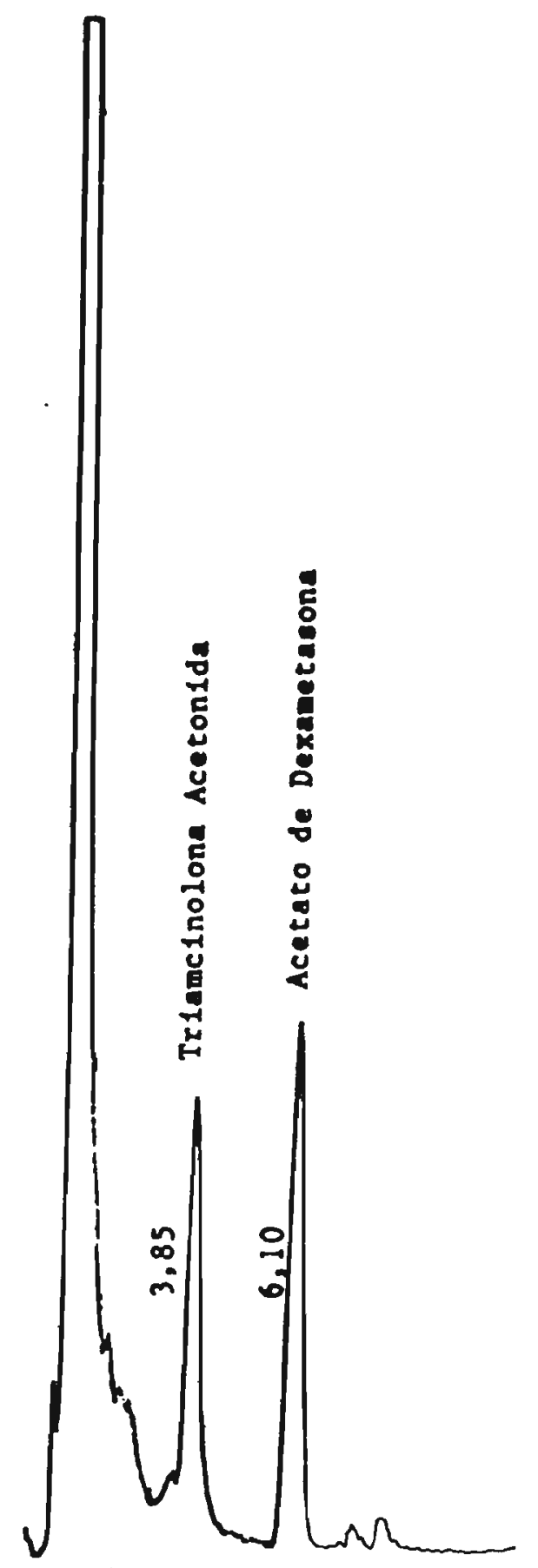

(b)

Hegura 16 - Cromatogramas referentes ao branco adicionado de padróes (a) e amostra (b) obtidos segundo as condiføes cromatograficas descritas no item 4.2.3.1.; Concentrafto em 1 $\mathrm{mL}: 200,0 \mathrm{ng}$ de triamcinolona-acetonida $4400,0 \mathrm{ng}$ de dexametasona acetato (padrao interno); Tempo de retençto: triamcinolona-acetonida $=3,85 \mathrm{~min}$ e dexametasona acetato $=6,10 \mathrm{~min}$ 


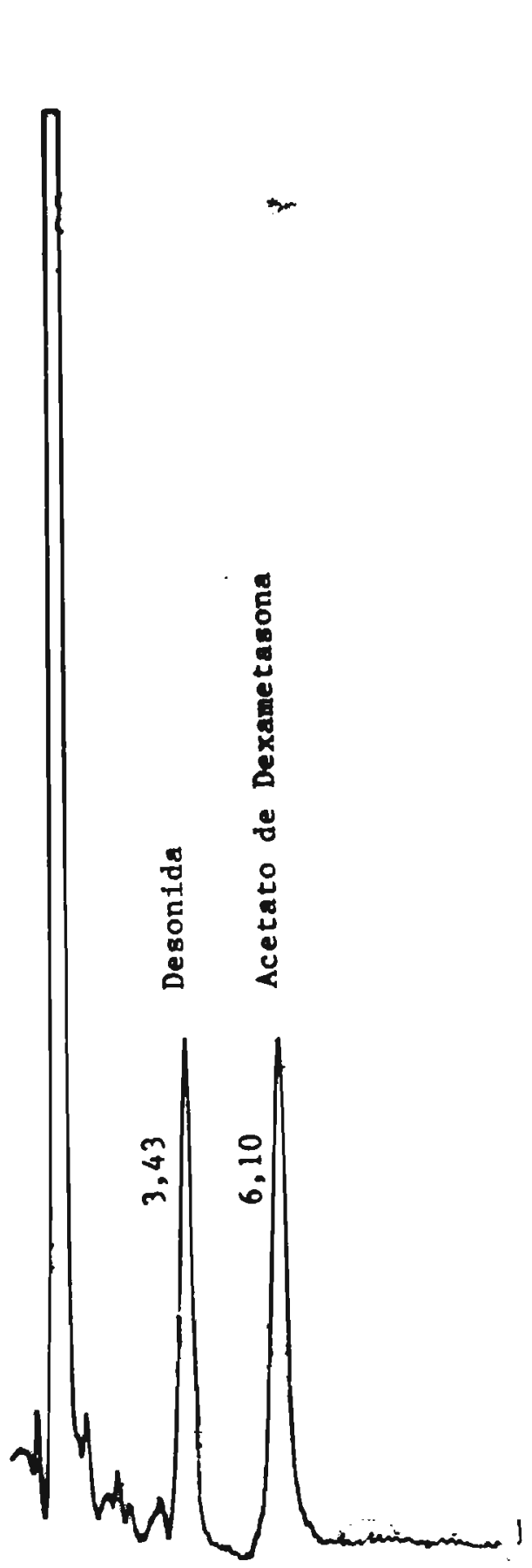

(a)

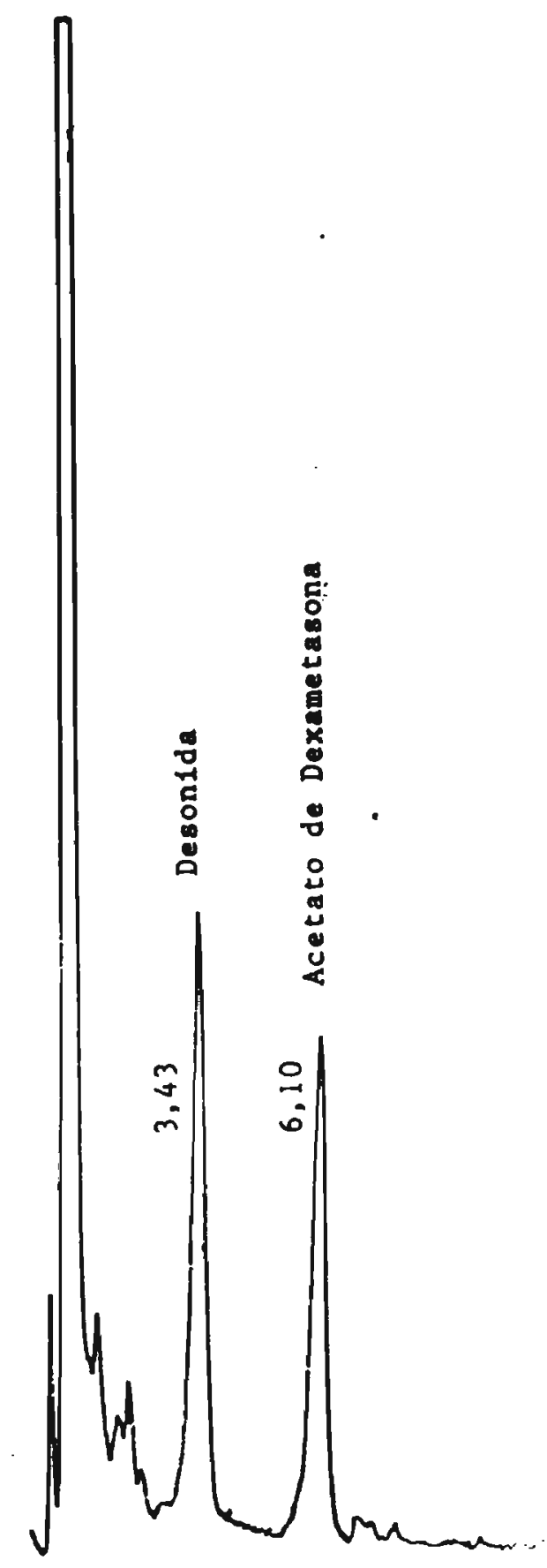

(b)

Fgura 17 - Cromatogramas referentes ao branco adicionado de padróes (a) e amostra (b) obtidos segundo as condiçøes cromatograficas descritas no item 4.2.3.1.; Concentrafăo em $1 \mathrm{~mL}: 200,0 \mathrm{ng}$ de desonida e $400 \mathrm{ng}$ de dexametasona acetato (padrio interno); Tempo de retençăo: desonida $=3,43 \mathrm{~min}$ e dexametasona acetato $=6,10 \mathrm{~min}$ 
Tabela 8 - Parâmetros analíticos obtidos para a elaboração da curva padrăo de calibraçáo para o acetato de hidrocortisona (AHC) utilizando o acetato de dexametasona (ADM) como padråo interno (P.I).

\begin{tabular}{|c|c|c|c|}
\hline \multirow{2}{*}{$\begin{array}{c}\text { Concentraçåo } \\
\text { (ng/mL) }\end{array}$} & \multicolumn{2}{|c|}{ Altura do Pico (cm) } & \multirow{2}{*}{$\mathbf{R}^{*}$} \\
\hline & AHC & P.I & \\
\hline \multirow{3}{*}{100} & 3,30 & 6,40 & 0,5156 \\
\hline & 3,20 & 6,30 & 0,5079 \\
\hline & 3,40 & 6,20 & 0,5484 \\
\hline \multirow{3}{*}{200} & 6,50 & 6,40 & 1,0317 \\
\hline & 6,60 & 6,30 & 1,0476 \\
\hline & 6,80 & 6,20 & 1,0625 \\
\hline \multirow{3}{*}{300} & 9,60 & 6,20 & 1,5484 \\
\hline & 9,90 & 6,30 & 1,5714 \\
\hline & 10,00 & 6,20 & 1,6129 \\
\hline \multirow{3}{*}{400} & 13,00 & 6,10 & 2,1311 \\
\hline & 13,20 & 6,20 & 2,1290 \\
\hline & 13,30 & 5,90 & 2,2542 \\
\hline \multirow{3}{*}{500} & 16,30 & 6,20 & 2,6290 \\
\hline & 15,90 & 6,30 & 2,5238 \\
\hline & 16,50 & 5,90 & 2,7966 \\
\hline
\end{tabular}

- Relaça entre as alturas do pico do AHC e do P.I 
Tabela 9 - Parametros analíticos obtidos para a elaboraf̧́o da curva padráo de calibraçăo para o acetato de dexametasona (ADM) utilizando a desonida (D) como padrao interno (P.I).

\begin{tabular}{|c|c|c|c|}
\hline \multirow{2}{*}{$\begin{array}{c}\text { Concentraç8o } \\
\text { (ng/mL) }\end{array}$} & \multicolumn{2}{|c|}{ Altura do Pico $(\mathrm{cm})$} & \multirow{2}{*}{$\mathbf{R}^{*}$} \\
\hline & ADM & P.I. & \\
\hline \multirow{3}{*}{50} & 0,90 & 4,70 & 0,1915 \\
\hline & 0,80 & 4,60 & 0,1739 \\
\hline & 0,70 & $4, \infty$ & 0,3830 \\
\hline \multirow{3}{*}{100} & 1,80 & 4,70 & 0,7381 \\
\hline & 1,60 & 4,50 & 0,3556 \\
\hline & 1,70 & 4,60 & 0,3696 \\
\hline \multirow{3}{*}{200} & 3,10 & 4,20 & 0,7381 \\
\hline & 3,50 & 4,50 & 0,7778 \\
\hline & 3,40 & 4,50 & 0,7556 \\
\hline \multirow{3}{*}{400} & 5,90 & 4,10 & 1,4390 \\
\hline & 6,10 & 4,30 & 1,4186 \\
\hline & 5,90 & 4,20 & 1,4048 \\
\hline \multirow{3}{*}{800} & 11,70 & 4,30 & 2,7093 \\
\hline & 11,40 & 4,10 & 2,7805 \\
\hline & 12,00 & 4,20 & 2,8571 \\
\hline
\end{tabular}

- - Relą̧áo entre as alturas do pico do ADM e do P.I 


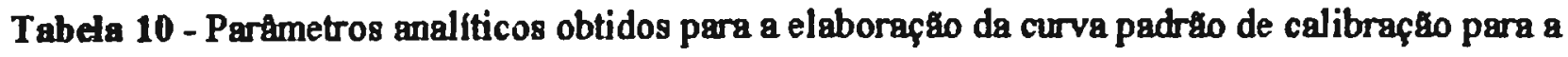
triamcinolona-acetonida (TA) utilizando o acetato de dexametasona (ADM) como padrăo interno (P.I.).

\begin{tabular}{|c|c|c|c|}
\hline \multirow{2}{*}{$\begin{array}{c}\text { Concentraçåo } \\
\text { (ng/mL) }\end{array}$} & \multicolumn{2}{|c|}{ Altura do Pico (cm) } & \multirow{2}{*}{$\mathbf{R}^{*}$} \\
\hline & $\mathrm{TA}$ & P.I & \\
\hline \multirow{3}{*}{25} & 0,70 & 6,10 & 0,1148 \\
\hline & 0,60 & 6,00 & 0,1000 \\
\hline & 0,80 & 6,50 & 0,1231 \\
\hline \multirow{4}{*}{50} & 1,30 & 6,50 & 0,2000 \\
\hline & 1,50 & 6,70 & 0,2239 \\
\hline & 1,40 & 6,60 & 0,2121 \\
\hline & 2,80 & 6,30 & 0,4444 \\
\hline \multirow{2}{*}{100} & 2,90 & 6,40 & 0,4531 \\
\hline & 2,60 & 6,10 & 0,4262 \\
\hline \multirow{4}{*}{200} & 5,10 & 6,50 & 0,7846 \\
\hline & 5,50 & 6,20 & 0,8871 \\
\hline & 5,20 & 6,10 & 0,8525 \\
\hline & 10,20 & 6,50 & 1,5692 \\
\hline \multirow[t]{2}{*}{400} & 11,00 & 6,20 & 1,7742 \\
\hline & 10,60 & 6,30 & 1,6825 \\
\hline
\end{tabular}

- Relaçáo entre as alturas do pico do TA e do P.I 
Tabela 11 - Parâmetros analíticos obtidos para a elaboraça da curva padráo de calibraf̧a para a desonida (D) utilizando o acetato de dexametasona (ADM) como padráo interno (P.I).

\begin{tabular}{|c|c|c|c|}
\hline \multirow{2}{*}{$\begin{array}{c}\text { Concentração } \\
\text { (ng/mL) }\end{array}$} & \multicolumn{2}{|c|}{ Alturs do Pico $(\mathrm{cm})$} & \multirow{2}{*}{$\mathbf{R}^{*}$} \\
\hline & $\mathbf{D}$ & P.I & \\
\hline \multirow{3}{*}{25} & 0,60 & 6,10 & 0,0984 \\
\hline & 0,50 & 5,80 & 0,0862 \\
\hline & 0,60 & 6,00 & 0,1000 \\
\hline \multirow{3}{*}{50} & 1,50 & 7,50 & 0,2000 \\
\hline & 1,30 & 7,00 & 0,1857 \\
\hline & 1,20 & 6,20 & 0,1935 \\
\hline \multirow{3}{*}{100} & 3,00 & 7,70 & 0,3896 \\
\hline & 2,60 & 7,00 & 0,3714 \\
\hline & 2,50 & 6,70 & 0,3731 \\
\hline \multirow{3}{*}{200} & 5,80 & 7,00 & 0,8286 \\
\hline & 5,70 & 6,90 & 0,8261 \\
\hline & 5,20 & 6,80 & 0,7647 \\
\hline \multirow{3}{*}{400} & 12,30 & 7,00 & 1,7571 \\
\hline & 11,60 & 6,70 & 1,7313 \\
\hline & 10,8 & 6,50 & 1,6615 \\
\hline
\end{tabular}

- Relafáo entre as alturas do pico da D e do P.I. 


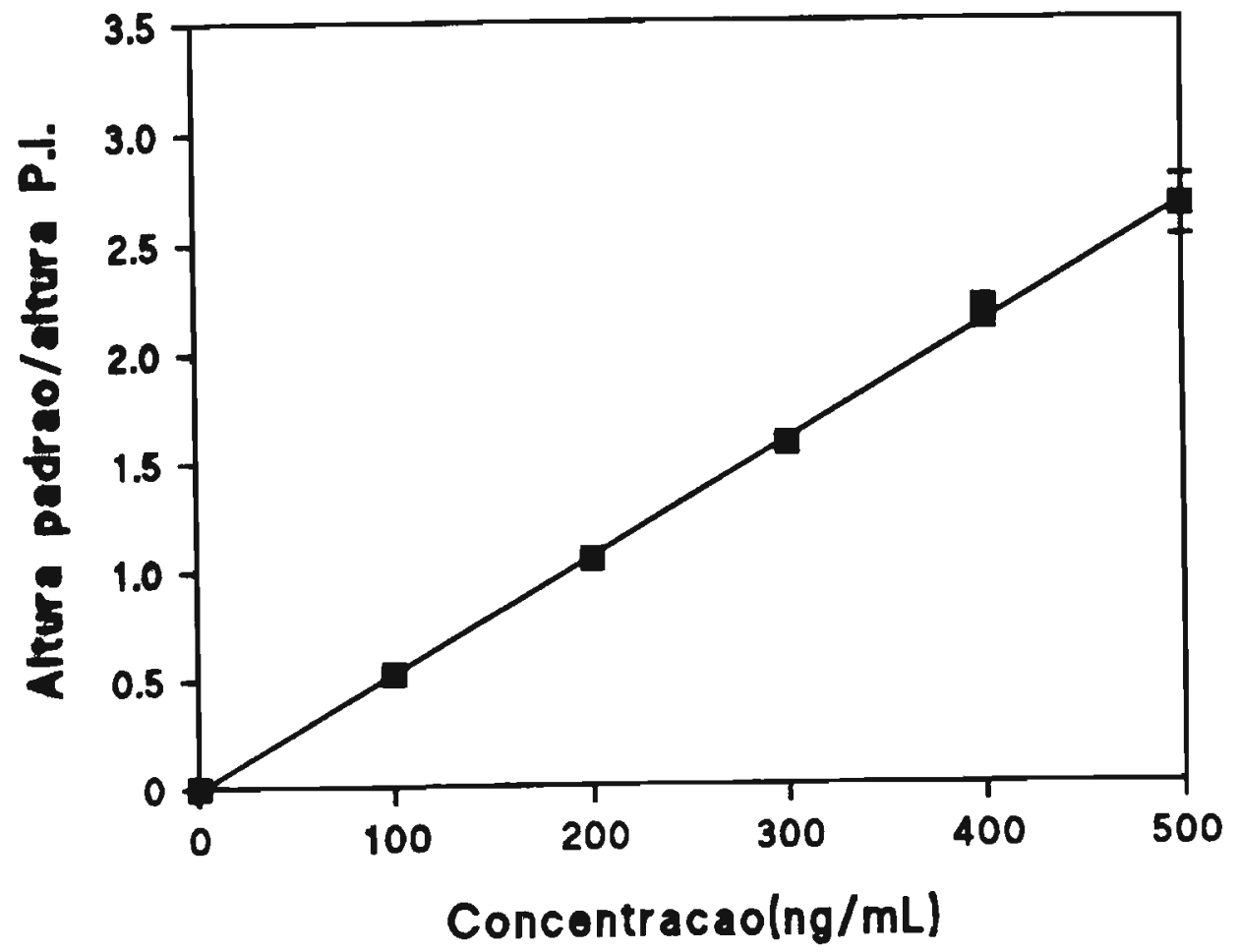

$$
\begin{aligned}
& y=0,005349 x-0,008925 \\
& r=0,9997
\end{aligned}
$$

Fgura 18 - Representafáo da curva de calibraço do acetato de hidrocortisona extraido da solução receptora adicionada. 


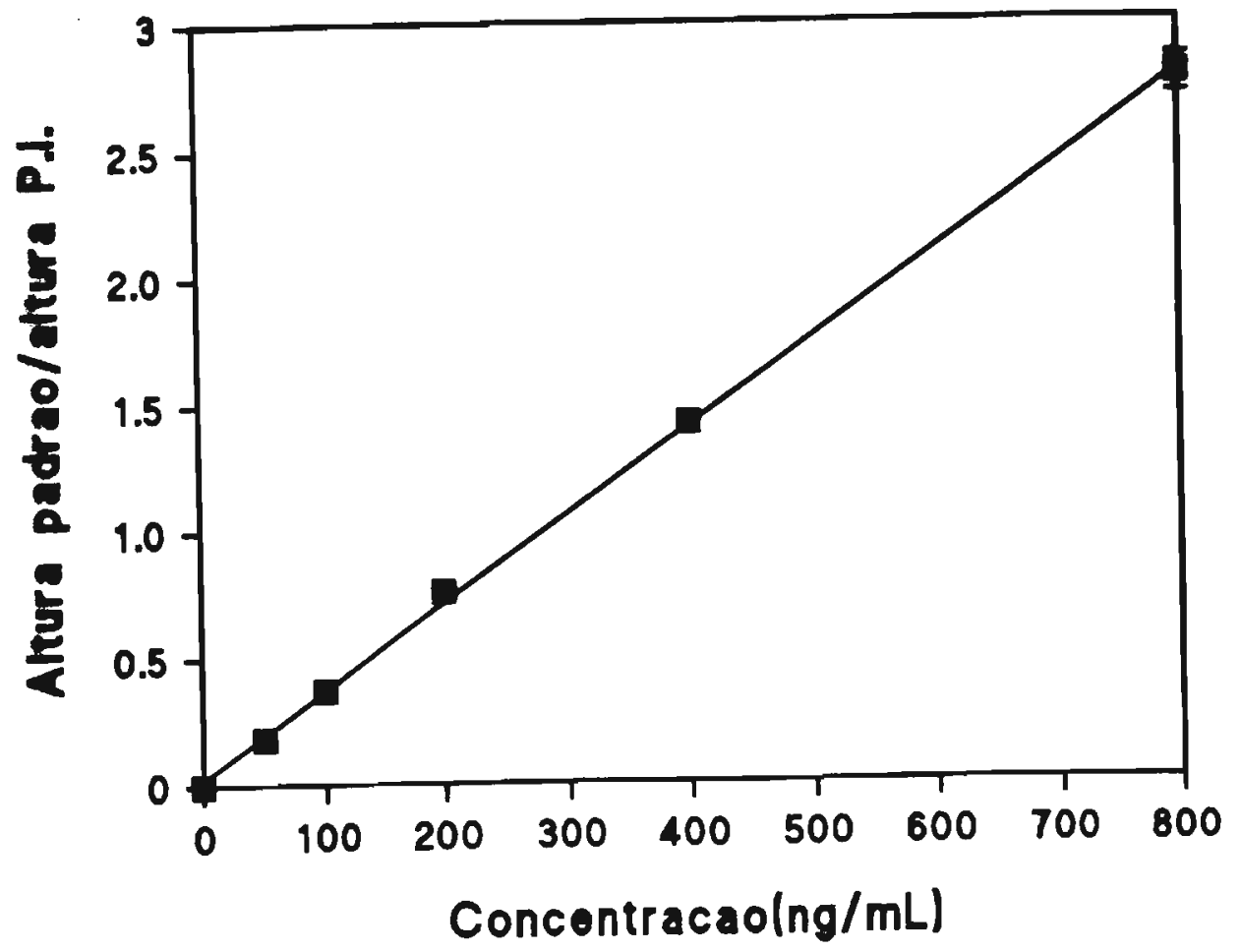

$$
\begin{aligned}
& y=0,003469 x+0,2222 \\
& r=0,9997
\end{aligned}
$$

Figura 19 - Representaça da curva de calibraça do acetato de dexametasona extraído da soluçáo receptora adicionada. 


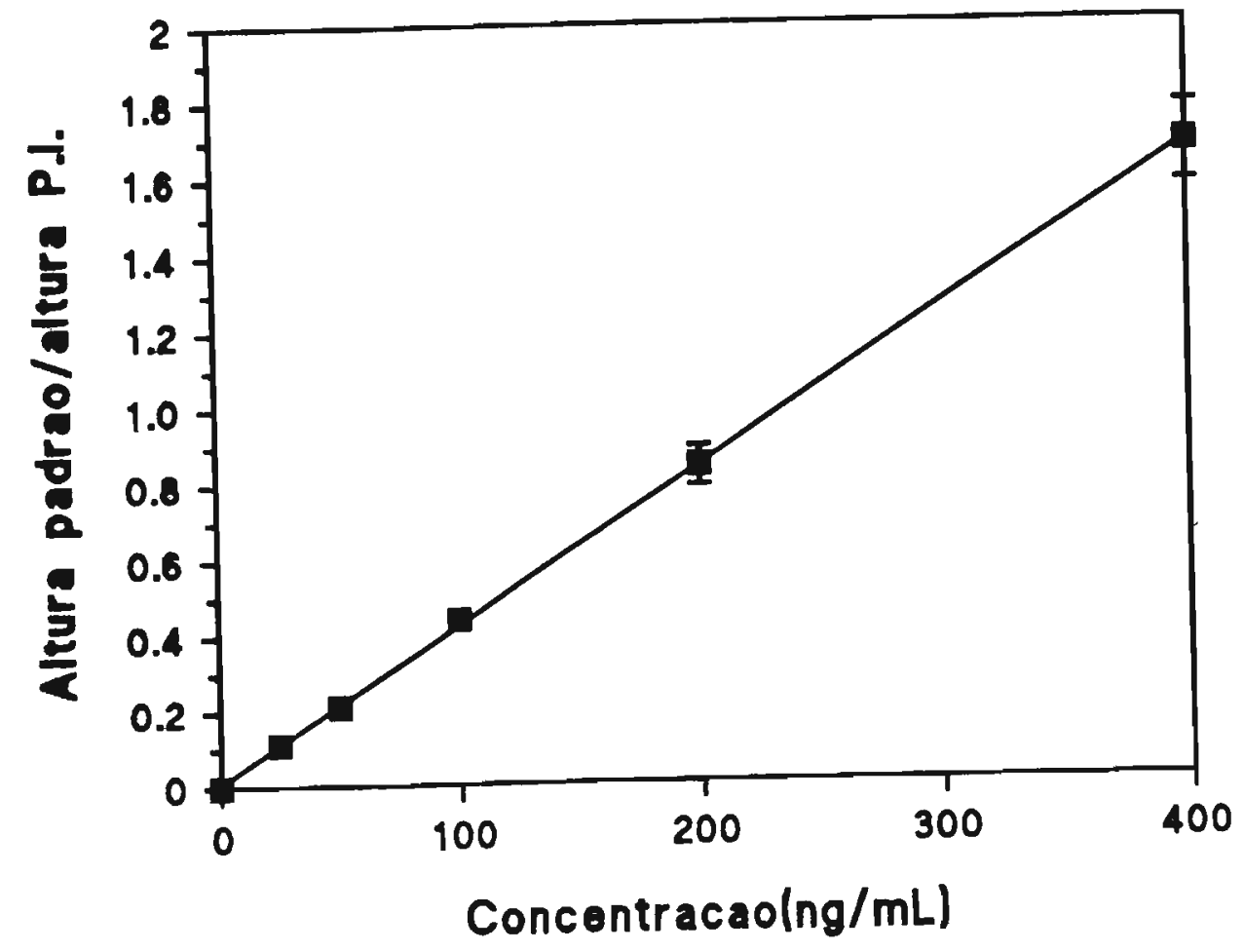

$y=0,04176 x-0,007733$

$r=0,9999$

Figura 20 - Representaçáo da curva de calibrafão da triamcinolona-acetonida extráda da soluçáo receptora adicionada. 


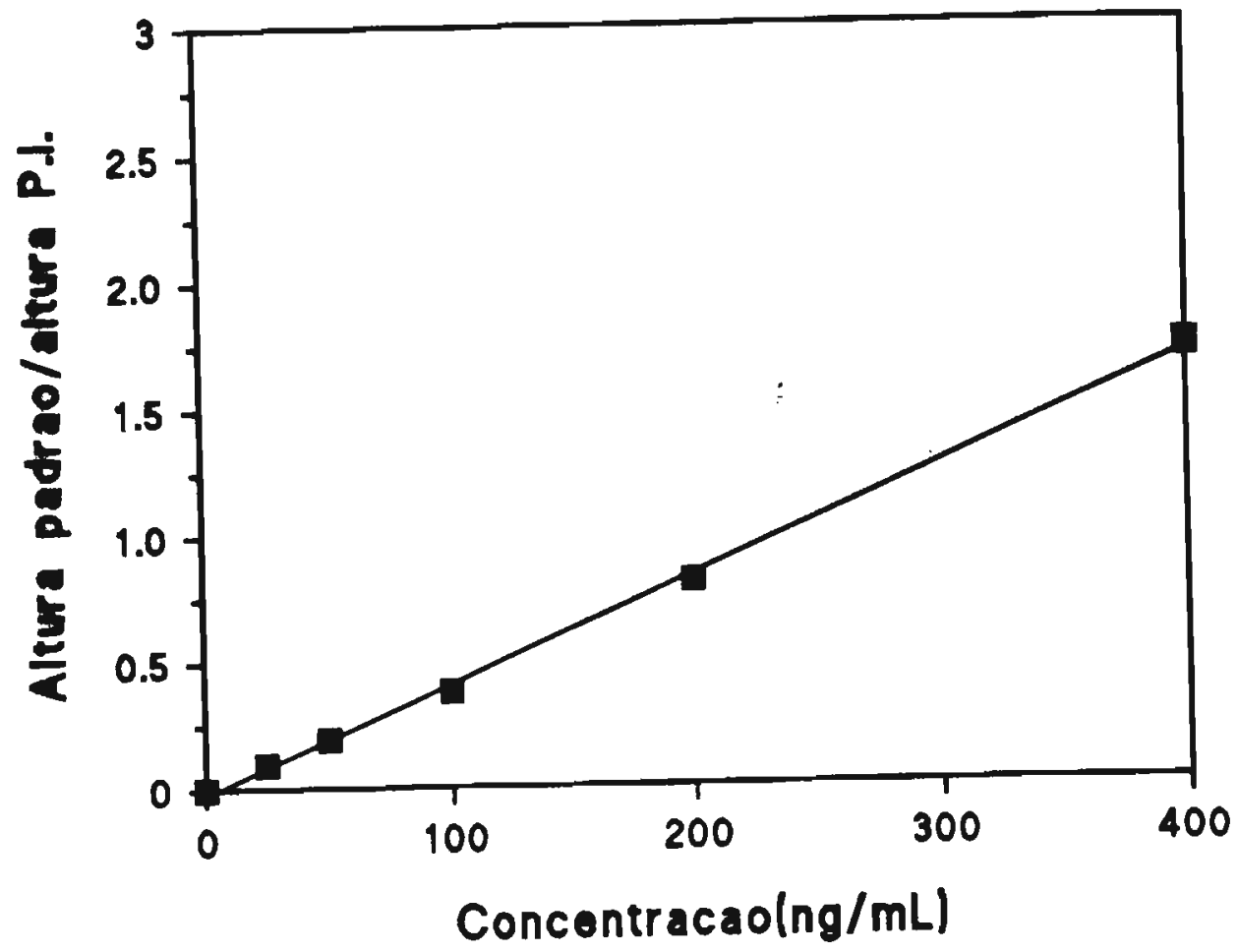

$$
\begin{aligned}
& y=0,004299 x-0,02375 \\
& r=0,9993
\end{aligned}
$$

Figura 21 - Representaçáo da curva de calibração da desonida extraida da soluçáo receptora adicionada 


\subsubsection{Veriflcação da eficlencia do processo de extração - Deteamtuação da Ro cuperação Relativa (Rr)}

Os resultados constantes na Tabela 12 mostram a recuperaf̧́⿴囗十 relativa (Rr) obtidas para os corticosteróides estudados conforme proposto no item 4.2.3.4.

Tabela 12 - Dados referentes a verificaçáo da recuperafão relativa (Rr) dos corticosteroides na solução receptora.

\begin{tabular}{|c|c|c|c|c|}
\hline \multirow{2}{*}{\multicolumn{2}{|c|}{ Corticosterdide }} & \multicolumn{2}{|c|}{$\begin{array}{l}\text { Relaçlo da Altura dos Picos do padráo e do padrio } \\
\text { interno }\end{array}$} & \multirow{2}{*}{$\operatorname{Rr}(\%)$} \\
\hline & & Nêo extraldo & Extraido & \\
\hline \multirow{3}{*}{ AHC } & 50 & $0,2600( \pm 0,010)$ & $0,2530( \pm 0,012)$ & 97,31 \\
\hline & 100 & $0,5500( \pm 0,015)$ & $0,5210( \pm 0,010)$ & 94,73 \\
\hline & 200 & $1,3500( \pm 0,076)$ & $1,2113( \pm 0,046)$ & 89,86 \\
\hline \multirow{3}{*}{$A D M$} & 50 & $0,2014( \pm 0,015)$ & $0,1830( \pm 0,017)$ & 90,86 \\
\hline & 100 & $0,3994( \pm 0,012)$ & $0,3556( \pm 0,015)$ & 89,03 \\
\hline & 200 & $0,8017( \pm 0,015)$ & $0,7701( \pm 0,060)$ & 96,06 \\
\hline \multirow{3}{*}{ TA } & 50 & $0,2230( \pm 0,015)$ & $0,2157( \pm 0,012)$ & 96,73 \\
\hline & 100 & $0,4960( \pm 0,015)$ & $0,4390( \pm 0,012)$ & 92,54 \\
\hline & 200 & $1,1049( \pm 0,046)$ & $0,9813( \pm 0,069)$ & $\infty 0,01$ \\
\hline \multirow{4}{*}{ D } & 50 & & & 92,86 \\
\hline & 100 & $0.2142(10,010)$ & $0,1270(10,016)$ & 94,22 \\
\hline & 200 & $0,4097( \pm 0,025)$ & $0,3896( \pm 0,012)$ & 95,58 \\
\hline & & $0,8513( \pm 0,030)$ & $0,8137( \pm 0,056)$ & \\
\hline
\end{tabular}

- Os valores em parênteses representam os desvios padráo referentes a trés determinaçoes. 


\subsubsection{Determinação por CLAE da quantidade de corticosteróldes nas formula- çôes de gel hidrófilos desenvolvidas}

A Tabela 13 mostra as quantidades de corticosteróides encontradas nas várias formulaçбes manipuladas apos execuçăo do item 4.2.3.5., seguido de determinaçáo por CLAE.

Tabela 13 - Quantidade de corticosterbide presentes nas formulą̧øes desenvolvidas, determinadas por CLAE.

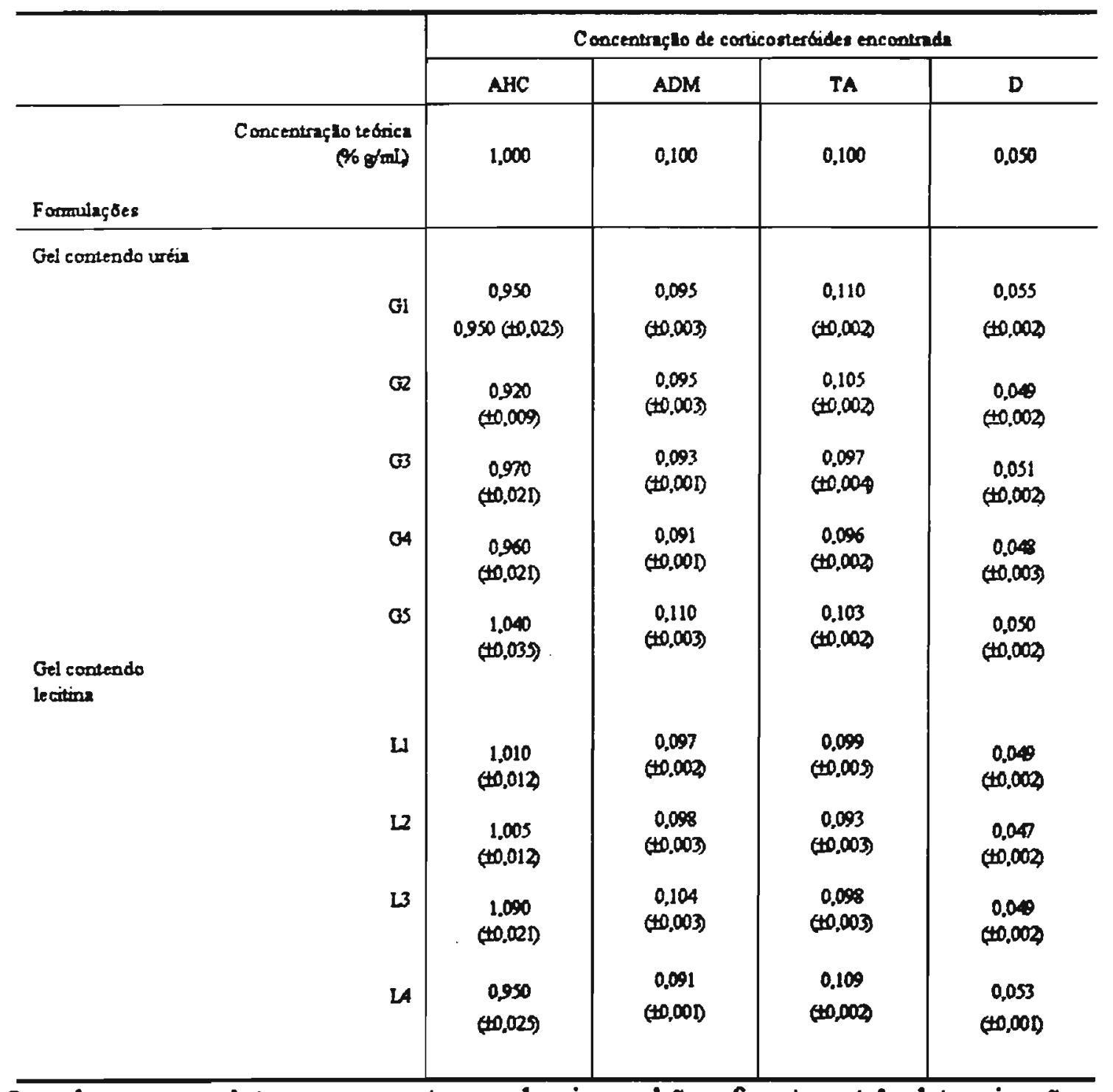

Os valores em pare̊nteses representam os desvios padråo referentes a tres determinaçes. 


\subsection{DETERMINAÇÃo DO COEFICIENTE DE PARTIÇÃo ÓLEO/AGUA DOS CORTICOSTERÓIDS EMPREGADOS NAS FORMULAÇÓES}

Na Tabela 14 estâo descritos os valores de coeficente de partiçấ óleo/água para os corticosterbides empregados, conforme metodologia descrita no item 4.2.4.

Tabela 14 - Coeficiente de partiçăo óleo/água dos corticosteróides.

\begin{tabular}{c|c}
\hline Corticosteróides & Coeficiente de partiçă O/A \\
\hline Acetado de hidrocortisons & $14,96 \quad( \pm 0,952)$ \\
Acetato de dexametasona & $31,92 \quad( \pm 0,919)$ \\
Desonida & $6,73 \quad( \pm 0,187)$ \\
Triamcinolona-acetonida & $12,50 \quad( \pm 0,503)$ \\
\hline
\end{tabular}

Os valores em pare̊nteses representam os desvios pardåo referentes a três determinaçชes. 


\subsection{EXPERIMENTOS DE LIBERAÇÃO E PENETRAÇÃO TRANCUTÃNEA IN VITRO, UTILIZANDO A CÉLULA DE DIFUSÃO No 3}

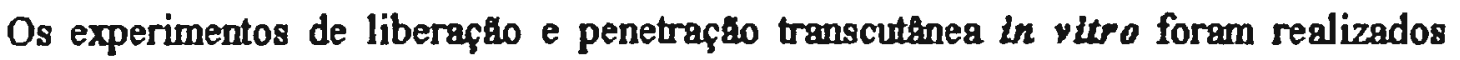
conforme descrito no item 4.2.5. Os resultados obtidos referentes à cinética da liberafáo dos corticosteróides AHC, ADM, D e TA contidos nas formulaçoes de géis contendo uréia $\left(G_{1}, G_{2}, G_{3}\right.$. $\mathrm{G}_{4}$ e $\left.\mathrm{G}_{5}\right)$ é géis contendo lecitina $\left(\mathrm{L}_{1}, \mathrm{~L}_{2}, \mathrm{~L}_{3}\right.$ e $\left.\mathrm{L}_{4}\right)$ encontram-se relacionados nas Tabelas 15, 16,17 e 18.

As Tabelas 19, 20, 21 e 22 indicam os dados de penetraçăo transcutánea referentes as mesmas formulafóes acima citadas. 
Tabela 15 - Valores de liberaçâ in vitro do AHC $\left(\mu \mathrm{g} / \mathrm{cm}^{2}\right)$ das formulaços de gel hidrofilo contendo uréia ou lecitina.

\begin{tabular}{|c|c|c|c|c|c|c|c|c|c|}
\hline & & \multicolumn{8}{|c|}{ AHC Eornl (Vz/Con) } \\
\hline \multicolumn{2}{|c|}{ Tempo (his } & 0 & 2 & 4 & 6 & 8 & 10 & 12 & 24 \\
\hline \multirow{5}{*}{$\begin{array}{c}\text { Gel } \\
\text { contendo } \\
\text { Urtix }\end{array}$} & $G_{2}$ & zero & $\begin{array}{l}15,163 \\
15,875 \\
16,075 \\
14,183 \\
\end{array}$ & $\begin{array}{l}17,234 \\
18,751 \\
16.131 \\
17,795\end{array}$ & $\begin{array}{l}20.143 \\
21.954 \\
22.035 \\
19.037\end{array}$ & $\begin{array}{l}27,437 \\
29,034 \\
26,181 \\
26,954\end{array}$ & $\begin{array}{l}40,147 \\
39,714 \\
36,162 \\
36,306\end{array}$ & $\begin{array}{l}51,400 \\
50,194 \\
50,935 \\
52,075\end{array}$ & $\begin{array}{l}61,143 \\
62,135 \\
59,995 \\
64201\end{array}$ \\
\hline & $G_{2}$ & zero & $\begin{array}{r}10,134 \\
9,875 \\
9,304 \\
11,071 \\
\end{array}$ & $\begin{array}{l}13,453 \\
12,957 \\
12,034 \\
14,035\end{array}$ & $\begin{array}{l}17,475 \\
18,081 \\
16,995 \\
17,034\end{array}$ & $\begin{array}{l}21,298 \\
22,345 \\
21,120 \\
20,034\end{array}$ & $\begin{array}{l}32,10 \\
35,037 \\
33,401 \\
31,179\end{array}$ & $\begin{array}{l}45,492 \\
43,784 \\
43,179 \\
4,971\end{array}$ & $\begin{array}{l}50,104 \\
51,179 \\
53,471 \\
5494\end{array}$ \\
\hline & $G$ & zero & $\begin{array}{l}7,594 \\
7,239 \\
6,995 \\
7,034 \\
\end{array}$ & $\begin{array}{l}11,342 \\
10,914 \\
10,031 \\
10,714 \\
\end{array}$ & $\begin{array}{l}15,071 \\
16,095 \\
16,412 \\
14,954 \\
\end{array}$ & $\begin{array}{l}18,304 \\
17,194 \\
17,301 \\
17,914 \\
\end{array}$ & $\begin{array}{l}27,140 \\
25,995 \\
27,003 \\
26,340\end{array}$ & $\begin{array}{l}37,410 \\
35,194 \\
36,034 \\
36,995\end{array}$ & $\begin{array}{l}40,574 \\
4,034 \\
38,771 \\
39,034\end{array}$ \\
\hline & $\mathbf{G}$ & zero & $\begin{array}{l}4.341 \\
5.071 \\
4.788 \\
4.811\end{array}$ & $\begin{array}{l}7,147 \\
7,007 \\
6,814 \\
6,994\end{array}$ & $\begin{array}{l}11,331 \\
12,091 \\
11,557 \\
11,851\end{array}$ & $\begin{array}{l}15,713 \\
16,995 \\
16,003 \\
15,975\end{array}$ & $\begin{array}{l}20,171 \\
21,995 \\
18,714 \\
21,340\end{array}$ & $\begin{array}{l}31,471 \\
28,995 \\
58,781 \\
29,003\end{array}$ & $\begin{array}{l}35,183 \\
36,545 \\
38,441 \\
33,187\end{array}$ \\
\hline & Gs & zero & $\begin{array}{l}2,772 \\
3,058 \\
2995 \\
2,801\end{array}$ & $\begin{array}{l}5,318 \\
5.071 \\
4,953 \\
4,871\end{array}$ & $\begin{array}{l}8,571 \\
8,325 \\
7,831 \\
7,903\end{array}$ & $\begin{array}{l}13,171 \\
12,995 \\
11,345 \\
13,007\end{array}$ & $\begin{array}{l}15,557 \\
14,095 \\
14,339 \\
14,571\end{array}$ & $\begin{array}{l}22,552 \\
21,045 \\
20,665 \\
20,813\end{array}$ & $\begin{array}{l}25,154 \\
25,975 \\
23,715 \\
24,071\end{array}$ \\
\hline \multirow{4}{*}{$\begin{array}{c}\text { Gel } \\
\text { contendo } \\
\text { Lecitinn }\end{array}$} & $\mathbf{L}_{\mathbf{4}}$ & zero & $\begin{array}{l}26,712 \\
26,143 \\
27,052 \\
24,031\end{array}$ & $\begin{array}{l}28,179 \\
28,331 \\
30,142 \\
31,475\end{array}$ & $\begin{array}{l}42,752 \\
43,412 \\
45,332 \\
41,997\end{array}$ & $\begin{array}{l}62,314 \\
59,172 \\
58,123 \\
57,995\end{array}$ & $\begin{array}{l}95,147 \\
93,475 \\
88,415 \\
89,180\end{array}$ & $\begin{array}{l}123,421 \\
120,137 \\
119,452 \\
122,109\end{array}$ & $\begin{array}{l}151,180 \\
142,300 \\
14,181 \\
147,275\end{array}$ \\
\hline & L & zero & $\begin{array}{l}15,135 \\
16,095 \\
14,331 \\
14,74\end{array}$ & $\begin{array}{l}19,457 \\
18,331 \\
21,044 \\
19,003\end{array}$ & $\begin{array}{l}35,181 \\
37,339 \\
34,181 \\
32,991\end{array}$ & $\begin{array}{l}50,14 \\
46,991 \\
47,180 \\
48,399\end{array}$ & $\begin{array}{l}71,147 \\
72,714 \\
75,131 \\
75,007\end{array}$ & $\begin{array}{l}92,133 \\
89,132 \\
95,187 \\
93,301\end{array}$ & $\begin{array}{l}120,331 \\
109,945 \\
113,183 \\
110,525\end{array}$ \\
\hline & L & zero & $\begin{array}{l}8.452 \\
8331 \\
8,915 \\
7,995\end{array}$ & $\begin{array}{l}12,314 \\
11,995 \\
13,007 \\
12,971\end{array}$ & $\begin{array}{l}21,457 \\
22,331 \\
22,895 \\
20,997\end{array}$ & $\begin{array}{l}35,185 \\
33,19 \\
34,189 \\
35,071\end{array}$ & $\begin{array}{l}52,300 \\
\$ 8,355 \\
4,007 \\
4,175\end{array}$ & $\begin{array}{l}69,183 \\
75,092 \\
73,141 \\
70,813\end{array}$ & $\begin{array}{l}82,173 \\
80,431 \\
77,158 \\
78,031\end{array}$ \\
\hline & 4 & zero & zero & zoro & zero & $\begin{array}{l}2375 \\
2518 \\
2197 \\
2203\end{array}$ & $\begin{array}{l}5.972 \\
7.143 \\
7.213 \\
6.431\end{array}$ & $\begin{array}{l}16,314 \\
17,912 \\
17,031 \\
17,500\end{array}$ & $\begin{array}{l}25,172 \\
23,192 \\
23,938 \\
24,005\end{array}$ \\
\hline
\end{tabular}


Tabela 16 - Valores de liberafão in vitro do ADM $\left(\mu \mathrm{g} / \mathrm{cm}^{2}\right)$ das formulą̧øes de gel hictrófilo contendo ureia ou lecitina.

\begin{tabular}{|c|c|c|c|c|c|c|c|c|c|}
\hline & & \multicolumn{8}{|c|}{ ADM beard (haterar) } \\
\hline \multicolumn{2}{|c|}{ Tempo (his } & 0 & 2 & 4 & 6 & 8 & 10 & 12 & 24 \\
\hline \multirow{5}{*}{$\begin{array}{c}\text { Gel } \\
\text { contendo } \\
\text { Ureil }\end{array}$} & $G$ & zero & $\begin{array}{l}9.195 \\
9.772 \\
8.868 \\
9.358\end{array}$ & $\begin{array}{l}11,381 \\
11,256 \\
10,939 \\
10,609\end{array}$ & $\begin{array}{l}12,475 \\
12,746 \\
13.822 \\
13.458\end{array}$ & $\begin{array}{l}19,565 \\
20,138 \\
19,950 \\
19,318\end{array}$ & $\begin{array}{l}28,670 \\
20,291 \\
28,584 \\
20,558\end{array}$ & $\begin{array}{l}37.040 \\
35.485 \\
34,876 \\
36.727\end{array}$ & $\begin{array}{l}38,593 \\
38,075 \\
39,614 \\
37,299\end{array}$ \\
\hline & $O_{2}$ & zero & $\begin{array}{l}4,616 \\
3,025 \\
4527 \\
4,882\end{array}$ & $\begin{array}{l}5,361 \\
5,251 \\
5,063 \\
5,086\end{array}$ & $\begin{array}{l}6.648 \\
6.492 \\
6.762 \\
6.368\end{array}$ & $\begin{array}{l}7,739 \\
8,122 \\
7,525 \\
7,935\end{array}$ & $\begin{array}{l}9.378 \\
9,606 \\
9.120 \\
9315\end{array}$ & $\begin{array}{l}12,359 \\
13,706 \\
15,348 \\
14,654\end{array}$ & $\begin{array}{l}21,116 \\
21,500 \\
20,719 \\
21,206\end{array}$ \\
\hline & $\mathbf{G}$ & zero & $\begin{array}{l}2,039 \\
2,480 \\
2,264 \\
2,152\end{array}$ & $\begin{array}{l}2,821 \\
2,898 \\
3,047 \\
2,577\end{array}$ & $\begin{array}{l}4,000 \\
3,821 \\
3,664 \\
4,180\end{array}$ & $\begin{array}{l}6,142 \\
6,517 \\
6,393 \\
6,318\end{array}$ & $\begin{array}{l}7,924 \\
7,820 \\
8,172 \\
7,612\end{array}$ & $\begin{array}{r}9,531 \\
9,688 \\
10,373 \\
9,241\end{array}$ & $\begin{array}{l}11,06 \\
11,570 \\
11,221 \\
12,200\end{array}$ \\
\hline & $G_{4}$ & wero & $\begin{array}{l}1,503 \\
2,027 \\
1,765 \\
1,635\end{array}$ & $\begin{array}{l}2,280 \\
2,393 \\
2,233 \\
2,260\end{array}$ & $\begin{array}{l}3,086 \\
2,892 \\
2,854 \\
2,989\end{array}$ & $\begin{array}{l}3,981 \\
4,362 \\
4,714 \\
4,317\end{array}$ & $\begin{array}{l}6,400 \\
6,256 \\
6,182 \\
6,567\end{array}$ & $\begin{array}{l}7,822 \\
8,173 \\
8,371 \\
7,301\end{array}$ & $\begin{array}{l}10,970 \\
10,765 \\
10,858 \\
10,687\end{array}$ \\
\hline & $G_{s}$ & zeso & $\begin{array}{l}1.02 \\
1,292 \\
1,189 \\
1,128\end{array}$ & $\begin{array}{l}1.563 \\
1.494 \\
1.451 \\
1.366\end{array}$ & $\begin{array}{l}2.152 \\
2055 \\
2.127 \\
1.976\end{array}$ & $\begin{array}{l}3.708 \\
3.571 \\
3.332 \\
3.616\end{array}$ & $\begin{array}{l}5.264 \\
5,012 \\
5.684 \\
4954\end{array}$ & $\begin{array}{l}6.688 \\
6.556 \\
6.331 \\
6.754\end{array}$ & $\begin{array}{l}9.172 \\
89010 \\
8.818 \\
9.400\end{array}$ \\
\hline \multirow{4}{*}{$\begin{array}{c}\text { Gel } \\
\text { contendo } \\
\text { Lecitinn }\end{array}$} & L & zero & $\begin{array}{l}11,281 \\
10.659 \\
11.492 \\
11.107\end{array}$ & $\begin{array}{l}16,082 \\
16,506 \\
15,780 \\
16,043\end{array}$ & $\begin{array}{l}18,732 \\
18,622 \\
19,502 \\
19,080\end{array}$ & $\begin{array}{l}23,723 \\
23,581 \\
23,284 \\
23,575\end{array}$ & $\begin{array}{l}30,298 \\
31,182 \\
30,810 \\
32,627\end{array}$ & $\begin{array}{l}34,486 \\
35,595 \\
35,552 \\
34,739\end{array}$ & $\begin{array}{l}44,000 \\
2,090 \\
2600 \\
44,001\end{array}$ \\
\hline & $\mathbf{L}$ & zero & $\begin{array}{l}4456 \\
4356 \\
4154 \\
4041\end{array}$ & $\begin{array}{l}4,950 \\
4,938 \\
4,780 \\
5,336\end{array}$ & $\begin{array}{l}5,937 \\
6,188 \\
6,091 \\
6,228\end{array}$ & $\begin{array}{l}8,904 \\
9,057 \\
9,49 \\
9,241\end{array}$ & $\begin{array}{l}18,383 \\
18,744 \\
18,269 \\
18,632\end{array}$ & $\begin{array}{l}25,510 \\
26,182 \\
26,048 \\
26,333\end{array}$ & $\begin{array}{l}40,49 \\
4,262 \\
41,132 \\
41,968\end{array}$ \\
\hline & L & zero & $\begin{array}{l}3,211 \\
2979 \\
2711 \\
3,073\end{array}$ & $\begin{array}{l}3,659 \\
3,353 \\
3,740 \\
3,844\end{array}$ & $\begin{array}{l}4567 \\
4,604 \\
4580 \\
4,616\end{array}$ & $\begin{array}{l}7.063 \\
7.178 \\
7.488 \\
7.310\end{array}$ & $\begin{array}{l}9,4025 \\
9,4179 \\
9,2711 \\
9,020\end{array}$ & $\begin{array}{l}11,9042 \\
12,1766 \\
11,7699 \\
12,0286\end{array}$ & $\begin{array}{l}17,4751 \\
17,8100 \\
17,5710\end{array}$ \\
\hline & $\mathrm{L}$ & zero & zerso & vero & zero & zero & $\begin{array}{l}0.710 \\
0.920 \\
0.833 \\
0.616\end{array}$ & $\begin{array}{l}1,290 \\
1.555 \\
1,735 \\
1,437\end{array}$ & $\begin{array}{l}3,471 \\
3,553 \\
3,321 \\
3,698\end{array}$ \\
\hline
\end{tabular}


Tabela 17 - Valores de liberą̧⿰丿丶⿸⿴巳一丶 in vitro da D $\left(\mu \mathrm{g} / \mathrm{cm}^{2}\right)$ das formulaços de gel hidrófilo contendo uréia ou lecitina

\begin{tabular}{|c|c|c|c|c|c|c|c|c|c|}
\hline & & \multicolumn{8}{|c|}{ D Lernde (pelene) } \\
\hline \multicolumn{2}{|c|}{ Tempo ond } & 0 & 2 & 4 & 6 & 8 & 10 & 12 & 24 \\
\hline \multirow{5}{*}{$\begin{array}{c}\text { Gel } \\
\text { comendo } \\
\text { Urtin }\end{array}$} & $G$ & zero & $\begin{array}{l}12,274 \\
10,861 \\
11,095 \\
12,102\end{array}$ & $\begin{array}{l}35,507 \\
31,182 \\
30,833 \\
32,388\end{array}$ & $\begin{array}{l}33,775 \\
33,669 \\
31,169 \\
32,823\end{array}$ & $\begin{array}{l}34,981 \\
36,107 \\
37,624 \\
39,851\end{array}$ & $\begin{array}{l}61,634 \\
58,520 \\
60,560 \\
61,231\end{array}$ & $\begin{array}{l}83,200 \\
80,896 \\
79,005 \\
80,900\end{array}$ & $\begin{array}{r}94,569 \\
99,801 \\
93,321 \\
100,796\end{array}$ \\
\hline & $G$ & zero & $\begin{array}{l}6,480 \\
7,351 \\
7,143 \\
6,262\end{array}$ & $\begin{array}{l}12,203 \\
11,209 \\
12,193 \\
11,168\end{array}$ & $\begin{array}{l}25,761 \\
24,913 \\
23,730 \\
25,519\end{array}$ & $\begin{array}{l}27,117 \\
27,376 \\
25,685 \\
25,321\end{array}$ & $\begin{array}{l}27,117 \\
27,014 \\
26,883 \\
27,241\end{array}$ & $\begin{array}{l}30,062 \\
28,284 \\
28,675 \\
20,45\end{array}$ & $\begin{array}{l}51,800 \\
50,580 \\
51, \pi 0 \\
0,500\end{array}$ \\
\hline & $G$ & zero & $\begin{array}{l}13,882 \\
12,973 \\
12,736 \\
12,078\end{array}$ & $\begin{array}{l}15,602 \\
15,386 \\
14,923 \\
15215\end{array}$ & $\begin{array}{l}19,847 \\
19,988 \\
18,654 \\
19.638 \\
\end{array}$ & $\begin{array}{l}26,721 \\
26,750 \\
25,757 \\
26,206\end{array}$ & $\begin{array}{l}39,354 \\
39.287 \\
39,810 \\
39.165\end{array}$ & $\begin{array}{l}4.127 \\
47,313 \\
46,928 \\
47571\end{array}$ & $\begin{array}{l}58.300 \\
54.65 \\
56.20 \\
57.131\end{array}$ \\
\hline & $\mathrm{G}_{4}$ & zero & $\begin{array}{l}7,287 \\
7,002 \\
7,359 \\
6,642\end{array}$ & $\begin{array}{l}14,949 \\
16,281 \\
15,409 \\
15,863\end{array}$ & $\begin{array}{l}19,565 \\
20,883 \\
19.863 \\
19,950\end{array}$ & $\begin{array}{l}18948 \\
19.988 \\
18321 \\
17.898\end{array}$ & $\begin{array}{l}20,405 \\
21,878 \\
22,455 \\
22,550\end{array}$ & $\begin{array}{l}23,562 \\
24,067 \\
23,918 \\
23,305\end{array}$ & $\begin{array}{l}34,167 \\
35,338 \\
33,601 \\
32,735\end{array}$ \\
\hline & Gs & zeso & $\begin{array}{l}6,532 \\
7,189 \\
6,704 \\
6,928\end{array}$ & $\begin{array}{l}7,403 \\
7,866 \\
7,571 \\
7,838\end{array}$ & $\begin{array}{l}8,739 \\
9,369 \\
9,129 \\
8,942\end{array}$ & $\begin{array}{l}13,109 \\
12,922 \\
12,140 \\
12,603\end{array}$ & $\begin{array}{l}14,975 \\
13,658 \\
13,902 \\
14,216\end{array}$ & $\begin{array}{l}15,025 \\
15,112 \\
17,090 \\
15,622\end{array}$ & $\begin{array}{l}19,988 \\
22,562 \\
22,086 \\
21,034\end{array}$ \\
\hline \multirow{4}{*}{$\begin{array}{c}\text { Gel } \\
\text { contendo } \\
\text { Lecitin }\end{array}$} & 4 & zero & $\begin{array}{l}10,6629 \\
10,5659 \\
10,5808 \\
10,6356\end{array}$ & $\begin{array}{l}14,9627 \\
14,8134 \\
15,217 \\
15,0460\end{array}$ & $\begin{array}{l}23,3085 \\
23,5485 \\
23,1990 \\
23,6381\end{array}$ & $\begin{array}{l}33,8147 \\
34,8400 \\
34,2251 \\
34,5896\end{array}$ & $\begin{array}{l}40,3905 \\
50,2069 \\
50,3943 \\
48,5162\end{array}$ & $\begin{array}{l}63,5211 \\
56,0087 \\
55,3706 \\
51,0361\end{array}$ & $\begin{array}{l}76,6313 \\
7,7881 \\
81,7501 \\
80,263\end{array}$ \\
\hline & L. & zero & $\begin{array}{l}8,1020 \\
7,9254 \\
7,9913 \\
8,2102\end{array}$ & $\begin{array}{r}9,8483 \\
10,0920 \\
10,4714 \\
9,8346 \\
\end{array}$ & $\begin{array}{l}11,3358 \\
12,4664 \\
12,0784 \\
11,8448\end{array}$ & $\begin{array}{l}21,4003 \\
18,9465 \\
22,4104 \\
20,5410\end{array}$ & $\begin{array}{l}36,9577 \\
32,9823 \\
35,7376 \\
35,2201\end{array}$ & $\begin{array}{l}53,5025 \\
56,0087 \\
55,3706 \\
51,0361\end{array}$ & $\begin{array}{l}65,3184 \\
70,7923 \\
62,2264 \\
67,8085\end{array}$ \\
\hline & L & zero & $\begin{array}{l}3.4104 \\
3.4826 \\
3.6107 \\
3,2711\end{array}$ & $\begin{array}{l}43731 \\
41294 \\
4,6206 \\
4,5908\end{array}$ & $\begin{array}{l}6,5199 \\
6,2587 \\
6,8644 \\
6,6107\end{array}$ & $\begin{array}{l}11,9055 \\
12,8607 \\
12,0871 \\
12,3538\end{array}$ & $\begin{array}{l}22,0647 \\
23,0286 \\
22,7786 \\
22,4254\end{array}$ & $\begin{array}{l}31,1940 \\
322301 \\
32,5124 \\
31,9838\end{array}$ & $\begin{array}{l}40,2306 \\
41.1915 \\
36,719 \\
39,8184\end{array}$ \\
\hline & 4 & zero & zeto & zero & $\begin{array}{l}0,7226 \\
0,6741 \\
0,7550 \\
0,7587\end{array}$ & $\begin{array}{l}1,6381 \\
1,7550 \\
1,6107 \\
1,7065\end{array}$ & $\begin{array}{l}3,1318 \\
29963 \\
3,1130 \\
3,0071\end{array}$ & $\begin{array}{l}4,0968 \\
5,0052 \\
47463 \\
4,8333\end{array}$ & $\begin{array}{l}7,024 \\
8,300 \\
8,100 \\
7,5090\end{array}$ \\
\hline
\end{tabular}


Tabela 18 - Valores de liberação in vitro da TA $\left(\mu g / \mathrm{cm}^{2}\right)$ das formulaçðes de gel hidrofilo contendo uréia ou lecitina.

\begin{tabular}{|c|c|c|c|c|c|c|c|c|c|}
\hline & & \multicolumn{8}{|c|}{ TA Berab (1) Jant) } \\
\hline \multicolumn{2}{|c|}{ Tempo (h) } & 0 & 2 & 4 & 6 & 8 & 10 & 12 & 24 \\
\hline \multirow{5}{*}{$\begin{array}{c}\text { Gel } \\
\text { contendo } \\
\text { Urtia }\end{array}$} & $G_{1}$ & $z e s 0$ & $\begin{array}{l}8.959 \\
8.624 \\
8.572 \\
8.881\end{array}$ & $\begin{array}{l}10,863 \\
10,759 \\
10,883 \\
10,34\end{array}$ & $\begin{array}{l}11,863 \\
12,617 \\
13,684 \\
11,381\end{array}$ & $\begin{array}{l}13.718 \\
13594 \\
14357 \\
12376\end{array}$ & $\begin{array}{l}26,920 \\
26,776 \\
24,805 \\
24,50\end{array}$ & $\begin{array}{l}28,881 \\
29,403 \\
27,786 \\
20,516\end{array}$ & $\begin{array}{l}36,990 \\
34906 \\
33,507 \\
37,623\end{array}$ \\
\hline & $\mathbf{G}_{\mathbf{2}}$ & zero & $\begin{array}{r}10,647 \\
10,364 \\
9,879 \\
10,000\end{array}$ & $\begin{array}{l}11,759 \\
11,256 \\
11,978 \\
11,128\end{array}$ & $\begin{array}{l}15,364 \\
16,107 \\
14,862 \\
16,405\end{array}$ & $\begin{array}{l}24,388 \\
23,304 \\
23,546 \\
24,055\end{array}$ & $\begin{array}{l}26,754 \\
26,157 \\
26,001 \\
26,868\end{array}$ & $\begin{array}{l}31,118 \\
31,990 \\
30,236 \\
32,209\end{array}$ & $\begin{array}{l}44,739 \\
45,199 \\
43,400 \\
39,839\end{array}$ \\
\hline & $G_{3}$ & $z e 50$ & $\begin{array}{l}21,519 \\
19,503 \\
19,565 \\
20,548\end{array}$ & $\begin{array}{l}37,009 \\
35,000 \\
34,764 \\
36,231\end{array}$ & $\begin{array}{l}46,094 \\
45,123 \\
44,826 \\
46,256\end{array}$ & $\begin{array}{l}4,221 \\
4,788 \\
47,438 \\
48,445\end{array}$ & $\begin{array}{l}41,41 \\
43,619 \\
45,958 \\
42,016\end{array}$ & $\begin{array}{l}50,065 \\
51,020 \\
51,654 \\
4,782\end{array}$ & $\begin{array}{l}56,061 \\
54,652 \\
55,659 \\
56,368\end{array}$ \\
\hline & $\mathbf{G}_{4}$ & zeso & $\begin{array}{l}4.801 \\
4.40 \\
4627 \\
4.853\end{array}$ & $\begin{array}{l}5.621 \\
5.688 \\
5,373 \\
5.536\end{array}$ & $\begin{array}{l}7.164 \\
7.026 \\
7.102 \\
6.368\end{array}$ & $\begin{array}{l}9,914 \\
9,953 \\
9.418 \\
9,571\end{array}$ & $\begin{array}{l}10,631 \\
10,361 \\
10,872 \\
10,450\end{array}$ & $\begin{array}{l}12,415 \\
12,475 \\
13,594 \\
12,114\end{array}$ & $\begin{array}{l}26.206 \\
27.05 \\
27.152 \\
30.262\end{array}$ \\
\hline & Gs & zero & $\begin{array}{l}3,043 \\
3,184 \\
2,973 \\
2,655\end{array}$ & $\begin{array}{l}4,461 \\
4,154 \\
4,481 \\
3,694\end{array}$ & $\begin{array}{l}6.046 \\
5,410 \\
5.249 \\
5.282\end{array}$ & $\begin{array}{r}8,098 \\
7,848 \\
8,6119 \\
7,754\end{array}$ & $\begin{array}{r}9,430 \\
10,099 \\
9,876 \\
10,970\end{array}$ & $\begin{array}{l}13,132 \\
13,831 \\
12,848 \\
12,551\end{array}$ & $\begin{array}{l}18,075 \\
18,666 \\
21,070 \\
19,092\end{array}$ \\
\hline \multirow{4}{*}{$\begin{array}{c}\text { Gel } \\
\text { contendo } \\
\text { Lecitinx }\end{array}$} & $L_{1}$ & zero & $\begin{array}{l}7,1915 \\
7,0050 \\
7,0945 \\
7,2201\end{array}$ & $\begin{array}{l}8,1343 \\
7,3756 \\
7,4079 \\
7,9353\end{array}$ & $\begin{array}{r}10,3794 \\
10,1119 \\
10,6119 \\
9,8010\end{array}$ & $\begin{array}{l}11,5796 \\
12,4490 \\
12,1144 \\
12,2015\end{array}$ & $\begin{array}{l}23,1841 \\
24,1045 \\
23,4204 \\
23,5323\end{array}$ & $\begin{array}{l}27,0274 \\
27,3881 \\
26,7662 \\
23,7960\end{array}$ & $\begin{array}{l}38,2463 \\
40,4726 \\
4,8124 \\
41,5877\end{array}$ \\
\hline & 4 & 2020 & $\begin{array}{l}4,1692 \\
4,0299 \\
3,8210 \\
3,5970\end{array}$ & $\begin{array}{l}5,9577 \\
6,0075 \\
5,6978 \\
5,6741\end{array}$ & $\begin{array}{l}8,1866 \\
8,2127 \\
7,7637 \\
7,8756\end{array}$ & $\begin{array}{l}10,7587 \\
11,1716 \\
10,6120 \\
10,9080\end{array}$ & $\begin{array}{l}17,8856 \\
18,6965 \\
17,3383 \\
17,019\end{array}$ & $\begin{array}{l}23,2960 \\
23,7338 \\
23,4950 \\
25,2985\end{array}$ & $\begin{array}{l}31,4192 \\
329975 \\
31,0784 \\
32,403\end{array}$ \\
\hline & Ls & zero & $\begin{array}{l}2,7139 \\
2,4005 \\
2,5908 \\
23085\end{array}$ & $\begin{array}{l}45096 \\
4305 \\
41567 \\
41692\end{array}$ & $\begin{array}{l}6,5684 \\
7,1891 \\
6,6231 \\
6,9450\end{array}$ & $\begin{array}{l}9,3806 \\
9,4776 \\
8,7624 \\
8,9330\end{array}$ & $\begin{array}{l}12,7114 \\
13,5958 \\
121667 \\
123259\end{array}$ & $\begin{array}{l}19,6167 \\
16,8408 \\
17.7612 \\
17.7990\end{array}$ & $\begin{array}{l}26,1356 \\
28,7065 \\
23,5560 \\
24520\end{array}$ \\
\hline & 4 & zero & zero & wero & zero & $\begin{array}{l}4552 \\
41692 \\
4574 \\
42048\end{array}$ & $\begin{array}{l}5,0124 \\
49527 \\
4,6503 \\
5,1244\end{array}$ & $\begin{array}{l}8,8085 \\
8,3731 \\
8,1368 \\
8,9204\end{array}$ & $\begin{array}{l}11,2650 \\
13,700 \\
13,300 \\
12,100\end{array}$ \\
\hline
\end{tabular}


Tabela 19 - Valores de penetraça transcutanea in vitro do $\mathrm{AHC}\left(\mu \mathrm{g} / \mathrm{cm}^{2}\right)$ das formulaçes de gel hidrofilo contendo uréia ou lecitina

\begin{tabular}{|c|c|c|c|c|c|c|c|c|c|}
\hline & & \multicolumn{8}{|c|}{ AHC powtrode (He/cor) } \\
\hline \multicolumn{2}{|c|}{ Tenpo ond } & $0:$ & 2 & 4 & 6 & 8 & 10 & 12 & 24 \\
\hline \multirow{5}{*}{$\begin{array}{c}\text { Gel } \\
\text { contendo } \\
\text { Urtix }\end{array}$} & $\mathbf{G}_{\mathbf{2}}$ & zero & $\begin{array}{r}5,792 \\
5,237 \\
5,397 \\
5,531\end{array}$ & $\begin{array}{l}6,010 \\
6,050 \\
5,997 \\
5,831\end{array}$ & $\begin{array}{l}6.417 \\
6.321 \\
6.872 \\
6,531\end{array}$ & $\begin{array}{l}8,123 \\
8,791 \\
8,621 \\
8,597\end{array}$ & $\begin{array}{l}11,371 \\
12,432 \\
12,031 \\
10,991\end{array}$ & $\begin{array}{l}15,471 \\
16,091 \\
15,031 \\
14,995\end{array}$ & $\begin{array}{l}19,183 \\
20,991 \\
21,321 \\
20,753\end{array}$ \\
\hline & $a_{2}$ & 2050 & $\begin{array}{l}6.034 \\
6,312 \\
6,217 \\
6.431\end{array}$ & $\begin{array}{l}6,530 \\
6,071 \\
6,392 \\
6,643\end{array}$ & $\begin{array}{l}8.372 \\
8.457 \\
8.061 \\
8.210\end{array}$ & $\begin{array}{r}10,134 \\
10,055 \\
9.713 \\
9.804\end{array}$ & $\begin{array}{l}13957 \\
13.853 \\
1270 \\
12901\end{array}$ & $\begin{array}{l}18,034 \\
17,563 \\
17,930 \\
17,304\end{array}$ & $\begin{array}{l}25,147 \\
23,131 \\
24,031 \\
24,379\end{array}$ \\
\hline & $\mathbf{G}_{3}$ & zero & zero & zero & $\begin{array}{l}3,071 \\
3,140 \\
3,297 \\
3,185\end{array}$ & $\begin{array}{l}4397 \\
4703 \\
4681 \\
4551\end{array}$ & $\begin{array}{l}6,133 \\
6,271 \\
5,831 \\
5,905\end{array}$ & $\begin{array}{l}9,337 \\
9,005 \\
9,582 \\
9,871\end{array}$ & $\begin{array}{r}13,156 \\
132,121 \\
12,991 \\
14,71\end{array}$ \\
\hline & $\mathbf{G}_{4}$ & zero & zero & $2 e r 0$ & zero & zero & zero & zero & zero \\
\hline & $G_{3}$ & zero & zero & zero & zero & zero & zero & zero & $\begin{array}{l}5,40 \\
6,01 \\
4,97 \\
4,83\end{array}$ \\
\hline \multirow{4}{*}{$\begin{array}{c}\text { Ged } \\
\text { contendo } \\
\text { Lecitina }\end{array}$} & 4 & zero & $\begin{array}{l}6,304 \\
6,907 \\
5,805 \\
5,917\end{array}$ & $\begin{array}{l}7,954 \\
7,531 \\
8,382 \\
7,705\end{array}$ & $\begin{array}{r}9.1332 \\
10,055 \\
10,000 \\
9,572\end{array}$ & $\begin{array}{l}12331 \\
11,897 \\
13,071 \\
12,005\end{array}$ & $\begin{array}{l}16,331 \\
17,856 \\
15,905 \\
17,037\end{array}$ & $\begin{array}{l}23,071 \\
21,895 \\
22,331 \\
23,005\end{array}$ & $\begin{array}{l}26.711 \\
25.180 \\
27.14 \\
24.995\end{array}$ \\
\hline & 4 & zero & $\begin{array}{l}4,352 \\
3,995 \\
4213 \\
4,195\end{array}$ & $\begin{array}{l}5,997 \\
6,034 \\
6,317 \\
6,091\end{array}$ & $\begin{array}{l}8,071 \\
7,321 \\
7,504 \\
7,771\end{array}$ & $\begin{array}{r}10,992 \\
11,034 \\
9,971 \\
10,351\end{array}$ & $\begin{array}{l}14,995 \\
13,303 \\
13,517 \\
13,701\end{array}$ & $\begin{array}{l}20,19 \\
19,354 \\
18,991 \\
19,600\end{array}$ & $\begin{array}{r}23,451 \\
23,003 \\
21,965222,901\end{array}$ \\
\hline & $\mathbf{L}_{\mathbf{s}}$ & zero & zero & zero & zero & zero & sero & zero & $\begin{array}{l}3,205 \\
3,452 \\
3,139 \\
3,507\end{array}$ \\
\hline & 4 & zeso & 2000 & zero & $=00$ & 2000 & 2000 & 2000 & $\begin{array}{l}2,321 \\
2,507 \\
2,301 \\
2,407\end{array}$ \\
\hline
\end{tabular}


Tabela 20 - Valores de penetraçáo transcutanea in vitro do ADM $\left(\mu g / \mathrm{cm}^{2}\right)$ das formulaf̧es de gel hidrófilo contendo uréia ou lecitina

\begin{tabular}{|c|c|c|c|c|c|c|c|c|c|}
\hline & & \multicolumn{8}{|c|}{ 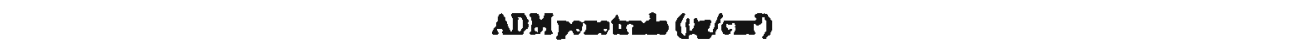 } \\
\hline \multicolumn{2}{|c|}{ Tempo (hil } & 0 & 2 & 4 & 6 & 8 & 10 & 12 & 24 \\
\hline \multirow{5}{*}{$\begin{array}{c}\text { Gel } \\
\text { contendo } \\
\text { Urtix }\end{array}$} & $G_{2}$ & zero & $\begin{array}{l}1,287 \\
1,225 \\
1,381 \\
1,208\end{array}$ & $\begin{array}{l}1,654 \\
1,611 \\
1,679 \\
1,766\end{array}$ & $\begin{array}{l}2,297 \\
2,402 \\
2,24 \\
2,232\end{array}$ & $\begin{array}{l}2,831 \\
2,730 \\
2,74 \\
2,867\end{array}$ & $\begin{array}{l}3,147 \\
3,246 \\
3,215 \\
3,097\end{array}$ & $\begin{array}{l}3,701 \\
3,738 \\
3,632 \\
3,601\end{array}$ & $\begin{array}{l}4,675 \\
4,801 \\
4,979 \\
4708\end{array}$ \\
\hline & $\mathbf{G}_{\mathbf{3}}$ & zero & $\begin{array}{l}1,580 \\
1.430 \\
1,623 \\
1.486\end{array}$ & $\begin{array}{l}1,965 \\
1,859 \\
1,903 \\
1,892\end{array}$ & $\begin{array}{l}2,121 \\
2,096 \\
2,108 \\
2,182\end{array}$ & $\begin{array}{l}2,539 \\
2,481 \\
2,400 \\
2,575\end{array}$ & $\begin{array}{l}2,930 \\
2,807 \\
2,798 \\
3,073\end{array}$ & $\begin{array}{l}3,384 \\
3,333 \\
3,400 \\
3,272\end{array}$ & $\begin{array}{l}4205 \\
4,042 \\
4306 \\
4362\end{array}$ \\
\hline & $G_{3}$ & zero & zero & zero & $\begin{array}{l}0.946 \\
0.979 \\
0.995 \\
1.001\end{array}$ & $\begin{array}{l}1.499 \\
1.400 \\
1.357 \\
1.405\end{array}$ & $\begin{array}{l}2,007 \\
1,990 \\
1,903 \\
1,805\end{array}$ & $\begin{array}{l}2.593 \\
2,476 \\
2,531 \\
2,313\end{array}$ & $\begin{array}{l}3,553 \\
3,695 \\
3,806 \\
3,918\end{array}$ \\
\hline & $a$ & 200 & zero & zero & zero & zero & 2010 & zero & zoro \\
\hline & $G_{3}$ & zero & zero & zero & zero & zero & zeso & zero & $\begin{array}{l}4,975 \\
7,726 \\
7,665 \\
4,592\end{array}$ \\
\hline \multirow{4}{*}{$\begin{array}{c}\text { Oel } \\
\text { contendo } \\
\text { Lecitinn }\end{array}$} & 4 & zero & $\begin{array}{l}1,9552 \\
1,8557 \\
1,8744 \\
2,0209\end{array}$ & $\begin{array}{l}2,1405 \\
2,2400 \\
2,1517 \\
2,3010\end{array}$ & $\begin{array}{l}2,6640 \\
2,9938 \\
29503 \\
2,5871\end{array}$ & $\begin{array}{l}3,6400 \\
3,9000 \\
3,4577 \\
3,3955\end{array}$ & $\begin{array}{l}4,0005 \\
5,2015 \\
4,7640 \\
5,0622\end{array}$ & $\begin{array}{l}6,6443 \\
6,7562 \\
6,5672 \\
6,3321\end{array}$ & $\begin{array}{l}7,7650 \\
7,8818 \\
7,4403 \\
7,3035\end{array}$ \\
\hline & $L_{a}$ & zero & $\begin{array}{l}1,3470 \\
1,1604 \\
1,1157 \\
1,4055\end{array}$ & $\begin{array}{l}1.7624 \\
1,9552 \\
2,0435 \\
1,7351\end{array}$ & $\begin{array}{l}2,3160 \\
2,4067 \\
2,2674 \\
2,2326\end{array}$ & $\begin{array}{l}3,1990 \\
3,2711 \\
3,0560 \\
3,0250\end{array}$ & $\begin{array}{l}41559 \\
4,038 \\
3,7960 \\
3,707\end{array}$ & $\begin{array}{l}5,9453 \\
6,0162 \\
5,0990 \\
5,7873\end{array}$ & $\begin{array}{l}6,8632 \\
7,1306 \\
7,3881 \\
6,3371\end{array}$ \\
\hline & Lo & zero & zoro & zero & zero & $\begin{array}{l}0,8670 \\
0,8093 \\
0,9714 \\
0.8520\end{array}$ & $\begin{array}{l}1,5945 \\
1,4055 \\
1,4701 \\
1,5299\end{array}$ & $\begin{array}{l}1967 \\
20003 \\
19030 \\
19990\end{array}$ & $\begin{array}{l}3,3930 \\
3,7836 \\
3,2568 \\
3,3500\end{array}$ \\
\hline & 4 & zero & zero & $z=50$ & zero & zero & zero & zero & $\begin{array}{l}0,7687 \\
0,6741 \\
0,7836 \\
0,8458\end{array}$ \\
\hline
\end{tabular}


Tabela 21 - Valores de penetrafáo transcutanea $\ln v i t r o$ da $D\left(\mu g / \mathrm{cm}^{2}\right)$ das formulaçes de gel hidrófile contendo uréia ou lecitina

\begin{tabular}{|c|c|c|c|c|c|c|c|c|c|}
\hline & & \multicolumn{8}{|c|}{ 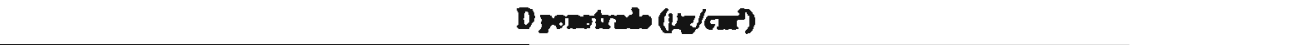 } \\
\hline \multicolumn{2}{|c|}{ Tempo ond } & 0 & 2 & 4 & 6 & 8 & 10 & 12 & 24 \\
\hline \multirow{5}{*}{$\begin{array}{c}\text { Oll } \\
\text { contendo } \\
\text { Urtin }\end{array}$} & $G$ & zero & $\begin{array}{l}0,535 \\
0,734 \\
0,755 \\
0,552\end{array}$ & $\begin{array}{l}0,767 \\
0,775 \\
0,757 \\
0,805\end{array}$ & $\begin{array}{l}0,904 \\
0,913 \\
0,969 \\
0,923\end{array}$ & $\begin{array}{l}1,041 \\
1,051 \\
1,058 \\
1,014\end{array}$ & $\begin{array}{l}1,315 \\
1,414 \\
1,240 \\
1,285\end{array}$ & $\begin{array}{l}1,899 \\
1,839 \\
1,590 \\
1,638\end{array}$ & $\begin{array}{l}4894 \\
5,410 \\
4801 \\
4688\end{array}$ \\
\hline & $G$ & zero & $\begin{array}{r}1,302 \\
1,163 \\
1,200 \\
1,55 \\
\end{array}$ & $\begin{array}{l}2,035 \\
2,146 \\
1,908 \\
1,862\end{array}$ & $\begin{array}{l}2418 \\
2.41 \\
2200 \\
2235\end{array}$ & $\begin{array}{l}3,022 \\
2924 \\
2,853 \\
2988\end{array}$ & $\begin{array}{l}3,392 \\
3,545 \\
3,349 \\
3,359\end{array}$ & $\begin{array}{l}4,400 \\
4,701 \\
4709 \\
4,411 \\
\end{array}$ & $\begin{array}{l}7.200 \\
7.376 \\
7.00 \\
6.754\end{array}$ \\
\hline & $G$ & 2ero & $\begin{array}{l}2,576 \\
2,180 \\
2,338 \\
2,728\end{array}$ & $\begin{array}{l}3,602 \\
3.92 \\
3,905 \\
3,351\end{array}$ & $\begin{array}{l}5.187 \\
5261 \\
5.600 \\
5,353\end{array}$ & $\begin{array}{l}6,195 \\
6,505 \\
6,642 \\
6,332\end{array}$ & $\begin{array}{l}7.637 \\
7,521 \\
7,276 \\
7.688\end{array}$ & $\begin{array}{l}7,924 \\
7,800 \\
7,380 \\
8,814\end{array}$ & $\begin{array}{r}9,803 \\
9,303 \\
10,124 \\
9994\end{array}$ \\
\hline & $G_{4}$ & zero & $\begin{array}{l}5.653 \\
5.394 \\
5.025 \\
4.923\end{array}$ & $\begin{array}{l}5.423 \\
5.261 \\
5.088 \\
5.647\end{array}$ & $\begin{array}{l}8,507 \\
8,734 \\
8,619 \\
9,179\end{array}$ & $\begin{array}{l}9.617 \\
9,759 \\
9,502 \\
9.104 \\
\end{array}$ & $\begin{array}{l}10,046 \\
10,078 \\
10,435 \\
10,659\end{array}$ & $\begin{array}{l}11,225 \\
11,400 \\
12,114 \\
11,805\end{array}$ & $\begin{array}{l}14400 \\
15311 \\
14903 \\
14701\end{array}$ \\
\hline & $\mathrm{G}_{3}$ & zero & $\begin{array}{l}7,067 \\
6,629 \\
7,139 \\
6,30\end{array}$ & $\begin{array}{l}7,372 \\
6,878 \\
7,005 \\
7,190\end{array}$ & $\begin{array}{l}8,637 \\
8,757 \\
8,445 \\
8,246\end{array}$ & $\begin{array}{l}8,983 \\
9,415 \\
9,316 \\
9,478\end{array}$ & $\begin{array}{l}11,915 \\
11,980 \\
12,127 \\
11,729\end{array}$ & $\begin{array}{l}16,767 \\
15,149 \\
17,450 \\
15,616\end{array}$ & $\begin{array}{l}22,066 \\
21,400 \\
22,40 \\
22,68\end{array}$ \\
\hline \multirow{4}{*}{$\begin{array}{c}\text { Oel } \\
\text { contendo } \\
\text { Lecitin }\end{array}$} & 4 & zero & $\begin{array}{l}0,7301 \\
0,7861 \\
0,6306 \\
0,7750\end{array}$ & $\begin{array}{l}0,9103 \\
0,9986 \\
1,0211 \\
0,9808\end{array}$ & $\begin{array}{l}1,5323 \\
1,4863 \\
1,5547 \\
1,5050\end{array}$ & $\begin{array}{l}2,4030 \\
2,2074 \\
2,150 \\
2,5881\end{array}$ & $\begin{array}{l}4,0023 \\
4,1567 \\
4,0050 \\
3,9764\end{array}$ & $\begin{array}{l}7,1903 \\
7,0025 \\
7,1517 \\
7,1180\end{array}$ & $\begin{array}{l}10,62 \\
10,78 \\
10,61 \\
10,82\end{array}$ \\
\hline & L & zero & $\begin{array}{l}0.4142 \\
0.4000 \\
0.3609 \\
0.4230\end{array}$ & $\begin{array}{l}0,5162 \\
0,5062 \\
0,4813 \\
0,4813\end{array}$ & $\begin{array}{l}1,2624 \\
1,3619 \\
1,4204 \\
1,5012\end{array}$ & $\begin{array}{l}21368 \\
21400 \\
2,0833 \\
2,0087\end{array}$ & $\begin{array}{l}3.4002 \\
3,3470 \\
3,2736 \\
3.404\end{array}$ & $\begin{array}{l}5.0236 \\
4.8159 \\
48756 \\
4.6704\end{array}$ & $\begin{array}{l}8,432 \\
8,124 \\
8217 \\
8,227\end{array}$ \\
\hline & L. & 2020 & 2000 & 2010 & sero & zero & $\begin{array}{l}1,2624 \\
1,2400 \\
1,3868 \\
1,3619\end{array}$ & $\begin{array}{l}1,8831 \\
2,0187 \\
1,9589 \\
1,8595 \\
\end{array}$ & $\begin{array}{l}3270 \\
3.457 \\
32511 \\
3.3580\end{array}$ \\
\hline & 4 & zero & zero & zero & zero & zero & $\begin{array}{l}0,6405 \\
0,7475 \\
0,8905 \\
0,6169\end{array}$ & $\begin{array}{l}0,9726 \\
0,9988 \\
0,9079 \\
1,0075\end{array}$ & $\begin{array}{l}1,2000 \\
1,2575 \\
1,500 \\
1,4000\end{array}$ \\
\hline
\end{tabular}


Tabela 22 - Valores de penetrafão transcutanea in vitro da TA $\left(\mu \mathrm{g} / \mathrm{cm}^{2}\right)$ das formulaçóes de gel hidrófilo contendo uréia ou lecitina.

\begin{tabular}{|c|c|c|c|c|c|c|c|c|c|}
\hline & & \multicolumn{8}{|c|}{ TA penetrodo $(\mu \mathrm{g} / \mathrm{cm})$} \\
\hline \multicolumn{2}{|c|}{ Tempo (hr) } & 0 & 2 & 4 & 6 & 8 & 10 & 12 & 24 \\
\hline \multirow{5}{*}{$\begin{array}{c}\text { Oel } \\
\text { contendo } \\
\text { Ureis }\end{array}$} & $a_{1}$ & zero & $\begin{array}{l}0,298 \\
0,321 \\
0,274 \\
0,292\end{array}$ & $\begin{array}{l}0,332 \\
0,337 \\
0,335 \\
0,339\end{array}$ & $\begin{array}{l}0,353 \\
0,349 \\
0,361 \\
0,354\end{array}$ & $\begin{array}{l}0,404 \\
0,407 \\
0,373 \\
0,448\end{array}$ & $\begin{array}{l}0,618 \\
1,623 \\
0,572 \\
0,587\end{array}$ & $\begin{array}{l}0,77 \\
0,746 \\
0,744 \\
0,784\end{array}$ & $\begin{array}{l}1,300 \\
1,270 \\
1,240 \\
1,430\end{array}$ \\
\hline & $a_{3}$ & zero & $\begin{array}{l}0,302 \\
0,297 \\
0,282 \\
0,298\end{array}$ & $\begin{array}{l}0,311 \\
0,323 \\
0,315 \\
0,326\end{array}$ & $\begin{array}{l}0,363 \\
0,382 \\
0,349 \\
0,387\end{array}$ & $\begin{array}{l}0,417 \\
0,444 \\
0,448 \\
0,434\end{array}$ & $\begin{array}{l}0,746 \\
0,759 \\
0,780 \\
0,711\end{array}$ & $\begin{array}{l}0,995 \\
1,038 \\
0,984 \\
0,956\end{array}$ & $\begin{array}{l}1,634 \\
1,741 \\
1,704 \\
1,690\end{array}$ \\
\hline & $O_{3}$ & zero & zero & zero & zero & zero & zero & zero & zero \\
\hline & $a_{4}$ & zero & zero & zero & zero & zero & zero & zero & zero \\
\hline & Os & zero & zero & zero & zero & zero & $\begin{array}{l}0,280 \\
0,261 \\
0,249 \\
0,230\end{array}$ & $\begin{array}{l}0,660 \\
0,622 \\
0,597 \\
0,585\end{array}$ & $\begin{array}{l}2,080 \\
1,903 \\
1,999 \\
1,984\end{array}$ \\
\hline \multirow{4}{*}{$\begin{array}{c}\text { Oel } \\
\text { contendo } \\
\text { Lecitina }\end{array}$} & $L_{1}$ & zero & $\begin{array}{l}0,4440 \\
0,4167 \\
0,4067 \\
0,4169\end{array}$ & $\begin{array}{l}0,7239 \\
0,7488 \\
0,7127 \\
0,6654\end{array}$ & $\begin{array}{l}1,1082 \\
1,1281 \\
1,0833 \\
1,0970\end{array}$ & $\begin{array}{l}1,2102 \\
1,1480 \\
1,2579 \\
1,2040\end{array}$ & $\begin{array}{l}1,8308 \\
1,8806 \\
1,8246 \\
1,8047\end{array}$ & $\begin{array}{l}2,4291 \\
2,4913 \\
2,4478 \\
2,6206\end{array}$ & $\begin{array}{l}3,5261 \\
3,6157 \\
3,3980 \\
3,3721\end{array}$ \\
\hline & Ls & zero & $\begin{array}{l}0,3047 \\
0,2923 \\
0,3010 \\
0,2799\end{array}$ & $\begin{array}{l}0,4627 \\
0,4739 \\
0,4764 \\
0,4689\end{array}$ & $\begin{array}{l}0,7052 \\
0,6878 \\
0,6978 \\
0,6729\end{array}$ & $\begin{array}{l}1,3321 \\
1,3719 \\
1,2264 \\
1,2077\end{array}$ & $\begin{array}{l}1,7189 \\
1,6256 \\
1,5808 \\
1,6057\end{array}$ & $\begin{array}{l}2,2201 \\
2,4913 \\
2,2301 \\
2,2674\end{array}$ & $\begin{array}{l}2,8085 \\
2,7002 \\
2,5896 \\
2,8159\end{array}$ \\
\hline & Ls & zero & zero & zero & zero & zero & zero & zero & zero \\
\hline & L4 & zero & zero & zero & - & $\begin{array}{l}0,8083 \\
0,8358 \\
0,7550 \\
0,7351\end{array}$ & $\begin{array}{l}1,7500 \\
1,8905 \\
1,8308 \\
1,9316\end{array}$ & $\begin{array}{l}2,7985 \\
2,9104 \\
3,0498 \\
2,7776\end{array}$ & $\begin{array}{l}3,8321 \\
3,9888 \\
3,9070 \\
3,5710\end{array}$ \\
\hline
\end{tabular}


Os dados constantes nas Tabelas anteiores foram representados graficamente, plotando-se no eixo das abscissas (x), os valores de tempo (horas); e nas ordenadas (y), os valores das quantidades de corticosteróide liberados ou penetrado transcutaneamente ao longo do tempo $\left(\mathrm{mg} / \mathrm{cm}^{2}\right)$, para as várias formulafoes desenvolvidas. As Figuras 22 e 23 ilustram as curvas de liberafáo in vitro dos corticosteróides ao longo do tempo para as formulafoes de géis hidrofilos, contendo uréia e lecitina respectivamente. Os resultados de penetraçáo transcutanea dos corticosteroides para estas mesmas formulą̧ঠes, estáo mostrados nas Figuras 24 e 25. 

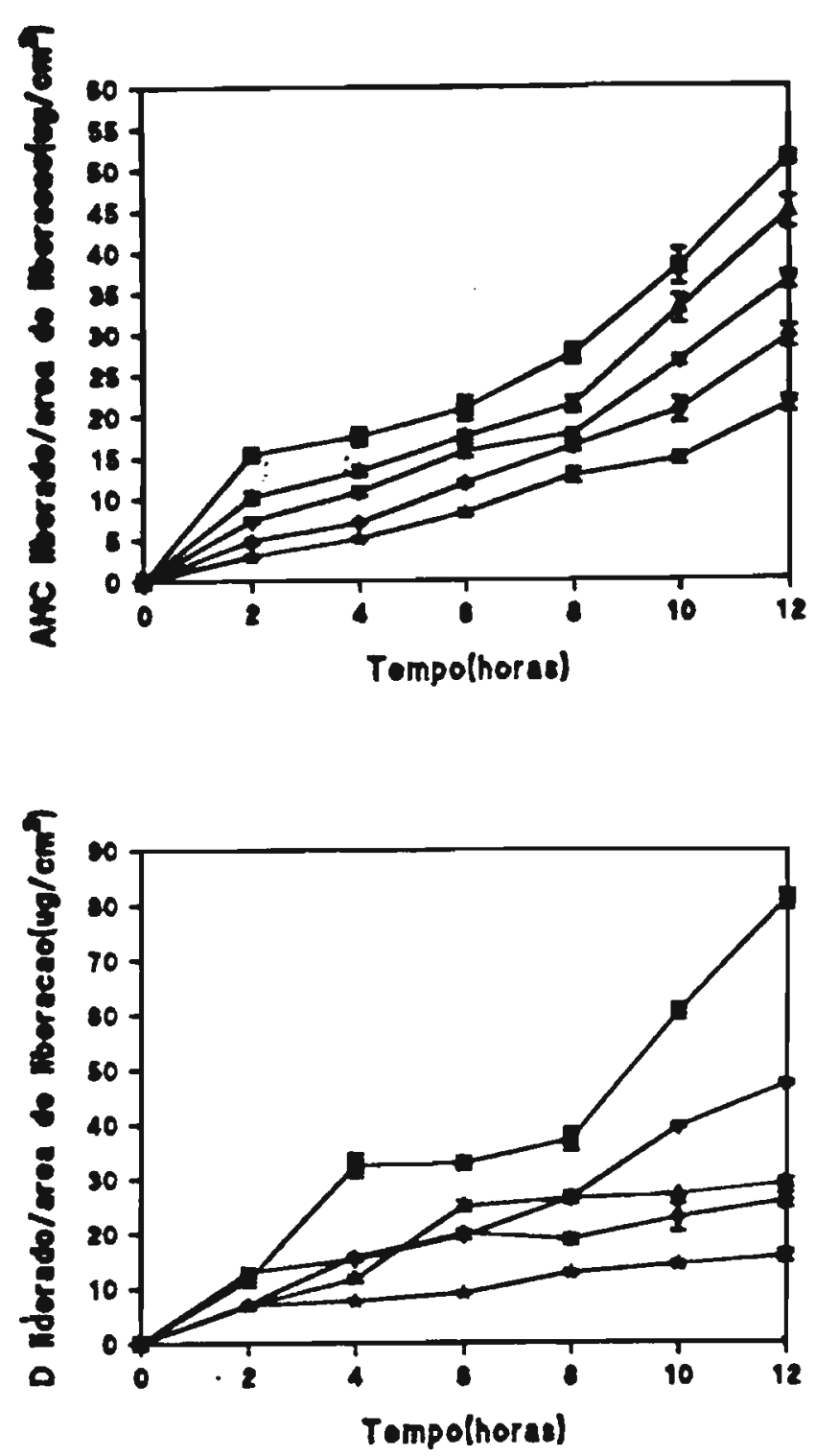
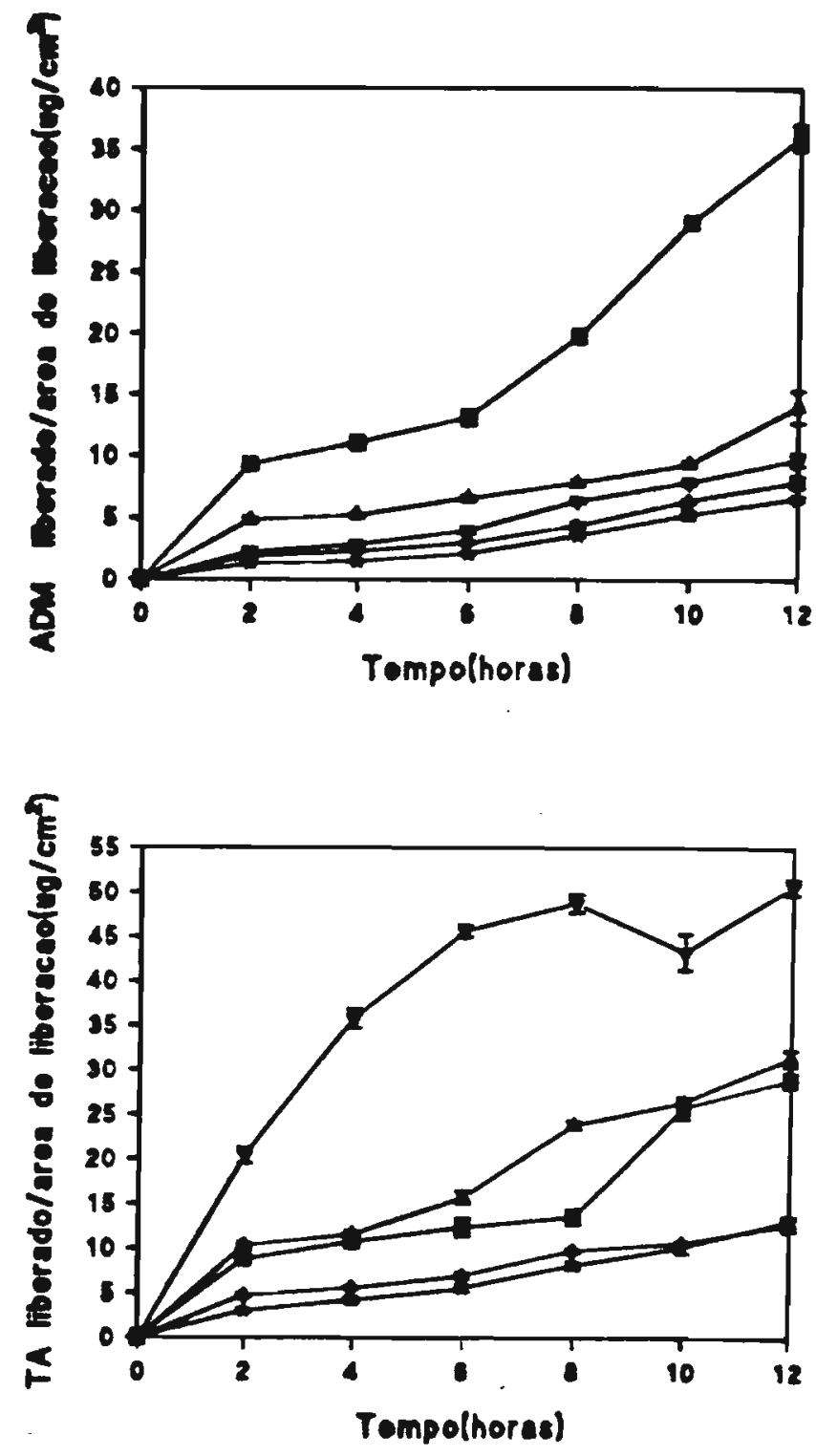

Figura 22 - Liberaço in vitro dos corticosteroides AHC, ADM, D e TA das formulaçoes de gel hidr6filo contendo ureia: $(1) G_{1}, 2,0 \% ;(4) G_{2}, 4,0 \% ;(V) G_{3}, 8,0 \% ;(0) G_{4}, 12,0 \%$; (*) $G_{3}, 15,0 \%$. 

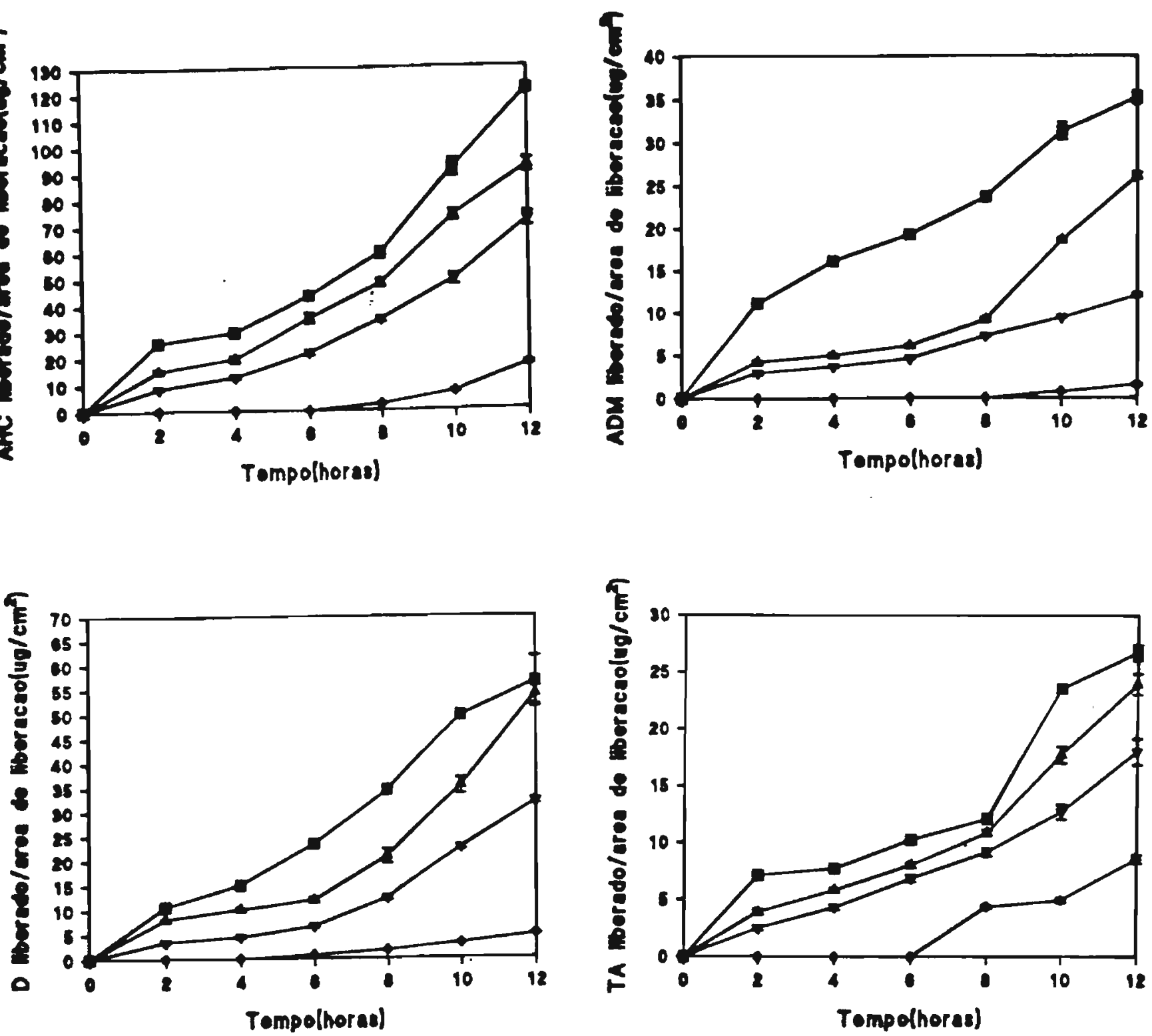

Figura 23 - Liberafáo in vitro dos corticosteroides AHC, ADM, D • TA das formulacoes de gel hidrófilo contendo leciting: (U) L1, 1,0\%; (A) L2, 2,0\%; (V) L3, 4,0\%; (0) LA, 8,0\%. 
106
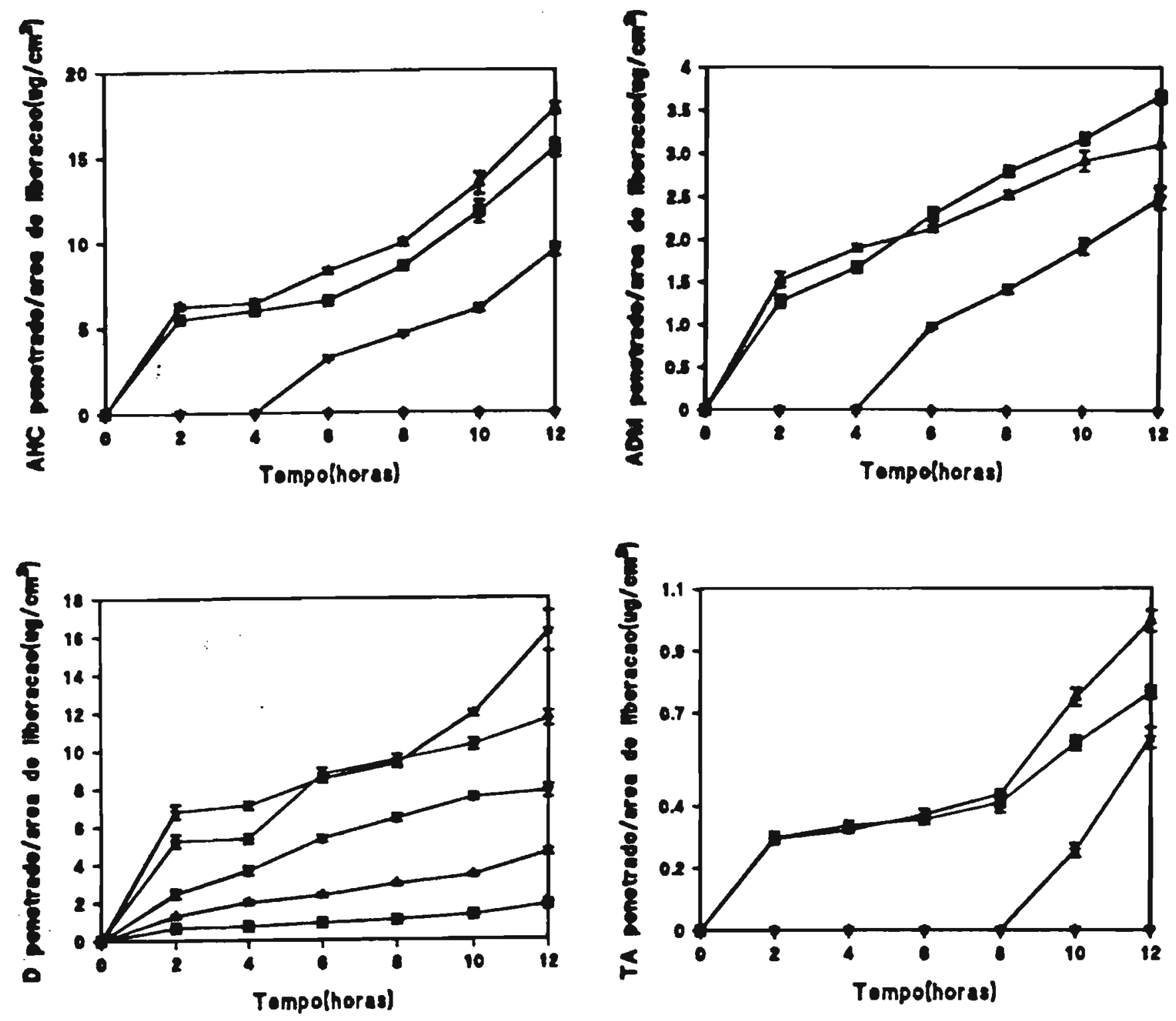

Figura 24 - Penetrafto transcutanea in vitro na pele de cammdongos sem p8lo, dos corticosterbides AHC, ADM, D e TA das formulaçes de gel hidrofilo contendo ureja: ( $(\mathbb{1}) G_{1}$, $2,0 \% ;(A) G_{2}, 4,0 \% ;(V) G_{3}, 8,0 \% ;(1) G_{3}, 12,0 \% ; \bullet(*) G_{3}, 15,0 \%$. 
5
3
8
8
3
8
$\frac{9}{2}$
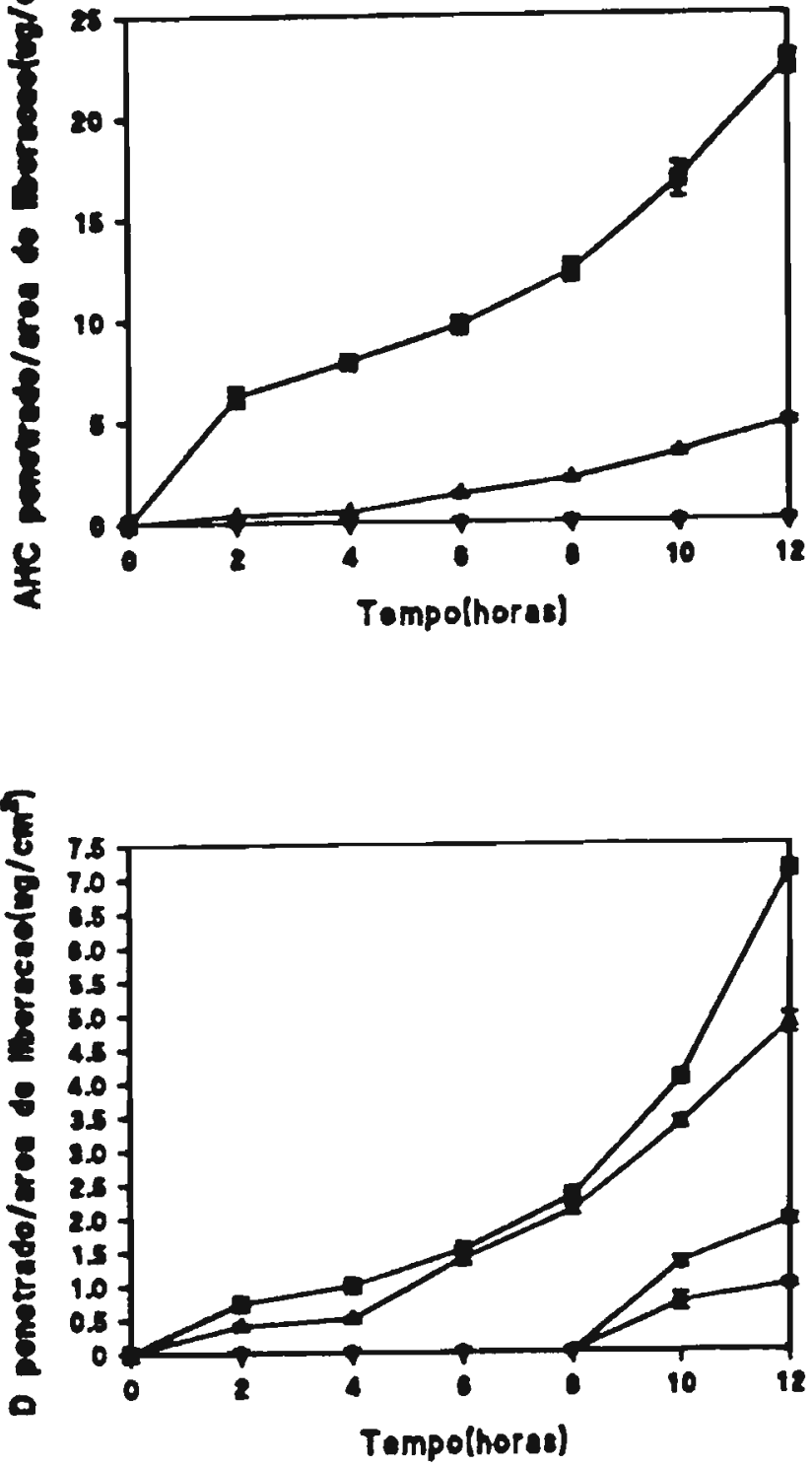
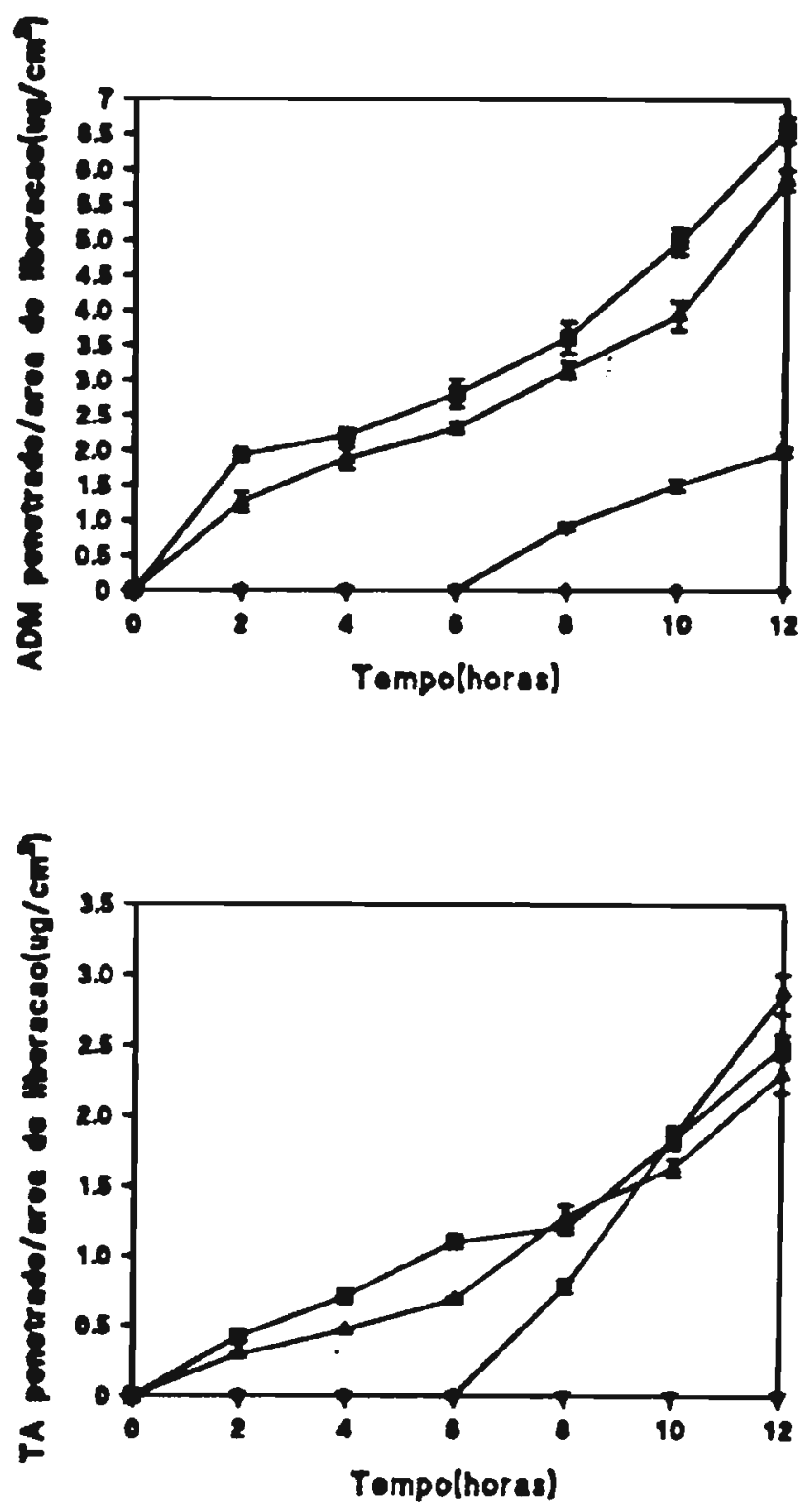

Ifzura 25 - Penetrafgo trenscutanea in vitro, ma pele de cemmodongos sem pelo, dos cortisteróides AHC, ADM, D e TA des formuląoes de gel hidrófilo contendo lecitina: (D) $L_{1}, 1,0 \% ;(\Delta) L_{2}, 2,0 \% ;(\nabla) L_{3}, 4,0 \% ;(0) L_{4}, 8,0 \%$. 
Os parametros cinéticos de liberą̧10 e penetrafto transcutanea in vitro dos corticosterbides AHC, ADM, D e TA das formulafores objetos deste estudo, estro relacionados nas Tabelas 23, 24, 25 e 26.

Tabela 23 - Parâmetros cinéticos das curvas de liberação in vitro dos corticosteróides a partir das formulações de gel contendo uréia.

\begin{tabular}{|c|c|c|c|c|c|c|c|}
\hline \multicolumn{2}{|c|}{ Formulação } & \multicolumn{3}{|c|}{ Modelo HIGUCHI } & \multicolumn{3}{|c|}{ Cinética de $1^{2}$ ordem } \\
\hline & & $\begin{array}{l}\text { Tempo } L A G \\
\text { (horas } 1 / 2 \text { ) }\end{array}$ & $\begin{array}{c}\text { Fluxo } J \\
\left(\mu \mathrm{g} / \mathrm{cm}^{2} / \mathrm{hr}^{2 / 2}\right)\end{array}$ & $\mathbf{r}$ & $\begin{array}{l}\text { Tempo } L A G \\
\text { (horas) }\end{array}$ & $\begin{array}{r}\text { Fluxo J } \\
(\log \mu \mathrm{g} / \mathrm{cn}\end{array}$ & I \\
\hline \multirow{5}{*}{ AHC } & $\mathbf{G}_{1}$ & 0,32 & 12,990 & 0,9313 & 1,29 & 0,054 & 0,9876 \\
\hline & $\mathbf{G}_{2}$ & 0,44 & 11,420 & 0,9134 & 1,13 & 0,064 & 0,9946 \\
\hline & $\mathrm{G}_{3}$ & 0,46 & 9,460 & 0,9218 & 1,04 & 0,068 & 0,9937 \\
\hline & $\mathrm{G}_{4}$ & 0,54 & 7,800 & 0,9153 & 0,84 & 0,079 & 0,9937 \\
\hline & $\mathrm{G}_{5}$ & 0,57 & 5,710 & 0,9158 & 0,63 & 0,084 & 0,9861 \\
\hline \multirow{5}{*}{ ADM } & $\mathrm{G}_{1}$ & 0,42 & 9,560 & 0,9209 & 1,11 & 0,063 & 0,9881 \\
\hline & $\mathrm{G}_{2}$ & 0,20 & 3,430 & 0,9400 & 1,07 & 0,046 & 0,9902 \\
\hline & $G_{3}$ & 0,44 & 2,700 & 0,9385 & 0,48 & 0,068 & 0,9921 \\
\hline & $\mathbf{G}_{4}$ & 0,46 & 2,120 & 0,9215 & 0,20 & 0,066 & 0,9953 \\
\hline & $G_{5}$ & 0,57 & 1,780 & 0,8970 & 0,12 & 0,078 & 0,9897 \\
\hline \multirow{5}{*}{ D } & G1 & 0,45 & 21,170 & 0,9515 & 1,16 & 0,073 & 0,9869 \\
\hline & $G_{2}$ & 0,27 & 9,370 & 0,9708 & 1,14 & 0,061 & 0,9950 \\
\hline & $\mathrm{G}_{3}$ & 0,25 & 12,710 & 0,9893 & 1,21 & 0,059 & 0,9926 \\
\hline & $\mathbf{G}_{4}$ & 0,12 & 7,570 & 0,9873 & 1,27 & 0,047 & 0,9913 \\
\hline & $G_{5}$ & 0,06 & 4,440 & 0,9530 & 1,28 & 0,039 & 0,9839 \\
\hline \multirow{5}{*}{ TA } & $\mathrm{G}_{1}$ & 0,33 & 7,670 & 0,9143 & 1,17 & 0,054 & 0,9886 \\
\hline & $G_{2}$ & 0,27 & 8,860 & 0,9678 & 1,23 & 0,052 & 0,9902 \\
\hline & $G_{3}$ & 0,13 & 15,020 & 0,9651 & 1,63 & 0,032 & 0,9913 \\
\hline & $\mathbf{G}_{4}$ & 0,15 & 3,510 & 0,9828 & 1,11 & 0,045 & 0,9903 \\
\hline & $\mathbf{G}_{5}$ & 0,12 & 11,920 & 0,9440 & 0,74 & 0,064 & 0,9972 \\
\hline
\end{tabular}


Tabela 24 - Parâmetros cinéticos das curvas de liberação in vitro dos corticosteróides a partir das formulações de gel contendo lecitina.

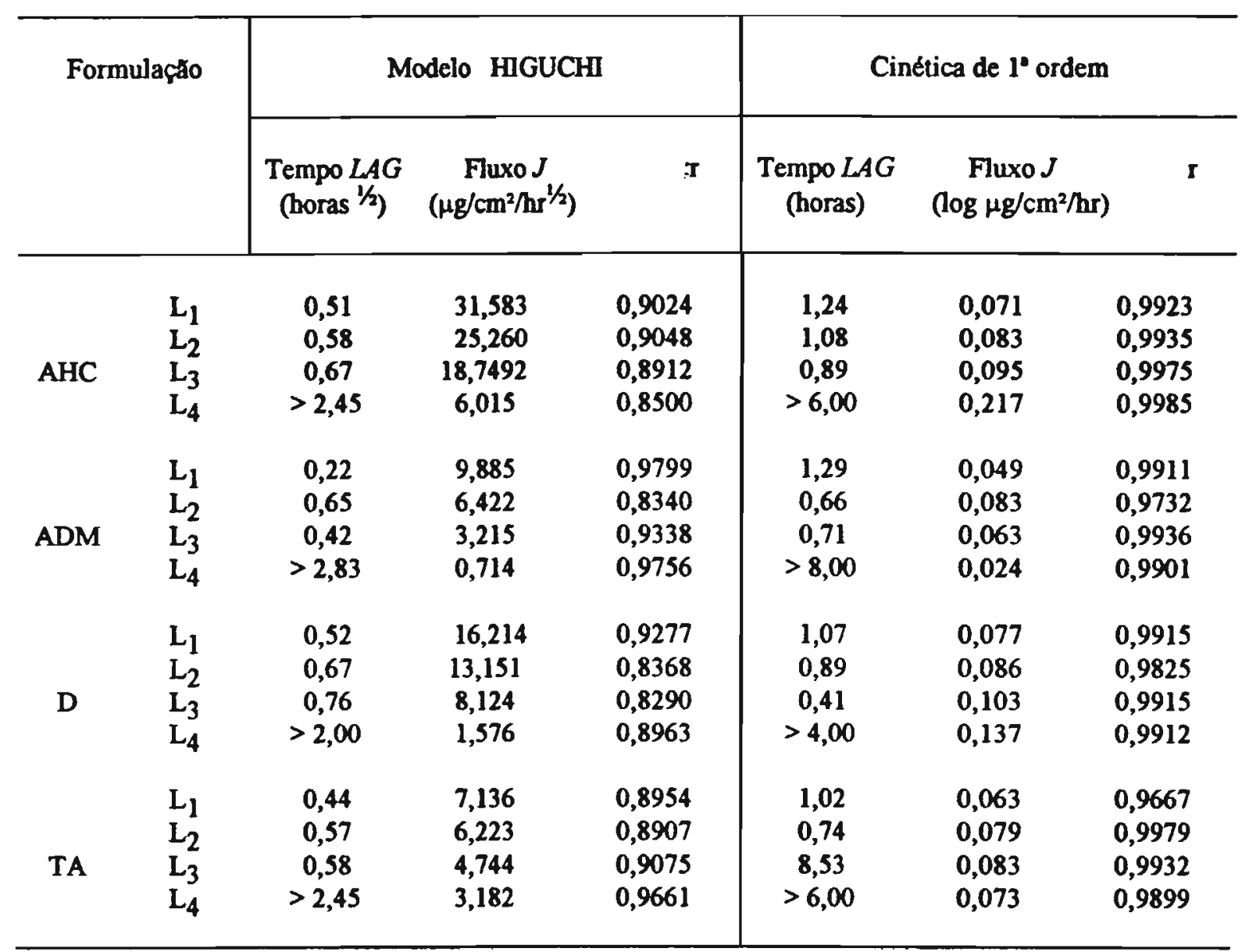


Tabela 25 - Parâmetros cinéticos das curvas de penetração transcutânea in vitro dos corticosteróides a partir das formulações de gel contendo uréia.

\begin{tabular}{|c|c|c|c|c|c|c|c|}
\hline \multicolumn{2}{|c|}{ Formulação } & \multicolumn{3}{|c|}{ Modelo HIGUCHI } & \multicolumn{3}{|c|}{ Cinética de $1^{\mathbb{a}}$ ordem } \\
\hline & & $\begin{array}{l}\text { Tempo } L A G \\
\text { (horas } 1 / 2 \text { ) }\end{array}$ & $\begin{array}{c}\text { Fluxo } J \\
\left(\mu \mathrm{g} / \mathrm{cm}^{2} / \mathrm{hr}^{1 / 2}\right)\end{array}$ & $\mathbf{r}$ & $\begin{array}{l}\text { Tempo } L A G \\
\text { (horas) }\end{array}$ & $\begin{array}{r}\text { Fluxo } \\
(\log \mu g / \mathrm{cn}\end{array}$ & 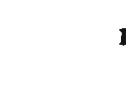 \\
\hline \multirow{5}{*}{ AHC } & $\mathrm{G}_{1}$ & 0,21 & 3,874 & 0,9382 & 1,11 & 0,046 & 0,9914 \\
\hline & $\mathrm{G}_{2}$ & 0,22 & 4,492 & 0,9453 & 1,14 & 0,047 & 0,9873 \\
\hline & $\mathrm{G}_{3}$ & $>2,00$ & 0,843 & 0,9873 & $>4,00$ & 0,077 & 0,9959 \\
\hline & $\mathrm{G}_{4}$ & - & - & - & - & - & - \\
\hline & $\mathrm{G}_{5}$ & - & - & - & - & - & - \\
\hline \multirow{5}{*}{ ADM } & $\mathrm{G}_{1}$ & 0,15 & 1,045 & 0,9922 & 0,01 & 0,046 & 0,9930 \\
\hline & $\mathrm{G}_{2}$ & 0,11 & 0,876 & 0,9947 & 0,66 & 0,031 & 0,9901 \\
\hline & $\mathrm{G}_{3}$ & $>2,00$ & 0,843 & 0,9873 & $>4,00$ & 0,067 & 0,9965 \\
\hline & $\mathrm{G}_{4}$ & - & - & - & - & - & - \\
\hline & $\mathrm{G}_{5}$ & - & - & - & - & - & - \\
\hline \multirow{5}{*}{$\mathrm{D}$} & $\mathrm{G}_{1}$ & 0,17 & 0,459 & 0,9515 & 0,84 & 0,044 & 0,9971 \\
\hline & $\mathrm{G}_{2}$ & 0,24 & 1,219 & 0,9708 & 0,02 & 0,051 & 0,9903 \\
\hline & $\mathrm{G}_{3}$ & 0,19 & 2,386 & 0,9893 & 0,85 & 0,050 & 0,9914 \\
\hline & $\mathrm{G}_{4}$ & 0,01 & 3,326 & 0,9873 & 1,24 & 0,037 & 0,9907 \\
\hline & $\mathrm{G}_{5}$ & 0,05 & 4,002 & 0,9530 & 1,29 & 0,037 & 0,9897 \\
\hline \multirow{5}{*}{ TA } & $\mathrm{G}_{1}$ & 0,125 & 0,191 & 0,9417 & 1,20 & 0,041 & 0,9817 \\
\hline & $\mathrm{G}_{2}$ & 0,351 & 0,246 & 0,8993 & 1,11 & 0,055 & 0,9901 \\
\hline & $\mathrm{G}_{3}$ & - & - & - & - & - & - \\
\hline & $\mathrm{G}_{4}$ & - & - & - & - & - & - \\
\hline & $\mathrm{G}_{5}$ & $>2,83$ & 0,284 & 0,9448 & $>8,00$ & 0,056 & 0,9905 \\
\hline
\end{tabular}


Tabela 26 - Parâmetros cinéticos das curvas de liberação in vitro dos corticosteróides a partir das formulações de gel contendo lecitina.

\begin{tabular}{|c|c|c|c|c|c|c|c|}
\hline \multicolumn{2}{|c|}{ Formulaçăo } & \multicolumn{3}{|c|}{ Modelo HIGUCHI } & \multicolumn{3}{|c|}{ Cinética de $l^{\bullet}$ ordem } \\
\hline & & $\begin{array}{l}\text { Terripo } L A G \\
\text { (horas }{ }^{1 / 2} \text { ) }\end{array}$ & $\begin{array}{c}\text { Fluxo } J \\
\left(\mu \mathrm{g} / \mathrm{cm}^{2} / \mathrm{hr}^{1 / 2}\right)\end{array}$ & $\mathbf{r}$ & $\begin{array}{l}\text { Tempo } L A G \\
\text { (horas) }\end{array}$ & $\begin{array}{r}\text { Fluxo } \\
(\log \mu g / c n\end{array}$ & r \\
\hline \multirow{4}{*}{ AHC } & $\mathrm{L}_{1}$ & 0,33 & 5,809 & 0,9398 & 1,08 & 0,055 & 0,9969 \\
\hline & $\mathrm{L}_{2}$ & 0,77 & 1,269 & 0,8504 & 0,89 & 0,065 & 0,9984 \\
\hline & $\mathbf{L}_{3}$ & - & - & 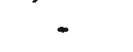 & - & - & - \\
\hline & $\mathrm{L}_{4}$ & - & - & - & - & - & - \\
\hline \multirow{4}{*}{$\mathrm{ADM}$} & $\mathrm{L}_{1}$ & 0,33 & 1,694 & 0,9374 & 0,41 & 0,055 & 0,9930 \\
\hline & $\mathrm{L}_{2}$ & 0,42 & 1,485 & 0,9245 & 0,73 & 0,063 & 0,9958 \\
\hline & $\mathrm{L}_{3}$ & $>2,45$ & 0,793 & 0,9906 & $>6,00$ & 0,086 & 0,9971 \\
\hline & $\mathrm{L}_{4}$ & - & - & - & - & - & - \\
\hline \multirow{4}{*}{$\mathrm{D}$} & $\mathrm{L}_{1}$ & 0,75 & 1,667 & 0,8062 & 0,59 & 0,099 & 0,9943 \\
\hline & $\mathrm{L}_{2}$ & 0,77 & 1,269 & 0,8504 & 0,75 & 0,115 & 0,9885 \\
\hline & $\mathrm{L}_{3}$ & $>2,83$ & 0,958 & 0,9996 & $>8,00$ & 0,084 & 0,9993 \\
\hline & $\mathrm{L}_{4}$ & $>2,83$ & 0,512 & 1,0000 & $>8,00$ & 0,064 & 0,9995 \\
\hline \multirow{4}{*}{ TA } & $\mathrm{L}_{1}$ & 0,49 & 0,657 & 0,9204 & 1,11 & 0,046 & 0,9882 \\
\hline & $\mathrm{L}_{2}$ & 0,64 & 0,615 & 0,8910 & 1,14 & 0,047 & 0,9917 \\
\hline & $\mathrm{L}_{3}$ & - & - & - & - & - & - \\
\hline & $\mathrm{L}_{4}$ & $>2,45$ & 1,108 & 0,9437 & $>6,00$ & 0,141 & 0,9901 \\
\hline
\end{tabular}


A Tabela 27 e 28 mostram os valores de retençáo e penetrafáo transcutânea dos corticosteróides (AHC, ADM, D e TA) de camundongos sem pélo, após 24 h de experimento.

Tabela 27 - Retençáo e penetrą̧̊ transcuthenea, na pele de camundongos sem pêlo, dos cosrticosteróides AHC, ADM, D e TA das formulą̧ðes de géis hidrófilos contendo uréia, após $24 \mathrm{~h}$ de experimento.

\begin{tabular}{|c|c|c|c|c|c|c|c|c|}
\hline \multirow[b]{3}{*}{ Formulaçăo } & \multicolumn{8}{|c|}{ Corticosterólde $\left(\mu / \mathrm{gm}^{2}\right)$} \\
\hline & \multicolumn{2}{|c|}{ AHC } & \multicolumn{2}{|c|}{ ADM } & \multicolumn{2}{|c|}{$\mathbf{D}$} & \multicolumn{2}{|c|}{ TA } \\
\hline & Permeado & Retido & Permeado & Retido & Permeado & Retido & Permeado & Retido \\
\hline & 19,183 & 10,15 & 4,675 & 2,59 & 4,884 & 1,53 & 1,300 & 1,50 \\
\hline$o_{l}$ & 20,991 & 11,03 & 4,801 & 2,65 & 5,410 & 1,63 & 1,270 & 1,70 \\
\hline \multirow[t]{3}{*}{ (2,0\% uretia) } & 21,321 & 9,75 & 4,979 & 2,71 & 4,801 & 1,71 & 1,240 & 1,63 \\
\hline & 20,379 & 10,95 & 4,708 & 2,53 & 4,652 & 1,57 & 1,430 & 1,57 \\
\hline & 25,147 & 13,437 & 4,203 & 3,17 & 7,200 & 2,09 & 1,634 & 1,72 \\
\hline$O_{2}$ & 23,131 & 12,034 & 4,042 & 3,42 & 7,376 & 2,29 & 1,741 & 1,82 \\
\hline \multirow[t]{3}{*}{$(4,0 \%$ urtia $)$} & 24,031 & 12,752 & 4,306 & 3,33 & 7,040 & 2,21 & 1,704 & 1,90 \\
\hline & 24,379 & 13,057 & 4,362 & 3,25 & 6,754 & 2,00 & 1,690 & 1,93 \\
\hline & 13,156 & 16,335 & 3,553 & $\$, 31$ & 9,498 & 2,87 & & 3,11 \\
\hline$\sigma_{3}$ & 13,121 & 15,995 & 3,695 & 3,29 & 9,468 & 2,97 & - & 2,85 \\
\hline \multirow[t]{3}{*}{ (8,0\% urtia) } & 12,995 & 16,046 & 3,806 & 3,72 & 10,124 & 3,00 & & 3,00 \\
\hline & 14,071 & 16,195 & 3,918 & 6,03 & 9,994 & 2,78 & & 2,79 \\
\hline & & 23,431 & & 7,32 & 14,44 & 3,00 & & 3,80 \\
\hline \multirow{4}{*}{$\begin{array}{c}a_{4} \\
(12,0 \% \text { urtia })\end{array}$} & - & 22,991 & - & 8,17 & 13,311 & 3,23 & $\cdot$ & 3,71 \\
\hline & & 21,993 & & 8,99 & 14,963 & 3,40 & & 4,30 \\
\hline & & 24,163 & & 9,07 & 14,701 & 3,30 & & 3,98 \\
\hline & 5,42 & 25,132 & 4,975 & 11,05 & 22,066 & 3,60 & 2,080 & 4,95 \\
\hline$a_{3}$ & 6,01 & 23,952 & 4,726 & 10,11 & 21,480 & 3,57 & 1,903 & 4,60 \\
\hline \multirow[t]{2}{*}{$15,0 \%$ urtia } & 4,97 & 24,571 & 4,665 & 9,72 & 22,425 & 3,42 & 1,999 & 5,00 \\
\hline & 4,83 & 24,932 & 4,592 & 9,30 & 22,687 & 3,77 & 1,984 & $4, \pi$ \\
\hline
\end{tabular}


Tabela 28 - Retenfấo e penetrafáo transcutanea, na pele de camundongos sem pe̊lo, dos corticosteroides AHC, ADM, D e TA das formulą̧øes de geis hidrofilos contendo lecitina, após $24 \mathrm{~h}$ de experimento.

\begin{tabular}{|c|c|c|c|c|c|c|c|c|}
\hline \multirow[b]{3}{*}{ Formulaçđ̃o } & \multicolumn{8}{|c|}{ Corticosterólde $\left(\mu / \mathrm{cm}^{2}\right)$} \\
\hline & \multicolumn{2}{|c|}{ AHC } & \multicolumn{2}{|c|}{$\mathbf{A D M}$} & \multicolumn{2}{|c|}{$\mathbf{D}$} & \multicolumn{2}{|c|}{$\mathbf{T A}$} \\
\hline & Permeado & Retido & Permeado & Retido & Permeado & Retido & Perineado & Retido \\
\hline & 26,771 & 23,035 & 7,765 & 8,72 & 10,62 & 2,15 & 3,5261 & 2,91 \\
\hline $\mathbf{L}_{1}$ & 25,180 & 22,851 & 7,882 & 9,07 & 10,78 & $2, \infty$ & 3,6157 & 2,69 \\
\hline \multirow[t]{3}{*}{ (1,0\% lecitina) } & 27,142 & 22,352 & 7.4403 & 9.50 & 10,61 & 2,32 & 3,398 & 2,83 \\
\hline & 24,995 & 24,362 & 7,304 & 9,25 & 10,82 & 2,47 & 3,3721 & 2,73 \\
\hline & 23,451 & 35,661 & 6,8632 & 10,45 & 8,433 & 3,59 & 2,809 & 5,52 \\
\hline $\mathrm{L}_{2}$ & 23,003 & 36,721 & 7,1306 & 12,07 & 8,1244 & 3,60 & 2,700 & 5,30 \\
\hline \multirow[t]{3}{*}{ (2,0\% lecitins) } & 21,965 & 33,210 & 7,388 & 12,00 & 8,2177 & 3,72 & 2,5896 & 5,78 \\
\hline & 22,301 & 34,521 & 6,337 & 11,42 & 8,2276 & 3,87 & 2,816 & 5,62 \\
\hline & 3,205 & 38,620 & 3,393 & 21,95 & 3,2749 & 7,71 & & 12,20 \\
\hline $\mathrm{L}_{3}$ & 3,452 & 40,321 & 3,784 & 22,03 & 3,4577 & 7,52 & - & 11,15 \\
\hline \multirow[t]{3}{*}{ (4,0\% lecitina) } & 3.139 & 41,032 & 3,256 & 24,7 & 3,5211 & 7,69 & & 12,73 \\
\hline & 3,507 & 39,032 & 3,350 & 23,50 & 3,3582 & 7,05 & & 10,93 \\
\hline & 2,321 & 42,033 & 0,7687 & 23,90 & 1,24 & 10,27 & 3,832 & 14,57 \\
\hline$L_{4}$ & 2,507 & 43,071 & 0,6741 & 25,40 & 1,258 & 11,30 & 3990 & 14,72 \\
\hline \multirow[t]{2}{*}{ ( $8,0 \%$ lecitina) } & 2,301 & 40,382 & 0,784 & 26,32 & 1,509 & 11,07 & 3,908 & 14,20 \\
\hline & 2,407 & 41,823 & 0,846 & 25,91 & 1,484 & 9,85 & 3,571 & 15,30 \\
\hline
\end{tabular}


Tabela 29 - Retenf̧lo cutânea, na pele de camundongos sem pêlo, dos corticosteróides AHC, ADM, D e TA da formulaçá controle sem lecitins ap6s $24 \mathrm{~h}$ de experimento.

\begin{tabular}{c|c}
\hline Substâncias Corticosteróide & Corticosteroide retido $\left(\mu \mathrm{g} / \mathrm{cm}^{3}\right)$ \\
\hline AHC & $18,05( \pm 0,053)$ \\
ADM & $5,73( \pm 0,030)$ \\
D & $2,35 \quad( \pm 0,041)$ \\
TA & $3,78 \quad( \pm 0,032)$ \\
\hline
\end{tabular}

Os valores em parênteses representam os desvios padrăo referentes a quatro determinaçóes. 
6 - DISCUSSÃO 
Ao longo da última década, inúmeros pesquisadores foram atrádos a realizarem criteriosos estudos, objetivando determinar e entender os fatores farmacocinéticos, flsicoquímicos e farmacotécnicos, os quais envolvem a ą̧ăo de produtos dermatológicos e de ą̧⿰亻弋o transdérmica

Uma vez que a administrafăo de produtos medicamentosos pela via cutânea destina-se a obtençáo, tanto de uma afáo tópica (produto de ação dermatológica) como também sistêmica (produto transdermal), é primordial que se tenha uma concreta definif̧áo de qual destas açes é desejada, visto que, os critérios para avaliaça destes produtos sáo conceitualmente diferentes. Um produto dermatológico é destinado a liberar o(s) princípio(s) ativo(s) na pele para o tratamento de patologias cutâneas, sendo assim, a pele é o orgâo alvo. Deste produto exige-se uma máxima atuafáo na pele e mínima exposiçáo à toxicidade sistêmica, ou seja, é ideal que se tenha uma btima retenfão do fármaco na pele, com pequeno ou inexistente fluxo através dela (112).

Desde 1952 os corticosteróides têm ocupado uma posição de destaque entre as medicaçช́es anti-inflamatórias usadas para o brotamento de várias patologias cutâneas, tais como, dermatites, eczemas, intertrigem, psoriase, pitiríase, pruridos etc (69). Entretanto, so lado da atividade tópica, estes principio-ativos podem apresentar efeitos colaterais decorrentes, principalmente, de sua absorçăo sistêmica através da pele, fato este que está relacionado com a composiçáo do veiculo $(90,107)$.

Na avalią̧́ da açáo de produtos de afáo dermatológica e transdermais, testes clínicos podem ser precedidos, e em algumas vezes substituldos, por testes in vitro. Estes testes, devido as suas peculiaridades, permitem entender os fenómenos fisico-químicos que ocorrem entre a aplicąáa do produto e o efeito medido farmacológica- ou clinicamente, de maneira prática, rápida e sem a interferência de fatores biológicos (131).

As colocafðes feitas acima levou-nos ao estudo de bases dermatológicas para a incorporafá de corticosteroides, as quais proporcionassem uma disponibilidade adequada a estes fărmacos, uma máxima retençăo, e mínimo fluxo dos mesmos atravês da pele. Assim, a obtenção de produtos com efeitos colaterais mínimos seria otimizada. 
Para viabilizar nossos objetivos, a princípio, procurou-se fazer uso de bases inócuas, com propriedades organolépticas e fisico-químicas adequadas e compativeis com os corticosteróides. Estes requisitos levaram-nos a estudar géis hidrófilos formados por uma sequesncia de co-polímeros (POE/POP/POE), mais especificamente o Poloxamer 407. Este copolímero, apresenta gelatinização térmica reversível em concentraçరes superiores a $20 \%$, e por isso foram considerados veículos potenciais para a liberaça de fármacos.

Associado a base que forma o produto dermatológico, foi desejável a presença de adjuvantes que promovam adequadas liberaçáo e penetraçáo cutaneas. Assim, o uso de substancias "promotoras de absorção cutânea" se fez necessário. Várias substancias químicas te̊m sido estudadas e empregadas com esse propósito, como por exemplo, o dimetilsulfoxido, a dimetilfornamida, os agentes tensoativos, os dissolventes (propilenoglicol, álcoois etc), ácidos graxos etc $(1,8,26,29,53,54,57,80,103)$. Estretanto, ao lado da funçáo de aumentar a penetraçăo cutânea dos fărmacos, tem-se 0 inconveniente da irritafăo que estas substâncias causam à pele (43).

Nos estados patológicos da pele onde é indicado o uso de produtos contendo corticosteróides, o local doente, apresenta-se irritado, com pruridos e, até mesmo, com feridas expostas (69). O uso de produtos que sejam irritantes é totalmente inadequado. Este fato conduziunos a selecionar substâncias "promotoras de absorçáo cutânea", as quais fossem inócuas e compatíveis com o tecido cutâneo. Duas substâncias preencheram plenamente estes requisitos, a

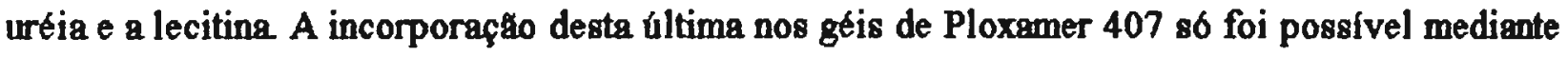
a adiçáo de um componente oleoso (vaselina líquida). Assim, obtiveram-se, na verdade, produtos leitosos, decorrente da emulsificaçá da vaselina líquida na base de gel hidrófilo.

Quatro corticosteroides foram incorporados, separadamente e em concentrafoes adequadas, nas formulą̧øes de geis contendo uréia ou lecitina, sendo dois fluorados (ADM e TA) e dois năo fluorados (AHC e D).

Obtidas as formulaçбes, foram avaliados os partmetros fisico-químicos, pH e reologia. Os géis hidrófilos contendo uréia e lecitina apresentaram valores de pH variando de 5,7 a 6,3 e de 5,9 a 6,2 , respectivamente. Estes valores såo compativeis com a pele e a presença dos 
diferentes corticosterbides nấo alterou o $\mathrm{pH}$ das formulą̧̌es. Tal fato pode ser atribuído a natureza neutra desses princípios ativos.

A verificąَ̧o do comportamento reológico de produtos semi-solidos é importante, por: $(6,92)$ :

- Ajudar a entender a natureza fisico-química do veículo;

* Controlar a qualidade das formulafres teste e produto final quanto ao processo de fabricą̧ão;

* Estudar os efeitos das alterafóes na formulafores, da temperatura e do tempo de armazenagem em um produto;

* Investigar a capacidade do veículo em suspender sólidos ou líquidos imisciveis;

* Ensaiar uma formulą̧̧o tópica com respeito ao uso pelo paciente, isto é, remoçấo do produto do material de embalagem, aderência e espalhabilidade na pele, etc;

- Verificar o efeito da consistência do produto na liberafăo e absorçăo percutânea de fármacos.

Conforme se pode observar na Tabela 6, o aumento da concentrafáo de adjuvante acarretou num aumento da viscosidade das formulaçбes de géis contendo ureia ou lecitina Este comportamento pode ser explicado pela diminuiçáo do conteúdo de água da preparaf̧â, decorrente do aumento da concentraffí de uréia ou lecitina. Além disto, tais adjuvantes năo apresentaram incompatibilidade fisica com a estrutura do co-polímero.

Analisado os reogramas obtidos, pode-se, verificar que as preparafoes exibiram um comportamento de fluxo năo Newtoniano, do tipo pseudoplástico com Valor de Rendimento. $O$ Valor de Rendimento pode ser definido como sendo o mínimo valor de stress necessário para que um produto comece a fluir ou deformar (6). Como pode ser observado, as curvas náo iniciaram da

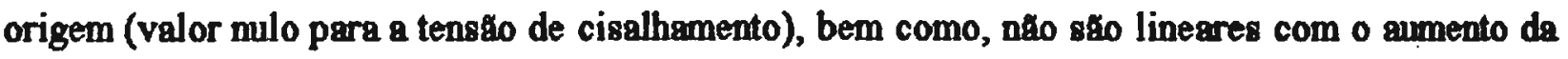
tensão de cisalhamento, caracterizando assim, um fluxo do tipo pseudoplástico com Valor de Rendimento. 


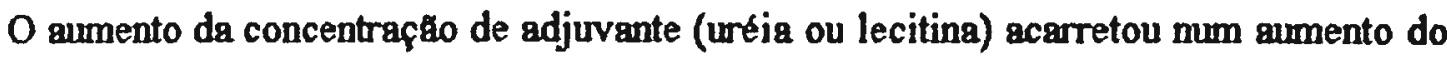
Valor de Rendimento. Este fato pode ser atribuído a um aumento da resistencia da estrutura do gel diante de uma força, comportamento este que pode ajudar a manter um produto semi-sólido sobre a pele, evitando seu escorrimento. Quando este produto é espalhado sobre a ǵrea doente, com uma força que exceda o Valor de Rendimento, a preparaf̧a flui.

A tixotropia das amostras foi determinada pela Área de Histerese que as curvas dos reogramas produziram. De maneira geral, o aumento da concentraçæo de uréia diminuiu a tixotropia dos geis. Comportamento oposto foi observado nos geis contendo lecitina, fato este que pode ser atribuido a emulsificą̧⿰丿丶⿸⿴巳一丶 da vaselina pela lecitina

Sendo o principal objetivo de nosso trabalho a verificafáo da liberafáo e penetrafáo transcutânea dos corticosteróides AHC, ADM, D e TA, presentes nos géis contendo uréia ou lecitina, foi de fundamental importancia padronizar um método in vitro adequado, o qual pudéssemos obter dados efetivos e seguros.

O fato de nåo existir uma metodologia oficial para estudos de liberafáo in vitro de produtos tópico dificultou nosso trabalho a princípio. A célula de difusáo $n^{\circ} 1$ (Figura 8 ) foi projetada baseando-se no modelo de TURAKKA et al. (129) e modificado por BADRA et al. (4). Tal aparelho năo apresentou uniformidade de agitaçă, nem controle da temperatura interna e da velocidade do agitador magnético. A célula de difusão $n^{\circ} 2$ (Figura 9) foi baseada no modelo de FRANZ (34), possui dimensðes menores, o que traduz mma economia de soluçáo receptora e produto a ser aplicado sobre a membrana. Entretanto, foram detectados os mesmos problemas da célula $n^{\circ}$ 1. Em virtude dos resultados obtidos, adsptou-se o modelo de dissoluçáo da Farmacopéia Norte-Americana $(89,98,114)$ para produtos transdermais obtendo a célula $n^{\circ} 3$ (Figura 10). Esta célula de difusâo apresentou temperatura constante $\left(37^{\circ} \mathrm{C}\right)$ e agitą̧áo controlada, estipulada em $100 \mathrm{rpm}$

A qualidade de agitą̧́ é dependente do tipo de agitador empregado. Os agitadores magnéticos causam mistura de fluidos nas proximidades do agitador, mas nå geram movimento lateral do fluido. Assim, os agitadores em forma de pá parecem mais adequado. A soluçåo receptora de uma célula de difiusáo in vitro deve ser adequadamente agitada, evitando-se assim, 
desenvolvimento de concentraf̧es localizadas de fărmacos. A agitaçăo deve ser suficientemente vigorosa para minimizar as camadas de difusáo na interface da membrana, fato este que promoveria uma resistência adicional à difusão do fármaco para a soluç̧o receptora (118).

Uma vez escolhida a célula de difusão para os nossos experimentos, partimos para a seleção da fase receptora e das membranas.

A eleiça de uma solufăo receptora para os experimentos in vitro é critica quando se trabalha com fármacos de baixa solubilidade em água Pode-se obter falsos resultados devido a insolubilidade do fármaco na solução receptora. Trabalhar em "sink conditions" torna-se indubitavelmente necessário para se garantir a obtençáo de resultados efetivos (131).

As soluçరes receptoras mais indicadas sǻ tampరes isotónicos com valores de $\mathrm{pH}$ em torno de 7,2, os quais podem ser acrescidos de co-solubilizadores dos fármacos em estudo (14, $96,108,120)$. Várias substâncias săo utilizadas com este propósito, no entanto, o polietilenoglicol 20 cetil éter parece ser o mais adequado para uso em sistemas de permeacáo $(2,71)$

Conforme pode ser verificado na Tabela 7, a presença do referido tensoativo na concentrafăo de $0,5 \%$, melhorou a solubilidade dos corticosteroides no tampão fosfato isotónico, $\mathrm{pH}=7$,2. Para o AHC e a $\mathrm{D}$ a solubilidade foi duplicada, triplicada para TA, e quadruplicada para o ADM. Assim, garatiram-se condiçðes adequadas para a difusão e solubilizą̧áo destes corticosteróides na soluçá receptora.

A membrana é outro fator crítico na conduçáo dos experimentos de liberaçấo e penetrafâo in vitro. As membranas sintéticas, como as de acetato de celulose, são indicadas para a verificaf̧a das caracteristicas de liberafác que o velculo proporciona ao farmaco. No entanto, trata-se de uma membrana hidrofila que nâo possui as propriedades anatomicas e fisiológicas da pele. Assim, é também necessário realizar estudos com membranas naturais (pele humana ou de animais).

A pele humana decididamente é a mais adequada para estudos in vitro. Entretanto, a dificuldade na aquisif̧̌ deste tecido e a variafăo biológica das amostras de pele, levaram os pesquisadores a empregaram peles de animais $(14,20,27,30,64,94,132,133)$. 
A pele abdominal de camundongos sem pélo tem sido muito utilizada nos experimentos in vitro, apesar de algumas diferenf̧as anatômicas quando comparada com a pele humana $(7,13,30)$. A viabilidade de aquisiça, a melhor uniformidade das amostras, bem como a facilidade de dissecação e separą̧áo do tecido subcutaneo, levou-nos a eleger a pele de camundongos sem pêlo como modelo de membrana para os nossos propósitos (30).

Segundo SHAH et al. (112), nos estudos in vitro, a quantidade de produto a ser aplicado sobre a membrana deveria ser de 1,0 a $3,0 \mu \mathrm{L}$ soluçá $/ \mathrm{cm}^{2}$ ou 1,0 a $3,0 \mathrm{mg}$ semisólido/ $\mathrm{cm}^{2}$. Entretanto, quando o material a ser empregado é semi-sólido, o espalhamento de uma quantidade finita deste produto dificilmente produziria una camada uniforme sobre a membrana. Nesta situaçáo, é aconselhável o uso de "dose infinita", ou seją um excesso de produto (118).

AMERONGEN et al. (2) utilizaram dose infinita em seus estudos de liberą̧⿸厃 in vitro da budesonida contida em cremes, e verificaram que acima de $0,9 \mathrm{~mm}$ de espessura de produto sobre a membrana o perfil de liberaça do fămaco nåo apresentou diferença Baseado nisto, trabalhamos com dose infinita de géis contendo uréia ou lecitina, utilizando um volume de $1,5 \mathrm{~mL}$.

A base dos experimentos in vitro de liberafáo e penetracão transcutânea é determinar as pequenas quantidades de fármaco que atravessam as membranas ou que ficam retidos nas mesmas. O desenvolvimento de um método analítico especiffico e sensível, o qual viabilizasse nossos experimentos, foi considerado extremamente importante.

Para estudo in vitro, dois métodos analíticos sâo indicados, o radioimunoensaio e a CLAE (112). Neste trabalho a CLAE apresentou-se mais adequada para nossos experimentos. A metodologia analítica padronizada foi baseada no método proposto por TOOTHAKER et al. (127). Uma vez que os quatro corticosteróides empregados seriam quantificados separadamente, procurou-se padronizar uma metodologia analítica comum para essas substáncias. Assim, fixamos uma única fase móvel, metanol: $\mathrm{H}_{2} \mathrm{O}(60: 40)$, e utilizamos um corticosteróide como padráo interno do outro.

As Figuras 14, 15, 16 e 17 ilustram os cromatogramas obtidos pela extracto dos corticosteróides na solucta receptora. Como se pode observar, obtiveram-se boas resolufáo e separafáo dos picos cromatográácos. A recuperacáo relativa $(\mathrm{Rr})$ foi adequada, variando-se de 
88,81 a $97,31 \%$, resultados estes considerados adequados para um processo extrativo. A metodologia analítica desenvolvida apresentou linearidade $n a$ faixa de 50,0 a $600,0 \mathrm{ng}$ ( $\mathrm{r}=$ $0,9998)$ para o $\mathrm{AHC}$; de 50,0 a 800,0 ng ( $r=0,9997)$ para o $\mathrm{ADM}$; de 10,0 a $500,0 \mathrm{ng}$ ( $r=$ $0,9949)$ para a TA; e de 25,0 a $500,0 \mathrm{ng}(r=0,9997)$ para a D. Estes resultados mostram que o método por CLAE padronizado foi sensivel e específico.

A determinaça por CLAE dos corticosteróides retidos na pele de camundongos sem pe̊lo foi realizado após extrafáo direta com metanol (102). Este procedimento apresentou-se adequado, uma vez que esses fărmacos sáo solúveis em metanol, e os componentes da pele, que por ventura foram extraidos, năo interferiram no método analítico. O mesmo ocorreu com a deteminaçáo dos corticosterbides contidos nas formulaçøes. Sendo essas preparaçðes de composiçáo simples, totalmente solúveis em metanol, e com componentes que năo interferiram no método, a simples diluiçáo em metanol foi suficiente para uma efetiva extraçáo (Tabela 4).

Definidas as metodologias in vitro e CLAE, os estudos de liberação e penetraçáo transcutânea foram conduzidos. Os dados obtidos foram interpretados segundo dois modelos cinéticos de liberação de fármacos: o de HIGUCHI $(22,45,71,96,111,113)$ e 0 de 1a ordem (100). Analisando as Tabelas 23, 24, 25 e 26 pode-se verificar que o modelo de cinética de 1 a ordem apresentou, em todos os casos, um maior coeficiente de correlaf̧á.

Isto sugere que as formulą̧res testadas seguem cinética de la ordem para a liberafáo e penetraça transcutanea dos corticosteróides. Diante deste fáto, consideramos os dados de tempo $L A G$ e fluxo (J, referentes a este modelo, mais adequados para nossas conclusðes.

Conforme pode ser verificado nas Tabelas 23 e 24 , a concentrafáo dos adjuvantes (uréia e lecitina) interferiram no processo de liberąáo dos corticosterbides.

Nos géis contendo uréia observou-se que o AHC, o ADM e a TA apresentaram uma diminuiça do tempo $L A G$ e aumento do fluxo com o aumento da concentrą̧́o do adjuvante. Para a D, o comportamento foi inverso. A presenfa de lecitina proporcionou um amento do tempo $L A G$ e do fluxo (J) para o AHC, D a TA O ADM apresentou uma diminuiçá do fluxo (J) com o incremento da concentraça de lecitina. 
A cinética de penetraçăo transcutânea das formulaçôes desenvolvidas está demonstrada na Tabela 25 e 26. Para todos os corticosteroides estudados observou-se que o

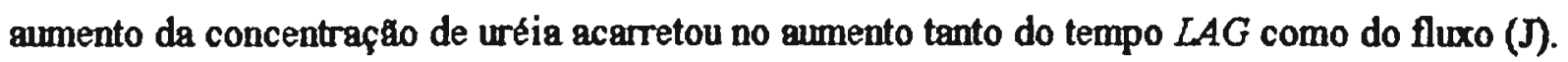

Praticamente, em todas as formulafoes contendo lecitina, o aumento da concentrafaso deste adjuvante proporcionou um aumento do tempo $L A G$ e do fluxo (J), sendo este último parametro diminuido para a $\mathrm{D}$.

Nos estudos in vitro de produtos dermatológicos, é importante considerar que as concentraçбes de fármaco na soluçáo receptora năo refletem, por si só, a influência da formulą̧áo na atividade do produto. Assim, a determinaçáo da quantidade de fărmaco retida na membrana natural leva a dados mais concretos, os quais podem elucidar o grau de atividade tópica do produto. Esta técnica tem sido empregado por muitos autores quando do estudo de penetraça cutânea de fármacos $(22,71,86,95,102)$.

As Tabelas 27 e 28 descrevem os valores das quantidades de cada corticosteróide permeadas e retidas na pele de camundongo sem pêlo, após 24 horas, para as diferentes formulą̧res testadas. Esses resultados podem ser melhor visualizados quando plotamos tais quantidades em funç̃o da concentrafão de adjuvante (Figura 30 e 31). Analisando estes gráficos verificou-se que para todos os corticosteroides, o aumento da concentrafáo de uréia ou lecitina, levou a um aumento da quantidade de fármaco retido, após 24 horas de experimento. 

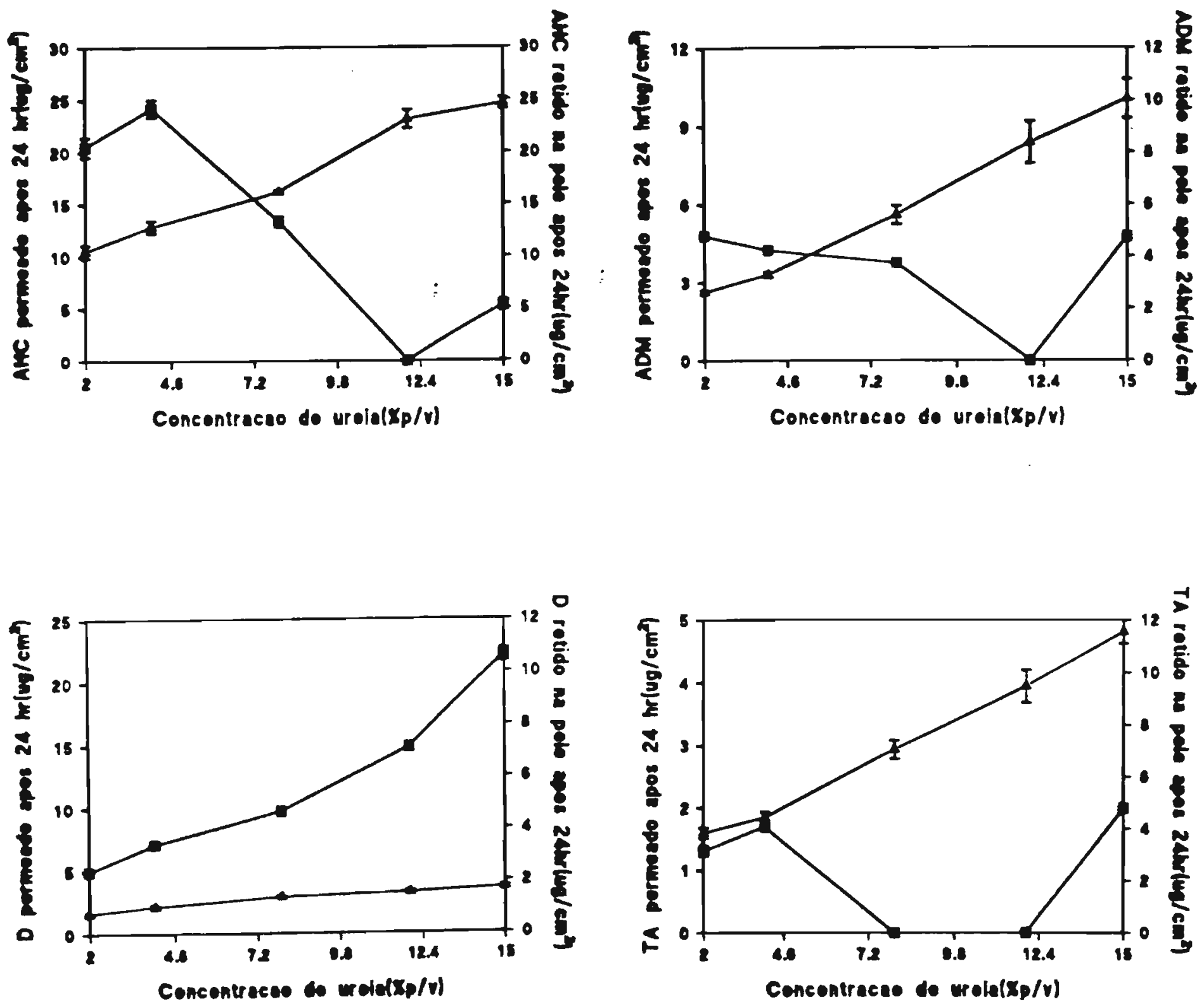

Figura 30 - Quentidade de corticosteroide retido (A) e penetrado (H) versus a concentrafáo de uréia nos géis hidrofflos. 

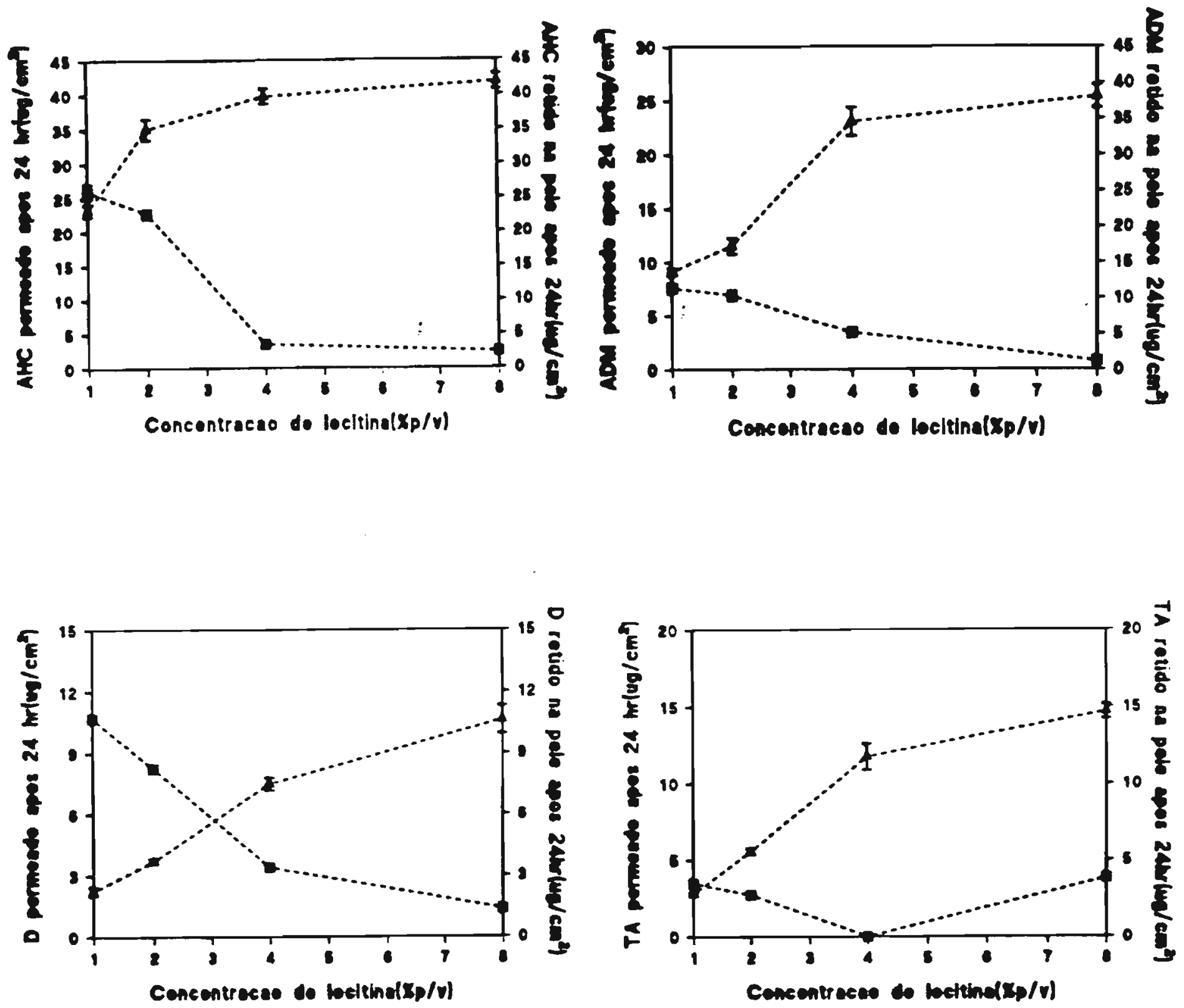

Figura 31 - Quantidade de corticosterbide retido $(A)$ e penetrado $A$ versus a concentraçio de lecitina nos géis hidroffilos. 
A permeaça ou penetraçåo transcutânea, na majoria das vezes, diminuiu com o aumento da concentraçáo de adjuvante, chegando até mesmo a uma ausência de permeaçáo. Uma exceçáo foi observada para a D presente nos géis contendo uréia, onde o aumento da concentraçăo do adjuvante aumentou a penetraçăo transcutânea do fármaco.

Como foi exposto anteriormente o objetivo principal deste trabalho foi desenvolver formulafðes de géis de co-polímero (POE/POP/POE) contendo uréia ou lecitina, os quais proporcionassem efeitos sistêmicos mínimos. Assim, foram selecionadas preparą̧̋́es que apresentaram uma máxima retençúo cutânea associada a um mínimo ou inexistente fluxo dos corticosteróides. As figuras 30 e 31 foram extremamente práticas para este propósito, e o resultados estáo demonstrados na Tabela 30.

Analisando a Tabela 30, quando se compara as formulafroes contendo uréia e as contendo lecitina, estas ultimas apresentaram maior quantidade de corticosteroide retida $\mathrm{O}$ AHC foi retido quase que duas vezes nuais nas formulaf̧es contendo $8,0 \%$ de lecitina $\left(L_{4}\right)$. Esta mesma formulação triplicou a retençáo do ADM na pele de animal, e proporcionou uma retençáo da D 3,6 vezes maior que o gel contendo ureía. A concentraçáo de 4,0\% de lecitina foi suficiente para triplicar a retençá da TA.

A presença da vaselina nas formulą̧ðes de gel com lecitina náo influenciou nestes resultados (Tabela 29). A retençấo cutânea das formulaçסes controle sem lecitina, apresentou valores inferiores quando comparadas com as preparaçбes contendo lecitina

Associar a melhor atuafáo das formulą̧res contendo lecitina ao comportamento reológico poderia ser uma alternativa A lecitina aumentou a tixotropia das formulą̧̃es, consequentemente a difusáo dos corticosteróides estaria facilitada. Entretanto, 0 aumento da viscosidade também foi observado, e isto é um fator que compromete a difusåo de um fărmaco através do vécculo.

Correlaciona o comportamento reológico com os resultados de liberą̧á, penetrą̧áo

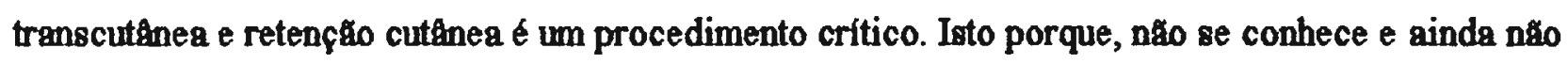
é possivel determinar o real comportamento reológico do produto quando dos experimentos in 
vitro. A literatura ainda nấ mostra uma relą̧áo matemática satisfatória para correlacionar disponibilidade do fármaco na pela com o comportamento reológico de semi-sólidos (6).

Uma explicąa plausível para este comportamento poderia estar findamentada nos mecanismos de açáo que estes adjuvantes possuem como promotores de absorf̧áo cuthnea. 


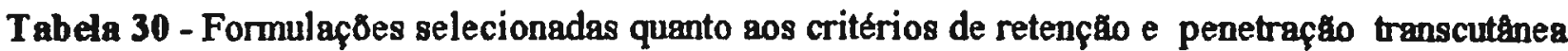
dos corticosteroides.

\begin{tabular}{|c|c|c|c|c|}
\hline \multirow{3}{*}{$\begin{array}{l}\text { Corticoster } \\
\text { oide }\end{array}$} & \multicolumn{4}{|c|}{ ADJUVANTE } \\
\hline & \multicolumn{2}{|c|}{ Uréia } & \multicolumn{2}{|c|}{ Lecitina } \\
\hline & $\begin{array}{l}\text { Formulaçăo } \\
\text { selecionada }\end{array}$ & $\begin{array}{l}\text { Quantidade reti-da } \\
\qquad\left(\mu g / \mathrm{cm}^{2}\right)\end{array}$ & $\begin{array}{l}\text { Formulaçăo } \\
\text { selecionada }\end{array}$ & $\begin{array}{c}\text { Quantidade reti-da } \\
\left(\mu / \mathrm{cm}^{3}\right)\end{array}$ \\
\hline AHC & $\begin{array}{c}\mathbf{G}_{4} \\
(12,0 \% \text { uréia })\end{array}$ & $\begin{array}{c}23,14 \\
( \pm 0,454)\end{array}$ & $\begin{array}{c}\mathrm{L} \\
(8,0 \% \text { lecitin } \mathrm{r})\end{array}$ & $\begin{array}{c}41,83 \\
( \pm 0.554)\end{array}$ \\
\hline ADM & $\begin{array}{c}\mathrm{G}_{4} \\
(12,0 \% \text { uréia })\end{array}$ & $\begin{array}{r}8,38 \\
( \pm 0,405)\end{array}$ & $\begin{array}{c}\text { L. } \\
(8,0 \% \text { lecitina })\end{array}$ & $\begin{array}{c}25,38 \\
( \pm 0,529)\end{array}$ \\
\hline D & $\begin{array}{c}\mathrm{G}_{3} \\
(8,0 \% \text { uréia })\end{array}$ & $\begin{array}{c}2,91 \\
( \pm 0,117)\end{array}$ & $\begin{array}{c}\mathrm{L} \\
(8,0 \% \text { lecitina })\end{array}$ & $\begin{array}{c}10,62 \\
( \pm 0,339)\end{array}$ \\
\hline TA & $\begin{array}{c}\mathrm{G}_{4} \\
(12,0 \% \text { uréia })\end{array}$ & $\begin{array}{c}3,95 \\
( \pm 0,130)\end{array}$ & $\begin{array}{c}\mathrm{L}_{3} \\
\text { (4.0\% lecitina) }\end{array}$ & $\begin{array}{c}11,75 \\
( \pm 0,428)\end{array}$ \\
\hline
\end{tabular}

Os valores em parênteses representam os desvios padrø̃o referentes a quatro determiną̧бes.

A uréia, por ser uma substância hidrófila, atuaria pela rota polar, aumentando a hidratafáo do estrato córneo. Outro modo de afão da uréia é a sua suave aqua queralolítica na pele, a qual poderia diminuir a barreira do extrato córneo a entrada de substâncias na pele. A uréia está presente na composiçáo do Fator de Hidratą̧ão Natural (FHN) da pele, e năo é irritante em altas concentrą̧రes (6). 
A lecitina atuaria pela rota lipidica, interagindo com os fosfolipideos da pele, atuando, assim, como verdadeiro correador de princípios ativos lipofilos. Vários autores empregaram com sucesso este adjuvante como promotor de absorção em vias de administrą̧áo tópicas $(23,31,56,76,130)$.

Os coeficientes de partiçáo óleo/água podem explicar o grau de interaçáo destas substancias com a pele e com o veiculo empregado. Entretanto, considerą̧̋́es teóricas năo săo aconselháveis, uma vez que substancias com altos valores de coeficiente de partição podem nâo traduzir uma alta interaçáo das mesmas na pele. Nestes casos, o veiculo e adjuvantes interferem significativamente na liberaçăo e retenção cutanę, como foi observado no decorrer deste trabalho. Por exemplo, o fáto do ADM ter o maior coeficiente de partiçáo oleo/água, ou seja 31, 92, nåo evitou que sua retençăo cutânea sofresse interferência dos adjưantes.

Somente, a realização de testes de liberafão in vitro com membranas sintéticas, não é aconselhável para estudos de produtos dermatológicos. É necessário, também, conduzir experimentos in vitro de penetraça transcutânea e retencăo com membranas naturais. Isto porque, as características de uma formulação podem não ter uma correlação direta com a disponibilidade do fármaco na pele e vice-versa. Assim, os dados de liberaçấ, penetraçâo transcutânea e retençâo devem ser analisados em conjunto, no sentido de se evitar falsas conclusðes.

A contribuifáo da metodologia in vitro para a Farmacotécnica é inquestionável, pois representa um procedimento prático, rápido e de baixo custo. Os estudos in vitro, mencionados ao longo deste trabalho, também possuem aplicąáo no controle de qualidade de uniformidade de lotes de produtos dermatológicos na Indústria Farmacêutica. Entretanto, deve-se ter cautela quando da extrapolaçáo dos resultados obtidos para situą̧бes in vivo. Com a metodologia in vitro podese fazer um prévio selecionamento das formulą̧res antes da aplicą̧a de testes clínicos.

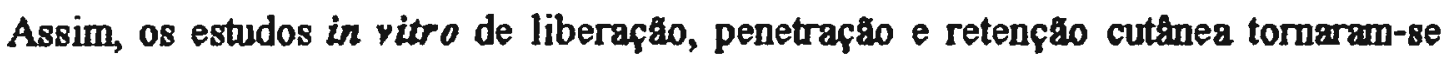
necessários para o desenvolvimento de formulą̧бes dermatológicas efetivas, seguras e com caracteristicas fisico-químicas bem definidas. 
7 - CONCLUSÕES 
A realizacáo deste trabalho levou as seguintes conclusðes:

1 - A medotologia analítica in vitro padronizada mostrou-se adequada para a verificacáo da liberaçăo, penetraçăo transcutânea e retençấ cutânea de corticosteróides contidos em formulaçőes tópicas.

2 - A uréia e a lecitina foram eficazes como promotores de absorçăo cutânea para os corticosteróides testados. A concentraf̧́⿴囗十 desses adjurantes no gel de Poloxamer 407 interferiu nos parâmetros avaliados.

As liberą̧óes e a penetração transcutânea dos corticosteróides contidos nas formulaçoes desenvolvidas obedeceram cinética de 1a ordem.

3 - A concentraçáo de $12,0 \%$ de uréia foi efetiva para a AHC, o ADM, a a TA, e de 8,0\% para a D. Com relaça a lecitina, a concentraça de $8,0 \%$ foi adequada para o AHC, o ADM e a D, e de $4,0 \%$ para a TA.

4 - De maneira geral, as formulą̧ões selecionadas contendo lecitina apresentaram-se quantitativamente mais eficazes quanto à retenção cutânea dos corticosteróides testados, sendo que a que a presença da vaselina não influenciou neste parદ̂metro.

5 - Os géis de Poloxamer 407 associados com lecitina ou uréia podem ser considerados pontenciajs veículos dermatológicos para a incorporąåo de corticosteróides. 
8 - REFERENCIAS BIBLIOGRAFTCAS 
1 - AKHTER, S.A., BARRY, B.W. Enhanced flurbiprofen permeation through humank skin in: use of N-methyl-2-pyrrolidone (NP), 2-pyrrolidone (2P) and dimethylisosorbide (DS). J. Pharm. Pharmacol, Suppl., London, v. 37, 83P, 1985.

2 - AMERONGEN, IA., RONDE, H.A.G., KLOOSTER, N.T.M. Physicalchemical characterization of semisolid topical dosage form using a new dissolution system. Int. J. Pharm., Amsterdam, v. 86, p. 9-15, 1992.

3 - ATTWOOD, D., COLLETT, J.H., TAIT, C.J. The micellar properties of the poly oxyethylene)- poly (oxypropylene) copolymer Pluronic F-127 in water and electrolyte olution. Int. J. Pharm, Amsterdam, v. 26, p. 25-33, 1985.

4 - BADRA, M.V.L., MAIA CAMPOS, P.M.B.G., RICCI, G. Estudo da influência de diferentes veículos cosméticos na liberą̧a e absorçáo do D-Pantenol: Avaliaçáo in vitro e in vivo. In: CONGRESO LATINO AMERICANO Y IBERICO DE QUIMICOS COSMETICOS, 11, 1993. Montevideo, Anais, p. 215-20.

S - BAE, Y.H., KIM, S.W. Hydrogel delivery systems based on polymer blends, block copolymers on interpenetrating networks. Adv. Drug. Del. Rev., Amsterdam, v. 11, n. 1-2, p. 109-35, 1993.

6 - BARRY, B.W. Dermatological Formulations. Percutaneous absorption. New York: Marcel Dekker, 1983, p. 1-233, 351- 407.

7 - BARRY, B.W. Transdermal drugs delivery. In: JOHNSON, P., LLOYD-JONES, J.G. Drug Delivery Systems (Fundamentals and Techniques). Chichester, Ellis Horwood, 1987, p. 200-23. 
8 - BARRY, B.W., BENNETT, S.L. Effect of penetration enhancers on the permeation of mannitol, hydrocortisone and progesterone through human skin. J. Pharm. Pharmacol, London, v. 39, p. 535-46, 1987.

9 - BENITA, S., HOFFMAN, A., DONBROW, M. Microencapsulation of paracetomal using polyacrylate resins (Eudragit Retard), kinetics of drug release and évaluation of kinetic model. J. Pharm. Pharmacol, London, v. 37, p. 391-5, 1985.

10 - BENNETT, S.L., BARRY, B.W. Effectiveness of skin penetration enhancers propylene glycol, azone, decylmethylsulphoxide and oleic acid with model polar (mamitol) and nompolar (hydrocortisone) penetrants. J. Pharm. Pharmacol., Suppl., London, v. 37, 84P, 1985.

11 - BOND, J.R, BARRY, B.W. Long term hydration effets on prmeability of hairless mouse skin. J. Pharm. Pharmacol, Suppl., London, v. 37, 77P, 1985.

12 - BOTTARI, F., DI COLO, G., NANNIPIERI, E., SAETTONE, M.F., SERAFINI, M.F. Release of drugs from ointment bases $\mathrm{I}$ : In vitro release of benzocaine from suspension - type aqueous gels. J. Pharm. Scl., Washington, v. 66, n. 7, p. 926-31, 1977.

13 - BRONAUGH, R.L., CONGDON, E.R, SCHEUPLEIN, R.J. The effect of cosmetic vehicles on the penetration of $\mathrm{N}$. nitrosodiethanolamine through excised human skin. J. Invest. Dermatol, New York, v. 76, n 2, p. 94-6, 1981.

14 - BRONAUGH, R.L., STEWART, R.F. Methods for in vitro percutaneous absorption studies III: Hydrophobic compounds. J. Pharm. Scl, Washington, v. 73, n. 9, p. 1255-8, 1984. 
15 - BROUNAUGH, R.L., STEWART, R.F., CONGDON, E.R. Methods for in vitro percutaneous absorption studies II Animal models for human skin. Toxicol. Appl. Pharmacol, New York, v. 62, p. 481-8, 1982.

16 - BRONAUGH, R., STEWART, R.F. Methods for in vitro percutaneous absorption studies IV: The flow-through diffusion cell. J. Pharm. Scl, Washington, v. 74, n. 1, p.64-7, 1985.

17 - BRONAUGH, RL., STEWART, R.F. Methods for in vitro percutaneous absorption studies VI: preparation of the barrier layer. J. Pharm. Scl, Washington, v. 75, n. 5, p. 487-091, 1986.

18 - BUSSE, M.J., HUNT, P., LEES, KA., MAGGS, P.N.D., McCARTHY, T.M. Release of betamethasone derivatives from ointments - in vivo and in vitro studies. $\mathrm{Br}$. J. Dermatol., Suppl., Oxford, v. 81, p. 103-12, 1969. (Supplement. 4).

19 - CAPPEL, M.J., KREUTER, J. Effect of nonionic surfactantes on transdermal drug delivery: I Polysorbates. Int. J. Pharm., Amsterdam, v. 69, p. 143-53, 1991.

20 - CHIANG, C.M., FLYNN, G.L., WEINER, N.D., SZPUNAR, G.J. Biogvailability assessment of topical delivery systems: effect of inter-subject variability on relative in vitro deliveries of minoxidil and hydrocortisone from solution and ointment formulations. Int. J. Pharm, Amsterdam, v. 50, p. 21-6, 1989.

21 - CHIEN, Y.W. Developmental concepts and practice in transdermal therapeutics systems. In: CHIEN, Y.W. Transdermal Controlled Systemic Medications. New York: Marcel Dekker, 1987, p. 25-81. 
22 - CHOW, D.S.L, KAKA, I, WANO, T.I Concentration-dependent enhancement of 1dodecylazacycloheptan-2-one, on the percutaneous penetration kinetics of triamcinolone acetonide. J. Pharm. Scl, Washington, v. 73, n. 12, p. 1794-9, 1984.

23 - CHOWHAN, ZT., PRITCHARD, R. Release of corticoids from oleaginous ointment bases containing drugs in suspension. J. Pharm. Scl., Washington, v. 64, n. 5, p. 754-9, 1975.

24 - COLDMAN, M.F., POULSEN, B.J., HIGUCHI, T. Enhancement of percutaneous absorption by the use of volatile: nonvolatile systems as vehicles. J. Pharm. Sci., Washington, v. 58, n. 9, p. 1098-102, 1969.

25 - COLLETT, J.H., TOBIN, E.A. Relationships between poloxamer structure and the solubilization of some para-substituted acetanilides. J. Pharm. Pharmacol, London, v. 1, p. $174-7,1979$.

26 - DELATTRE, L. Excipients et nouvelles formes topiques en dermatologie. J. Pharm. Bełg., Bruxelles, v. 48, n. 4, p. 261-9, 1993.

27 - DE VOS, F., DE MUYNCK, C., GEERTS, M., REMON, J.P. Percutaneous absorption of indomethacin from transparent oil/water gels in rabbits. J. Pharm. Pharmacol, London, v. 43, p. $237-41,1991$.

28 - DICIONÁRIO de Especialidades Farmacêuticas, 22ª ed, Rio de Janeiro, Editora de Publicą̧res Médicas, 1993/1994. 
29 - DI COLO, G., GIANNESSI C., NANNIPIERI, E., SERAFINI, M.F., VTTALE, D. Influence of drug-surfactant and skin-surfactantinteraction on percutaneous absorption of two model compounds from ointment bases in vitro. Int. J. Pharm., Amsterdam, v. 50, p. 27-34, 1989.

30 - DURRHEIM, H, FLYNN, G.L., HIGUCHI, W.I, BEHL, C.R Permeation of hairless mouse skin I: Experimental methods and comparasion with human epidermal permeation by alkanols. J. Pharm. Sci, Washington, v. 69, n. 7, p. 781- 6, 1980.

31 - ELIAS, P.M. The importance of epidermal lipids for the stratum comeum barrier. In: OSBORNE, D.W., AMANN, A.H. Topical drug delivery formulations. New York, Marcel Dekker, 1990, p. 13-28.

32 - FLYNN, G.L. Mechanism of percutaneous absorption from physicochemical evidence. In: BRONAUGH, RL., MAIBACH, HI Percutaneous Absorption (Mechanisms, Methodology, Drug Delivery), 2 ed, New York, Marcel Dekker, 1989, p. 37.

33 - FLYNN, G.L., DURRHEIM, H, HIGUCHI, W.I Permeation of hairless mouse skin II: Membrane sectioning techniques and influence on alkanol permeabilities. J. Pharm. Scl., Washington, v. 70, n. 1, p. 52-6, 1981.

34 - FRANZ, T.J. Percutaneous absorption. On the relevance of in vitro data. J. Invest. Dermatol., New York, v. 64, n. 3, p. 190-5, 1975.

35 - FULLERTON, D.S. Steroids and therapeutically related compounds. In: DOERGE, R.F. Wilson and Gisvold's Textbook of Organic Medicinal and Pharmaceutical Chemistry, 2 ed., New York, J.B. Lippincott Company, 1982, p. 657-732. 
36 - GAGNE', D., LODGE, B.A Analysis of dexamethasone sodium phosphate formulation by high-performance liquid chromatography. J. Chromatogr., Amsterdam, v. 193, p. 160-2, 1980.

37 - GASCO, M.R, GALLARTE, M., PAPTARINO, F. In vitro permeation of azelaic acid from viscosized microemulsions. Int. J. Pharm., Amsterdam, v. 69, p. 193-6, 1991.

38 - GASCO, M.R., GALLARATE, M., PATTARINO, F. On the release of prednisone from oil water microemulsions. II Farmaco, Pavia, v. 43, n. 10, p. 325-30, 1988.

39 - GASCO, M.R., TROTTA, M., CARLOTT, M.E. Effect of carboxylic acids on permeation of chlorpromazine through dimethyl polysiloxane membrane. J. Pharm. Sci., Washington, v. 71, n. 2, 239-41, 1982.

40 - GHOSH, T.K, CHIAO, C.S., GOKHALE, R.D. In vitro permeation of some B-blockers across the hairless mouse skin. J. Pharm. Pharmacol., London, v. 45, p. 218-9, 1993.

41 - GOODMAN, M., BARRY, B.W. Differential scamning calorimetry (DSC) of human stratum corneum: effect of azone. J. Pharm. Pharmacol., Suppl., London, v. 37, 80P, 1985.

42 - GUMMER, C.L., HINZ, R.S., MAIBACH, HI The skin penetration cell: a design update, Int. J. Pharm., Amsterdam, v. 40, p. 101-4, 1987.

43 - GUPTE, V.V., MATHESON, L.E. Permeation of small organic molecules through hairless mouse skin: correlation with flux through polydimethylsiloxgne (PDMS) membrane. Pharm. Res., Suppl., New York, v. 10, n. 10, PDD 7255, 1993. 
44 - GUY, R.H, HADGRAFT, J. Mathematical models of percutaneous absorption. In: BRONAUGH, R.L., MAIBACH, HI. Percutaneous Absorption (Mechanisms, Methodology, Drug Delivery), 2 ed., New York, Marcel Dekker, 1989, p. 13-26.

45 - GUY, R.H, HADGRAFT, J. On the determination of drug release rates from topical dosage forms. Int. J. Pharm., Amsterdam, v. 60, R1-R3, 1990.

46-HADGRAFT, J., ASHTON, P. The effect of sodium lauryl sulphate on topical drug availability. J. Pharm., Pharmacol., Suppl., London, v. 37, 85P, 1985.

47 - HADGRAFT, J., BEUTNER, D., WOLFF, HM. In vivo-in vitro comparisons in the transdermal delivery of nitroglycerin. Int. J. Pharm., Amsterdam, v. 89, R1-R4, 1993.

48 - HADGRAFT, J., RDOUT, G. Comparison between two in vitro methods for determining percutaneous absorption. J. Pharm. Pharmacol., Suppl., London, v. 37, 75P, 1985.

49 - HATANAKA, T., INUMA, M., SUGIBAYASHI, K, MORIMOTO, Y. Prediction of skin permeability of drugs. II Development of composite membrane as a skin alternative. Int. J. Pharm., Amsterdam, v. 79, p. 21-8, 1992.

50 - HOLLAND, J.M., KAO, J.Y., WHITAKER, M.J. A multisample apparatus for kinetic evaluation of skin penetration in vitro: the influence of viability and metabolic status of the skin. Toxicol. Appl. Pharmacol., New York, v. 72, p. 272-80, 1984.

51 - HOR, M., SATOH, S., MAIBACH, H.I Classification of percutaneous penetration enhancers: a conceptional diagram. J. Pharm. Pharmacol, London, v. 42, p. 71-2, 1990. 
52 - HORI, M., SATOH, S., MAIBACH, H.I., GUY, R.H. Enhancement of propranolol hydrochloride and diazepam skin absorption in vitro: effect of enhancer lipophilicity. J. Pharm. Scl., Washington, v. 80, n. 1, p. 32-5, 1991.

53 - HWANG, C.C., DANTI, A.G. Percutaneous absorption of flufenamic acid in rabbits: effect of dimethyl sulfoxide and various nonionic surface-active agents. J. Pharm. Scl., Washington, v. 72, n. 8, p. 857-60, 1983.

54 - IDSON, B. Percutaneous absorption. J. Pharm. Scl., Washington, v. 64, n. 6, p. 901-24, 1975.

55 - INFORMACION DE MEDICAMENTOS. USP. Di Edicion en Espaftol. Madrid, Ministerio de Sanidad y Consumo, 1989. p. 809-23.

56 - ISHII, F., SASAKI, I, OGATA, H. Effect of phospholipid emulsifiers on physicochemical properties of intravenous fat emulsions and/or drug carrier emulsions. J. Pharm. Pharmacol., London, v. 42, p. 513-5, 1990.

57 - KADIR, R, BARRY, B.W. a-Bisabolol, a possible safe penetration enhancer for dermal and transdermal therapeutics. Int. J. Pharm., Amsterdam, v. 70, p. 87-94, 1991.

58 - KADIR, R., BARRY, B.W., FAIRBROTHER, J.E., HOLLINGSBEE, D.A. Delivery of triamcinolone acetonide through human epidermis: effect of Actiderm, a new hydrocolloid dermatological patch Int. J. Pharm., Amsterdam, v. 60, p. 139-45, 1990.

59 - KNECZKE, M., LANDERSJO, L., LUNDGREN, P., FUHRER, C. In vitro release of salicyclic acid from two different qualities of white petrolatum Acta Pharm. Snec., Stockholm, v. 23, n. 4, p. 193-204, 1986. 
60 - KONTTURI, K, MURTOMĂI, K, HIRVONEN, J., PARONEN, P., URTTI, A Electrochemical characterization of human skin by impedance spectroscopy: the effect of penetration enhancers. Pharm. Res., New York, v. 10, n. 3, p. 381-5, 1993.

61 - KUBOTA, K, KOYAMA, E., TWIZELL, E.H. Dual sorption model for the nonlinear percutaneous permeation kinetics of timolol. J. Pharm. Sci., Washington, v. 82, n. 12, p. 1205-8, 1993.

62 - KUBOTA, K, MAIBACH, H.I In vitro percutaneous permeation of betamethasone and betamethasone 17-valerate. J. Pharm. Scl., Washington, v. 82, n. 10, p. 1039-45, 1993.

63 - KUBOTA, K, SZNTTOWSKA, M., MAIBACH, H.I Percutaneous absorption: a singlelayer model. J. Pharm. Scl., Washington, v. 82 n. 5, p. 450-6, 1993.

64 - KUROSAKI, Y., NAGAHARA, N., TANIZAWA, T., NISHIMURA, H. NAKAYAMA, R, KIMURA, T. Use of lipid disperse systems in transdermal drugs delivery: comparative study of flufenamic acid permeation among rat abdominal skin, silicon rubber membrane and stratum corneum sheet isolated from hamster cheek pouch. Int. J. Pharm., Amsterdam, v. 67, p. $1-9,1991$.

65 - MAIA CAMPOS, G. "G.M.C. software versão 6.6. Desenvolvido no Departamento de Estomatologia, da Faculdade de Odontologia de Ribeiráo Preto - USP.

66 - MAITANI, Y., COUTEL-EGROS, A, OBATA, Y., NAGAI, T. Prediction of skin permeabilities of diclofenac and propanolol from theoretical partition coefficients determined from cohesion parameters. J. Pharm. Sci., Washington, v. 82, n. 4, p. 416-20, 1993. 
67 - MARON, N., CRISTI, E.A., RAMOS, A.A. Determination of betamethasone 17-benzoate in lipophylic vehicles by reversed-phase high-performance liquid chromatography. J. Pharm. Scl., Washington, v. 77, n. 7, p. 638-9, 1988.

68 - MARTIN, A, BUSTAManTE, P., CHUN, A.H.C. Physical Pharmacy. Physical chemical principles in the pharmaceutical sciences. 4 ed. Philadelphia: Lea \& Febinger, 1993, p. 324-61, p. 556-94.

69 - MARTINDALE The extra Pharmacopoeia $30^{2}$ ed. London: The Pharmaceutical Press, 1993, p. $712-40$.

70 - MASNI, V., BONTE, F., MEYBECK, A., WEPIERRE, J. Cutaneous bioavailability on hairless rats of tretinoin in liposomes or gel. J. Pharm. Scl., Washington, v. 82, n. 1, p. 17 . $21,1993$.

71 - MICHNIAK, B.B., CHAPMAN, J.M., SEYDA, K.L. Facilitated transport of two model steroids by esters and amides of clofibric acid. J. Pharm. Scl., Washington, v. 82, n. 2, p. 214-19, 1993.

72 - MICHNLAK-MIKOLAJCZAK, B.B., BARRY, B.W. Water vapour sorption and desorption in human stratum corneum in vitro: effect of sodium chloride and urea. $\mathbf{J}$. Pharm. Pharmacol., Suppl., London, v. 37, 79P, 1985.

73 - MIREJOVSKY, D., TAKRURI, H Dermal penetration enhancement profile of hexamethylenelauramide and its homologues: in vitro versus in vivo behavior of enhancers in the penetration of hydrocortisone. J. Pharm. Scl, Washington, v. 75, n. 11, p. 1089-93, 1986. 
74 - MOES, AJ. La pénétration percutanée des médicaments. J. Pharm. Belg., Bruxelles, v. 48, n. 4, p. $252-60,1993$.

75 - MOLLGAARD, B., HOELGAARD, A Vehicle effect on topical drug delivery II Concurrent skin transport of drugs and vehicle components. Acta Pharm. Suec., Stockholm, v. 20, p. 443-50, 1983.

76 - MORIMOTO, K, FUKANOKI, S., HTAKEYAMA, Y., NAGAYASU, A, MORISAKA, K, HYON, S.H., IKADA, Y. Desing of a polyvinyl alcohol hydrogel containing phospholipid as controlled-release vehicle for rectal administration of $( \pm)$-propanolol HCl. J. Pharm. Pharmacol, London, v. 42, p. 720-2, 1990.

77 - MUNRO, D.D. The relationship between percutaneous absorption and statrum cormeum retention. Br. J. Dermatol., Suppl., Oxford, v. 81, p. 92-7, 1969. (Supplement 4).

78 - NEUBERT, R, BENDAS, C., WOHLRAB, W., GIENAU, B., FURST, W. A multilayer membrane system for modelling drug penetration into skin. Int. J. Pharm., Amsterdam, v. 75, p. 89-94, 1991.

79 - NEUBERT, R, WINTER, K, BENDAS, B. Bestimmung der Arzneistoffverfugbarkeit aus kommerziellen topischen Zubereitungen mit dem Mehrschichtmembranmodell. Pharmaxie, Frankfiurt/Main, v. 48, n. 1, p. 54-6, 1993.

80 - NIAZY, EM. Influence of oleic acid and other permeation promoters on transdermal delivery of dihydroergotamine through rabbit skin. Int. J. Pharm., Amsterdam, v. 67, p. 97. $100,1991$. 
81 - NIEMI, L, KAHELA, P., TURAKKA, L. Effect of water content and type of emulgator on the release of hydrocortisone from $O / W$ creams. Acta Pharm. Nordica, Stockholm, v. 1, $n$. 1,p. 23-30, 1989.

82 - OKAMOTO, H. HASHIDA, M., SEZAKE, H Effect of 1-alkyl- or 1alkenylazacycloalkanone derivatives on the penetration of drugs with differents lipophilicities through guinea pig skin. J. Pharm. Scl., Washington, v. 80, n. 1, p. 39-45, 1991.

83 - OLSZEWSKI, Z, KUBIS, A. Examination on the liberation process of active substances from ointment bases by means of the authors' construction apparatus. Acta Polon. Pharm., Warszawa, v. 26, n. 5, p. 440-9, 1969.

84 - ORR, N.A., HIL, E.A., SMTTH, J.F. Dosage uniformity in hydrocortisone ointment B.P. J. Pharm. Pharmacol, London, v. 32, p. 166-72, 1980.

85 - OSTRENGA, J., STEINMETZ, C., POULSEN, B. Significance of vehicle composition I: Relationship between topical vehicle composition, skin penetrability, and clinical efficacy. J. Pharm. Sci, Washington, v. 60, n. 8, p. 1175-9, 1971.

86 - PANCHAGNULA, R, RITSCHEL, W.A. Development and evaluation of an intracutaneous depot formulation of corticosteroids using Transcutol as a cosolvent: in vitro, ex vivo and in vivo rat studies. J. Pharm. Pharmacol, London, v. 43, p. 609-14, 1991.

87 - PEPPAS, N.A, KHARE, A.R. Preparation, structure and diffusional behavior of bydrogels in controlled release. Adv. Drug. Del. Rev., Amsterdam, v. 11, n. 1-2, p. 1-35, 1993. 
88 - PETERSEN, M.C., NATION, R.L., ASHIEY, J.J. Simultaneous determination of betamethasone, betamethasone acetate and hydrocortisone in biological fluids using highperformance liquid chromatography. J. Chromatogr., Amsterdam, v. 183, p. 131-9, 1980.

89 - PHARMACOPOEIA of The United States of America $22^{2}$ ed. Rockville: United States Pharmacopoeial Convention, 1990, p. 1578-83.

90 - POLANO, M.K., PONEC, M. Dependence of corticosteroid penetration on the vehicle. Arch. Dermatol., Chicago, v. 112, n. 5, p. 675-80, 1976.

91 - PRÍBORSKÝ, J., MÜHLBACHOVÁ, E. Evaluation of in vitro percutaneous absorption across human skin and in animal models. J. Pharm. Pharmacol., London, v. 42, p. 468- 72, 1990.

92 - RAYNAL, S., GROSSIORD, J.L, SEILLER, M., CLAUSSE, D. A topical W/O/W multiple emulsion containing several active substances: formulation, characterization and study of release. J. Controlled Release, Amsterdam, v. 26, n. 2, p. 129-40, 1993.

93 - REGNIER, M., CARON, D., REICHERT, U., SCHAEFER, H. Barrier function of human skin and human reconstructed epidermis. J. Pharm. Scl., Washington, v. 82, n. 4, p. 404-7, 1993.

94 - REIFENRATH, W.G., CHELLQUIST, E.M., SHIPWASH, E.A.,JEDERBERG, W.W., KRUEGER, G.G. Percutaneous penetration in the hairless dog, weanling pig an grafted athymic nude mouse: evaluation of models for predicting skin penetration in man. Br. J. Dermatol, Oxford, v. 27, p. 123-35, 1984. 
95 - REIFENRATH, W.G., HAWKINS, G.S., KURTZ, M.S. Percutaneous penetration and skin retention of topically applied compounds: an in vitro-in vivo study. J. Pharm. Scl., Washington, v. 80, n. 6, p. 526-31, 1991.

96 - ROLLAND, A, DEMICHELIPS, G., JAMDULE, J.C., SHROOT, B. Influence of formulation, receptor fluid, and occlusion, on in vitro drug release from topical dosage forms, using an automated flow-through diffusion cell. Pharm. Res., New York, v. 9, n. 1, p. 82-93, 1992.

97 - ROSE, J.P., JUSKO, W.J. Corticosteroid analysis in biological fluids by highperformance liquid chromatography. J. Chromatogr., Amsterdam, v. 162, p. 273-80, 1979.

98 - ROSSI, A.F., DASH, A.K Development and evaluation of a sustained release topical benzocaine formulations. Pharm. Res., Suppl., New York, v. 10, n. 10, PDD 7385, 1993.

99 - ROUGIER, A., DUPUIS, D., LOTTE, C., ROUGUET, R, SCHAEFER, H. In vivo correlation between stratum corneum reservoir function and percutaneous absorption. J. Invest. Dermatol., New York, v. 81, n. 3, p. 275-8, 1983.

100 - ROY, S.D., ROOS, E., SHARMA, K Transdermal delivery of buprenorphine through cadaver skin. J. Pharm Sci., Washington, v. 83, n. 2, p. 126-30, 1994.

101 - SARPOTDAR, P.P., ZATZ, J.L. Evaluation of penetration enhancement of lidocaine by anonionic surfactants through hairless mouse skin in vitro. J. Pharm. Scl., Washington, v. 75 , n. 2, p. 176-81, 1986. 
102 - SASAKI, H., KOJMA, M., MORI, Y., NAKAMURA, J., SHIBASAKI, J. Enhancing effect of pyrrolidone derivatives on transdermal penetration of 5-fluorouracil, triamcinolona acetonide, indomethacin, and flurbiprofen. J. Pharm. Scl, Washington, v. 80, n. 6, p. 533$8,1991$.

103 - SASAKI, H., KOJMA, M., NAKAMURA, J., SHIBASAKI, J. Enhancing effect of combining two pyrrolidone vehicles on transdermal drug delivery. J. Pharm. Pharmacol., London, v. 42, p. 196-9, 1990.

104 - SATO, K, SUGIBAYASHI, K, MORIMOTO, Y. Species differences in percutaneous absorption of nicoradil. J. Pharm. Scl., Washington, v. 80, n. 2, p. 104-7, 1991.

105 - SCHEUPIEEN, R.J., BLANK, IH, BRAUNER, G.J., MacFARLANE, D.J. Percutaneous absorption of steroids. J. Invest. Dermatol. New York, v. S2, n. 1, p. 63-70, 1969.

106 - SCHUMANN, R. In vitro absorption of butylated hydroxyanisole through human skin. J. Soc. Cosmet. Chem, New York, v. 42, n. 5, p. 335-40, 1991.

107 - SCOGGINS, R.B., KLIMAN, B. Percutaneous absorption of corticosteroides. New Engl. J. Med., Boston, v. 273, n. 16, p. 831-40, 1965.

108 - SCOTT, R.C., RAMSEY, J.D. Comparison of the in vivo and in vitro percutaneous absorption of a lipophilic molecule (Cypermethrin, a pyrethroid insecticide). J. Invest. Dermatol, New York, v. 89, n. 2, p. 412-6, 1987.

109 - SCOTT, R.C., WALKER, M., DUGARD, P.H. In vitro percutaneous absorption experiments: a technique for the production of intact epidermal membranes from rat skin. $J$. Soc. Cosmet. Chem., New York, v. 37, n. 1, p. 35-41, 1986. 
110 - SETHI, P.K., AGHA, B.J. In vitro human cadaver skin retention and penetration of a lipophilic compound. Pharm. Res., Suppl., New York, v. 10, n. 10, PDD 7309, 1993.

111 - SHAH, J.C. Analysis of permeation data: evaluation of the lag time method. Int. J. Pharm., Amsterdam, v. 90, p. 161-9, 1993.

112 - SHAH, V.P., BEHL, C.R, FLYNN, G.L., HIGUCHI, W.I., SCHAEFER, H., Principles and criteria in the development and optimization of topical therapeutic products. Int. J. Pharm., Amsterdam, v. 82, p. 21-8, 1992.

113 - SHAH, V.P., ELKNS, J., SKELLY, J.P. Relationship between in vivo skin blanching and in vitro release rate for betamethasone valerate creams. J. Pharm. Scl., Washington, v. 81, n. 1 , p. $104-6,1992$.

114 - SHAH, V.P., SKEILY, J.P. Regulatory considerations in transdermal drug delivery systems in the United States. In: CHIEN, Y.W. Transdermal Controlled Systemic Medications. New York: Marcel Dekker, 1987, p. 399-417.

115 - SHAHI, V., ZATZ, J.L. Effect of formulation factors on penetration of hydrocortisone through mouse skin. J. Pharm. Sci., Washington, v. 67, n. 6, p. 789-92, 1978.

116 - SHAW, M.C., VANDERWIELEN, A.J. Liquid chromatographic assay for diflorasone diacetate in cream and ointment formulations. J. Pharm. Sci., Washington, v. 73, n. 11, p. 1606-8, 1984.

117 - SMID-KORBAR, J., KRISTL, J., SRCIC, S. Wirkstoff-Freisetsung aus Dermatica Pharmazie, Berlin, v. 37, n. 5, p. 363-5, 1982. 
118 - SMITH, E.W., HAJGH, J.M. In vitro systems for assessment of drug release from topical formulations and transmembrane permeation. In: BRONAUGH, R.L., MAIBACH, H.I Percutaneous Absorption (Mechanisms, Methodology, Drug Delivery), 2 ed, New York, Marcel Dekker, 1989, p. 465-508.

119 - STUPAR, M., VULETA, G., PRIMORAC, M. Comparative examination of the release of the salicylic acid from microemulsive gel and excipiens lanacoli aquosum Pharmazie, Berlin, v. 41, n 7, p. 514, 1986.

120 - SURBER, C., WILHELM, K.P., MAIBACH, HI In vitro skin pharmacokinetics of acitretin: percutaneous absorption studies in intact and modified skin from three different species using different receptor solutions. J. Pharm. Pharmacol., London, v. 43, p. 836$40,1991$.

121 - TANAKA, S., TAKASHIMA, Y., MURAYAMA, H., TSUCHIYA, S. Solubility and distribution of dexamethasone acetate in oil-in-water creams and its release from the creams. Chem. Pharm. Bull., Tokio, v. 33, n. 9, p. 3929-34, 1985.

122 - TAUBER, U., TODA, T. Biotransformation von Diflucortolon-valerianat in der Haut von Ratte, Meerschweinchen und Mensch. Arzneim-Forsch. (Drug. Res.), Aulendorf, v. 26, $n$. 7 b, p. 1484-7, 1976.

123 - TENJARLA, S.N., HOLBROOK, J.H Imitation potential of various akin penetration enhancers. Pharm. Res., Suppl., New York, v. 10, n. 10, PDD 7264, 1993.

124 - TOJO, K. Design and calibration of in vitro permeation apparatus. In: CHIEN, Y.W. Transdeamal Controlled Systemic Medications. New York: Marcel Dekker, 1987, p. 127-58. 
125 - TOKUNAGA, H., KIMURA, T., KAWAMURA, J. Determination of glucocorticoids by liquid chromatography. III Application to ointments and a cream containing cortisone acetate, dexametasone acetate, fluorometholone, and betamethasone valerate. Chem. Pharm. Bull., Tokio, v. 32, n. 10, p. 4012-6, 1984.

126 - TOMDA, H, SHINOHARA, M., KUWADA, N., KIRYU, S. In vitro release characteristics of diclofenac and hydrocortisone from Pluronic F-127 gels. Acta Pharm. Suec., Stockhlom, v. 24, p. 263-72, 1987.

127 - TOOTHAKER, R.D., SUNDARESAN, G.M., HUNT, J.P., GOEHL, T.J., ROTENBERG, K.S., PRASAD, V.K., GRAIG, W.A., WELLING, P.G. Oral hydrocortisone pharmacokinetics: a comparison of fluorescence and ultraviolet high-pressure liquid chromatographic assays for hydrocortisone in plasma J. Pharm. Sci., Washington, v. 71, n. 5, p. $573-6,1992$.

128 - TORUAN-PURBA, A., TABIBI, E., MENDES, R. Isotretinoin liposomes with soluble collagen as a penetration enhancer through shed snake skin Pharm. Res., Suppl., New York, v. 10, n. 10, PDD 7277, 1993.

129 - TURAKKA, L., KONTRA, K, KYLLONEN, AM. Release of hydroxybenzoic acids from a triglyceride vehicle containing sufactantes. Pharm Acta Helv., Zurich, v. 58, n. 56, p. $153-9,1983$.

130 - UJ, K, TAKAHASHI, K, HEMKER, W. The properties of lecithin and lecithin-liposome containing emulsions, emulsified with cross linked acrylic acid-alkil acrylate crosspolymer. In: INTERNATIONAL CONGRESS YOKOHAMA, 17, 1992. Yokohama, Anais. Koyohama: International Federation. Societies Cosmetic Chemists, 1992, v. 1, p. 69-86. 
131 - WESTER, R.C., MAIBACH, HI In vitro testing of topical pharmaceutical formulations. In: BRONAUGH, R.L., MAIBACH, H.I. Percutaneous absorption (Mechanisms, Methodology, Drug Delivery), 2 ed, New York, Marcel Dekker, 1989, p. 653-9.

132 - WESTER, R.C., MAIBACH, HI Relationship of topical dose and percutaneous absorption in Rhesus monkey and man. J. Invest. Dermatol., New York, v. 67, n. 4, p. 518-20, 1976.

133 - WILIIAMS, A.C., BARRY, B.W. Snake skin as a model for human skin in permeation studies; molecular evaluation by raman spectroscopy. Pharm. Res., Suppl., New York, v. 10, n 10, PDD 7259, 1993.

134 - YAMASHTTA, F., BANDO, H, KOYAMA, Y., KITAGAWA, S., TAKAKURA, Y., HASHIDA, M., In Vivo ana in vitro analysis of skin penetration enhacement based on a two-layer diffusion model with polar and nonpolar routes in the stratum corneum. Pharm. Res., New York, v. 11, n. 2, p. 185-91, 1994.

De acordo com a norma NBR 6023/89 preconizada pela Associą̧̃o Brasileira de Normas Técnicas (ABNT). As abreviaturas dos titulos de periódicos seguem o Chemical Abstracts Service Source Index (CASSI), 1990. 
9 - RESUMO 
Os corticosteróides sto substância largamente empregadas em dertatologia devido ao seu potente efeito anti-inflamatório na pela. Entretanto, associado a este efeito benéfico tem-se o risco da ocorre̊ncia de efeitos colaterais, decorrentes principalmente da absorçåo sistêmica dos corticosteróides pela via cutanea

A penetrą̧ão transcutânea e retenção cutânea dos corticosteróides é influenciada pelo veiculo no qual estes princípios ativos são incorporados. Assim sendo, os objetivos desta pesquisa forạm investigar, in vitro, formulą̧ðes que proporcionassem uma alta retençåo cutânea dos corticosteróides na pele e também mínima penetração transcutânea

O estudo foi realizado com geis de Poloxamer 407 contendo diferentes concentrą̧бes dos promotores de absorção cutânea, uréia ou lecitina Os parâmetros liberação, penetraçáo transcutanea e retençấo cutânea dos acetatos de hidrocortisona e dexametasona, desonida e triamcinolona acetonida foram avaliados por metodologia in vitro, utilizando-se de célula de difusấo e membranas.

A quantificação dos corticosteróides nas diferentes fases do experimento foi realizada por cromatografia líquida de alta eficiência.

Os resultados obtidos mostraram a influência do vef́culo nos parametros avaliados. As formulações obedeceram cinética de 1 a ordem para a liberaça e penetraçáo transcutânea

As preparaços contendo lecitina promoveram uma maior retençáo cutanea dos corticosteróides, sugerindo, assim, que géis de Poloxamer 407, associados com lecitina, formam veículos adequados para a incorporafáo de corticosterbides. 
10 - SUMMARY 
Corticoids are drugs often used in dermatology due to its anti-inflamatory effect in the skin. Meanwhile, together with this beneficial effect it can have side effects, due to the systemic absorption of the corticoids by cutaneous way.

Transcutaneous penetration and cutaneous retention of the corticoids is influenciated by the vehicle in which this drugs are incorporated. In this way, the objetive of this research was to investigate, in vitro, formulations that would provide both, high cutaneous retention of the corticoids in the skin and minimum transcutaneous penetration.

For this work was used Poloxamer 407 gels containing different concentrations of the absorptions enhancers, urea and lecithin. The release transcutaneous penetration and cutaneous retention of hydrocortisone and dexamethasone acetate, desonide and triamcinolone acetonide was evaluated by in vitro methodology using diffusion cells and membranes. The corticoids was analysed by HPLC.

The results obtained showed the influence of the vehicle in the evaluated parameters.

The corticoid release and transcutaneous penetration appeared to fit first order kinetic.

The formulations containing lecithin promoved higher cutaneous retetion of the corticoids than the containing urea, sugesting, in this way, that Poloxamer 407 gels in the presence of lecithin are adequated preparations to the corticoids. 